6. DERECHOS DEL AUTOR Y PROPIEDAD INTELECTUAL APUNTES DE UN DEBATE

ANDRES OLLERO TASSARA

Catedrático de Filosofía del Derecho Universidad de Granada 
Revista de Derecho Político, núm. 27-28, 1988, pp. 113-180

\title{
6. DERECHOS DEL AUTOR Y PROPIEDAD INTELECTUAL. APUNTES DE UN DEBATE
}

\author{
POR \\ ANDRES OLLERO TASSARA \\ Catedrático de Filosofia del Derecho \\ Universidad Granada
}

La sustitución de una ley centenaria no es, ciertamente, acontecimiento habitual. Sólo una notable sintonía con las directrices llamadas a protagonizar el futuro de los derechos del autor, y la habilidad para diseñar fórmulas de gran capacidad de adaptación ', hicieron posible la insólita vigencia de la Ley de Propiedad Intelectual de 10 de enero de 1879. Aunque, cumplidos sus setenta años, algunos consideraban todavía deseable que su reforma fuera «mínima, limitándose a una mera revisión», con mucha anterioridad había comenzado a ser tachada de «a todas luces arcaica por los que proponian la necesidad de una amplia reforma ${ }^{2}$.

No han faltado en lo que va de siglo proyectos que aspiraran a sucederla, ampliamente superados en número por las Comisiones creadas

1 La Memoria del Proyecto de ley de Propiedad Intelectual, al ilustrar el inicio de su trámite, resaltaba en el primer párrafo de su Introducción «el admirable sentido común" de los autores de la ley centenaria y su acierto al extender su aplicación a las obras que se creen "por cualquier medio conocido o por conocer».

2 Por una parte, el Primer Congreso Nacional de Bibliotecarios, Archiveros y Arqueólogos, celebrado en 1950, en la primera de las conclusiones de su sección sexta, por otra la orden de 7 de octubre de 1938, que constituye una Comisión para su reforma: cfr. C. Alvarez Romero La Constitución española y el derecho de propiedad intelectual "Boletin de la ANABAD» 1979(1), p. 79. El proyecto de ley de 27 de junio de 1934 había llegado ya al Congreso, donde se presentó al día siguiente: cfr. Propiedad Intelectual Madrid, Congreso de los Diputados, Documentación n. 46, febrero 1986, pp. 167 y 393 ss. 
al efecto ${ }^{3}$. Tres factores justifican, una y otra vez, lo inaplazable de la reforma: el cambio de enfoque experimentado en la concepción de la «propiedad intelectual", la necesidad de plasmar en textos legales los compromisos internacionales asumidos paulatinamente, y la entrada en juego de problemas inéditos, de la mano del creciente avance tecnológico ${ }^{4}$. Pero la transformación experimentada por la «propiedad intelectual» no ha sido, entre nosotros, mera consecuencia del paso del tiempo. La Constitución de 1978 llevaba consigo una auténtica refundamentación de nuestro ordenamiento jurídico, que no ha dejado de influir notablemente en este ámbito. De ello nos ocuparemos primordialmente en estos apuntes.

Los documentos internacionales van surgiendo ante la necesidad de garantizar a los autores el disfrute de sus derechos más allá de las fronteras de su país. Es el intento del Convenio de Berna de 9 de septiembre de 1886, cuyos posteriores complementos y revisiones le han llevado a protagonizar el juego internacional de estos derechos ${ }^{5}$. Pero, junto a este afán de superar las fronteras nacionales, surgen otro tipo de documentos con mayor hondura. Así la Declaración Universal de los Derechos Humanos reconoce en su artículo 27.2 tal rango al «derecho (de toda persona) a la protección de los intereses morales y materiales que le correspondan por razón de las producciones científicas, literarias o artísticas de que sea autora». A este documento, de 1948, seguirá en 1966 el Pacto Internacional de Derechos Económicos, Sociales y Culturales que, en su artículo 15.1.c reconoce el derecho a "beneficiarse de la protección de los intereses morales y materiales" aludidos. Del empeño por hacer más amplio y eficaz el

3 El citado trabajo de C. Alvarez Romero, que formó parte de la Comisión creada en 1966, completado por el de P. MiserachS SALAS -Acotaciones históricas a la reforma de la Ley de la Propiedad Intelectual «La Ley» 1985(2), pp. 1007 y ss.- ayudan a trazar una amplia sucesión de Comisiones, borradores y proyectos. En 1908 la Asociación de la Libreria Española encarga un proyecto, cuyo ponente considera anticuada la ley. No tuvo más éxito que el que encargara la Conferencia Nacional del Libro, ultimado en 1928. Tras el ya citado de 1934, se suceden en la postguerra nuevas comisiones. El Instituto Nacional del Libro Español elabora proyectos en 1945 y 1956. En 1963 el Ministerio de Información y Turismo deja varado otro que debía haberse promulgado a la vez que la Ley de Prensa e Imprenta. La Comisión creada por Orden de 28 de febrero de 1966, siendo ministro Lora Tamayo, deja tras cerca de cien reuniones un anteproyecto casi ultimado. J. M. CHIco ORTIZ -Principios y problemas de la propiedad intelectual "Revista de Derecho Inmobiliario» 1984(565) p. 1.322 - informa con detalle de otra comisión de la que fue miembro, creada en 1979, cuyo trabajo se plasmaria en 1981 en un anteproyecto, siendo ministro de Cultura Pío Cabanillas. La Comisión de 1983 se amplió, dando paso a un anteproyecto en 1984; un grupo de trabajo de 1985 última el proyecto -cfr. Memoria... (nota 1) p. 3- que se publica al fin en el «Boletín Oficial de las Cortes Generales» (BOCG) el 1 de febrero de 1986, con el n. 184-1 de la Serie A.

${ }_{4}$ Ya el proyecto de 27 de junio de 1934 aludia al cambio de concepciones operado, a la necesidad de adecuar el Registro a las previsiones del Convenio de Berna y a la regulación del gramótono, la radio y el cine —Propiedad intelectual (nota 2), p. 394.

5 Fue completada en París en 1986, revisado en Berlín en 1908, completado en Berna en 1914, revisado en Roma en 1928 reconociendo internacionalmente el "derecho moral" de los autores, y revisado de nuevo en Bruselas en 1948; al respecto A. MISERACHS RIGALT Sistemas internacionales para la protección de los derechos españoles de autor "Revista Jurídica de Cataluña" 1981(3) p. 105. 
ámbito de reconocimiento de unos derechos se ha pasado, pues, a su reconocimiento como derechos personales del máximo rango. En el lapso entre estos dos documentos se gesta bajo los auspicios de la UNESCO, la Convención Universal de Ginebra de $1952^{6}$, que aspira a complementar la Unión de Berna mediante un convenio menos riguroso, capaz de implicar a paises que como Estados Unidos, no habían llegado a adherirse.

Protección efectiva de los derechos del autor y reconocimiento de su carácter fundamental marcan dos puntos de una decisiva evolución que no deja de encontrar reflejo en el ámbito constitucional comparado. En unos casos, mediante una tarea jurisprudencial que precisa el alcance del texto originario. Asi ocurre en Alemania Federal, cuya Ley Fundamental proclama que «la ciencia y su doctrina son libres»; lo que se configuraba como garantía institucional, la jurisprudencia lo ha desarrollado posteriormente reconociendo rango fundamental a los derechos del autor ${ }^{7}$. Constituciones más recientes, como la portuguesa en su artículo 42 , han incorporado ya en su texto esta dimensión, sintonizando con la vía evolutiva señalada. La española de 1978, más por desaliño que por discrepancia de nuestros constituyentes, nos lega una situación de ambigüedad de la que tendremos ocasión de ocuparnos.

Nuestra Constitución aporta, por otra parte, nuevos elementos a este cuadro de influencias. Asume, en efecto, en el propio ordenamiento los tratados internacionales, cuya fuerza vinculante habia regularizado la reforma del Título Preliminar del Código Civil. Se subsanaba así la anómala situación creada al no verse reflejados con rango legal los documentos internacionales suscritos con posterioridad a la ley de 1879. A la vez, la alusión del artículo 10.2 al juego interpretativo de los documentos internacionales sobre derechos humanos confiere a los pasajes arriba expuestos una particular relevancia, que no cabe ignorar a la hora de establecer el rango de los derechos del autor en nuestro ordenamiento jurídico.

Por último, los notables avances tecnológicos encuentran reflejo en el proyecto definitivo de reforma a través de la presión de diversos grupos profesionales afectados. El afán pragmático por poner de acuerdo a los diversos colectivos implicados pudo más en este caso que la preocupación

- Complementará en España el sistema de protección de Berna; cfr. A. MiserachS Rigalt Sistemas... (nota 5), pp. 120 y ss. Tras el Acta de Estocolmo de 1967, que sólo afectaba a la Unión de Berna, se realiza convocatoria conjunta con los países adheridos a la Convención de Ginebra, surgiendo las Actas de París de 1971, en vigor en España desde 1974 -lbidem pp. 106-107.

Al respecto J. M. OTERo LASTRES La protección constitucional del derecho de autor: análisis del artículo 20.1.b de la Constitución española de 1978 «La Ley» 30 de abril de 1986(1.442), p. $2 c^{\star}$ y 3a. No faltan alusiones a la doctrina alemana en la Demanda - pp. 18b y 19a- presentada ante el Tribunal Constitucional el 9 de enero de 1986 por E. GARCIA DE ENTERRIA solicitando amparo en nombre de la viuda del escultor Pablo Serrano.

*Identificamos con $a, b, c .$. bien aquellas fuentes en las que el texto está compuesto en varias columnas, o bien los documentos procesales presentados en pliegos de doble folio. 
por plasmar con rigor los perfiles básicos de los derechos en juego. Los defensores del proyecto no dejaron de recordar, con toda justicia, su notable esfuerzo de receptividad y conciliación de intereses ${ }^{8}$. Como es fácil imaginar, no se llegó a contentar a todos, con lo que las presiones se mantienen a lo largo del debate, a través de enmiendas asumidas, en ocasiones de modo textual, por Grupos parlamentarios de la ideología más dispar; circunstancia ésta que, de modo paradójico, resaltaria ahora peyorativamente el Grupo mayoritario ${ }^{9}$.

Este empeño por contar con el apoyo -o al menos el visto buenode los principales afectados por la ley cuyo fácil acceso a los medios de comunicación no fuera desdeñable, hereda una pauta de prudencia política ejercida ya en la lejana elaboración del texto legal precedente ${ }^{10}$. Por otra parte, la disolución anticipada de las Cámaras restó a la Segunda Legislatura siete meses, que habrian bastado para finalizar el trámite del proyecto. Interrumpido apenas emitido el informe de la Ponencia, el debate resulta enriquecido por un doble factor. Si al proyecto publicado el 1 de febrero de $1986{ }^{11}$ se presentaron 186 enmiendas, de las que la Ponencia recogió $77^{12}$, el nuevo proyecto — publicado el 24 de noviembre- ${ }^{13}$ no sólo ve ampliadas a 387 las enmiendas al artículado sino que contaría también, a diferencia del anterior, con dos enmiendas la totalidad; una de ellas mantenida hasta hacer posible que el debate llegara por vez primera a plantearse ante el Pleno del Congreso. Esta misma ampliación del debate contribuirá a poner de manifiesto lo engañoso del consenso aparentemente alcanzado, si se da más importancia a los problemas jurídicos planteados que al mero logro pragmático de unos resultados ventajosos a corto

- El ministro SolanA, al presentar el proyecto ante el Pleno del Congreso, cifra en más de veinticinco los sectores consultados - Cortes Generales. Diario de Sesiones del Congreso de los Diputados (CG-DSC) III Legislatura, Pleno y Diputación Permanente n. 30 de 12 de febrero de 1987 (en adelante $P$-30), p. 1703b. Ya antes la Comisión de Educación y Universidades, Investigación y Cultura del Senado había emitido un Dictamen, tras comparecer ante ella diecinueve expertos - Cortes Generales. Diario de Sesiones del Senado (CG-DSS) I/ Legislatura Serie I, n. 152 de 14 de mayo de 1985 -incluído en Propiedad Intelectual (nota 2), cuya paginación citaremos en adelante. El senador socialista BARRAL AGESTA no dejó de evocarlo al iniciarse el debate del proyecto ante el Pleno del Senado CG-DSS. III Legis/atura n. 46 de 7 de octubre de 1987 (en adelante S-46) p. 1.756a y $1.757 \mathrm{~b}$.

- Se subrayó con frecuencia la identidad de enmiendas de los grupos de Izquierda Unida y Minoría Catalana, aunque esa se limitara a mantenerlas sin intervenir prácticamente en el debate; por ello fue el portavoz de IU quien resultó más de una vez ilustrado sobre la procedencia de sus propias enmiendas -cfr., por ejemplo, CG-DSC. III Legis/atura. Comisiones n. 128 de 12 de mayo de 1987 (en adelante C-128) pp. 4.835a y 4.865b.

10 J. M. CHICO ORTIZ —Principios... (nota 3) p. 1.348- señala entre sus autores a «músicos, novelistas, pintores y poetas, dirigidos jurídicamente por Danvila». M. DANVILA Y COLLADO plasmó sus experiencias en Propiedad intelectual. Legislación española y extranjera Madrid 1882.

1 BOCG-CD, II Legislatura, Serie A, n. 184-1.

12 Así lo recuerda el ministro SolANA ante el Pleno - P-30 (nota 8), p. $1.703 \mathrm{~b}$.

13 BOCG-CD, III Legislatura, Serie A, n. 14-1. 
plazo ${ }^{14}$. La urgencia por contar cuanto antes con una nueva ley, capaz de colmar inevitables lagunas o imprevisiones sobrevenidas al texto precedente, se habia antepuesto al interés por alcanzar las soluciones más rigurosas a problemas cuya incidencia práctica sólo cabe vislumbrar desde perspectivas primordiales juridicas.

La participación personal en el debate ${ }^{15}$, nos ha facilitado una peculiar riqueza de información, por más que pueda verse acompañada por una posible pérdida de perspectiva al valorar aspectos concretos. Podemos, no obstante, aventurar como primera impresión que, mientras las reivindicaciones en juego fueron contempladas con notable celo, hasta prestar al texto en más de una ocasión una agobiante prolijidad ${ }^{16}$, los problemas jurídicos básicos, que la doctrina lleva décadas discutiendo, parecen haber sido tenidos en cuenta sólo lo indispensable para eludirlos cuidadosamente. Especialmente Ilamativa resulta esta querencia evasiva cuando se trata de cuestiones incoadas por un texto constitucional que aún no ha cumplido los diez años. Si en la intervención de los Diputados de la mayoria ello podria achacarse a la bibliografía manejada ${ }^{77}$, la actitud de la Memoria explicativa del proyecto, su Exposición de Motivos y el propio articulado traslucen una estrategia de mayor alcance sobre cuya intención será obligado volver.

\section{UNA «PROPIEDAD» CON PECULIARES PROPIEDADES}

Las vicisitudes planteadas en el transcurso de un siglo por el recurso al término "propiedad intelectual" podrian servir de expresivo test sobre la delicada relación entre dogmática jurídica y realidad social. Figuras o esquemas conceptuales que, en un determinado momento, se muestran

14 No eran pocos los contenciosos pendientes, de monto económico nada despreciable, que los afectados se veian obligados a solventar «al abordaje jurídico» - P-30 (nota 8 ), p. $1.705 a$.

${ }_{15}$ Para su preparación me resultaron de inestimable ayuda los textos y sugerencias de dos Profesores de la Facultad de Derecho granadina que estaban ultimando extensos y documentados estudios sobre los aspectos civiles - G. Orozco PARDO- y penales $-C$. CARMONA SALGADO_** de la propiedad intelectual. A ambos debo especial reconocimiento por aportaciones que han dejado, sin duda, también huella en este trabajo.

"Manual de Derecho de Autor Granada, en prensa.

* La nueva Ley de propiedad intelectual, Madrid, 1988.

${ }^{16}$ J. M. Chico ORTiz —Principios... (nota 3) pp. 1.330 y 1352- prevé "serios conflictos en el momento de su aplicación», debido a «un afán excesivamente definitorio", que no impide que conceptos como los de piratería o reprografía no hayan sido suficientemente matizados.

17 En efecto, el diputado socialista Del Pozo I Alvarez, sin duda el más documentado de su grupo, citó con profusión a $H$. Baylos Corroza - cfr., por ejemplo, C-128 (nota 9) pp. $4.809 \mathrm{~b}$ y $4.823 \mathrm{~b}$ - cuyo voluminoso Tratado de Derecho industrial, propiedad industrial, propiedad intelectual, Derecho de la competencia económica, y Disciplina de la competencia desleal - Madrid 1978- es anterior a la Constitución, por lo que ignora obligadamente las cuestiones que la interpretacion y desarrollo de su texto, ha ido suscitando. 
como instrumentos oportunos para el logro de ese ajuste teleológico que da sentido al derecho pueden convertirse, con el paso del tiempo, en el obstáculo más eficaz para garantizar dicha finalidad. Empeñarse, en tal tesitura, en rendir culto al concepto puede llevar a un sacrificio de expectativas sociales, con los desajustes consiguientes. Algo de esto puede haber ocurrido con la catalogación como «propiedad» del nucleo fundamental de los «derechos del autor».

Los autores se vieron obligados a luchar en su día contra una visión «platónica» de su labor (el arte por amor al arte...). Sus primeros logros no llegaron a ver convertidas sus pretensiones de rendimiento económico en «derechos», sino que tuvieron que conformarse con la concesión de privilegios que les reconocieran el monopolio de la impresión y difusión de sus obras. Pero un «privilegio" es concesión excepcional de problemática continuidad; convertirlo en "derecho" hace cambiar decididamente el centro de gravedad de la relación jurídica; porque lo que era concesión graciosa se transmuta en exigencia de obligado reconocimiento. Configurar tal "derecho» como propiedad aportaba por entonces una doble ventaja: emparentar con una figura de raigambre iusnaturalista, merecedora del más sólido fundamento jurídico ${ }^{18}$, y aspirar - como consecuencia- a su disfrute perpetuo ${ }^{19}$, al abrigo de humores o coyunturas. Precisamente el difícil reconocimiento de esa duración ilimitada - primero como obstáculo a la fluidez del mercado ${ }^{20}$ y más tarde por consideraciones de interés social- será una de las peculiares propiedades de tan peculiar «propiedad".

Con el paso del tiempo se ha ido poniendo de relive el costo de este empeño por presentar los derechos del autor como si constituyeran una variedad peculiar del derecho de propiedad. Sufren los derechos del autor,

18 El propio Preámbulo con que Danvila presenta "A las Cortes» la proposición de la ley de 1879 recuerda a la «propiedad literaria» «envuelta al nacer en la temerosa palabra del privilegio", aunque ya en 1764 «se concedio la transmisión indefinida». Equiparada la propiedad intelectual a la común, «elevando esta teoría a la categoria de ley, quedará asegurada la libertad de pensamientos - Propiedad intelectual (nota 2), pp. 335a y 337b; también $346 a$.

19 DANVILA señala que, en el paso del privilegio al derecho, la «gloria estaba reservada a Carlos III que, siguiendo los patrióticos consejos de Jovellanos y Floridablanca, se anticipó a su época». Una Real Orden de 20 de octubre de 1764 sería «la primera disposición legislativa española que reconoce el derecho de propiedad literaria". La ley publicada en Cádiz el 22 de julio de 1823 equipara plenamente a la propiedad intelectual con la común, pero no llegó a producir efectos ni a insertarse en la “Colección Legislativa». El art. $2 .^{\circ}$ de la proposición de ley de 1879 precisaba que «la propiedad intelectual se rige por el mismo derecho regulador de las demás propiedades, y como éstas es perpetua...", frase esta que desaparece en el Dictamen de la Comisión que lo convierte en artículo $5 .^{\circ}$. En el Senado, la alusión al «derecho regulador de las demás propiedades" se ve sustituida por una referencia al «derecho común" que se convertirá en texto definitivo -Propiedad intelectual (nota 2), pp. 335b, 336, 341b, 351a, $367 \mathrm{~b}$ y $388 \mathrm{~b}$.

${ }_{20}$ Fue el conflicto entre la pretensión monopolística de los creadores y la ideología revolucionaria defensora del libre mercado lo que aconsejó, "con fines polemicos y políticos», optar por la propiedad como figura jurídica más ventajosa-H. BAYLos Corroza, Tratado... (nota 17), p. 401. 
al serles de aplicación - al menos supletoria ${ }^{21}$ - los principios y normas básicas de la institución; sufre la propiedad misma, al verse obligada a acoger en su seno una realidad bastante alejada de las que le dan sentido.

Este afán por superar una concepción forzadamente platónica de la actividad creativa se vio con el tiempo sustituído por otro de signo diverso: ahora el peligro era reducir tales derechos al cobro de determinados porcentajes de la explotación de la obra artística, dando paso a una «mercenaria concepción del autor» ${ }^{22}$. Caracteristica al respecto es la emergencia de los llamados "derechos morales", cuyo encaje en el marco de la propiedad exige más imaginación aún que el cambio de tan curiosa terminología.

Desde el prisma de la propiedad, suponen una especie de atípica hipoteca, que no sólo legitima determinadas exigencias del autor sobre una obra cuya venta ya fue consumada, sino que coloca en incómoda situación al que creyó adquirirla por compra: no podrá abandonar o destruir el objeto comprado ${ }^{23}$, se verá obligado a conservarlo tan celosamente como si lo tuviera en depósito ${ }^{24}$, no podrá reproducirlo o exponerlo a su gusto y antojo ${ }^{25}$, y deberá compartir - siquiera mínimamente- sus ganancias si

21 El artículo 429 del Código Civil de 24 de julio de 1889 señala, respecto a la propiedad intelectual, que "en casos no previstos ni resueltos por dicha ley especial se aplicarán las reglas generales establecidas en este Código sobre la propiedad". El proyecto de 27 de junio de 1934 incluía, entre las disposiciones complementarias, como derecho supletorio el Convenio de Berna u otros y también «las disposiciones del Código Civil que afecten a la propiedad" - Propiedad inteloctual (nota 2), p. 401b.

22 En gráfica expresión de la Memoria... del proyecto - (nota 1), p. 5-, objeto de reiterada cita en el debate - por ejemplo, P-30 (nota 8), p. 1.705a. Como consecuencia de este planteamiento, la identificación entre derechos del autor y propiedad intelectual los reduciria a su dimensión patrimonial; incluso la expresión derechos "del» autor, al convertirse en derechos "de" autor, acaba cobrando análogo significado restringido. Ya el proyecto de 1934, tras hacer consistir en su artículo $1 .^{\circ}$ la propiedad intelectual de una obra en la posibilidad de «publicarla, venderla, explotarla y autorizar su explotación», señala en el artículo 2. que esta facultad, netamente patrimonial, es "llamada "Derecho de Autor" " -Propiedad intelectual (nota 2), p. 395a. La dimensión ambivalente de esta expresión se pone de relieve en la Orden de 22 de febrero de 1965 o en el Decreto 3.028/78 de 10 de noviembre, que aprueban los estatutos de la Sociedad General de Autores de España -ibidem, pp. 239 y $289 a$.

${ }_{23}$ Pese a que constituya "una de las facultades del dominio», según recuerda J. G. STORCH DE GRACIA Y ASENSIO - Derecho a la producción y creación intelectual, derecho de autor y derecho de propiedad sobre la obra concreta. Reflexiones para una construcción jurídica de estos derechos «la Ley» 1986(2), p. 1.180b-citando la sentencia del Tribunal Supremo (1. $\left.{ }^{a}\right)$ del 21 de junio de 1965, que pone fin a la primera etapa del caso Pablo Serrano.

24 Lo que supone imponerle un "derecho de servidumbre de custodia», a juicio de N. PÉREZ de CASTRO - El derecho de propiedad sobre obras de arte y el derecho del autor al respeto de la obra “Actualidad Civil» 1987(4) p. 232- que señala (p. 221) "la existencia de una serie de facultades que son extrañas al concepto de propiedad".

${ }^{25}$ Lo que «extiende las facultades del autor hasta limites que me parecen excesivos" -E. Serrano Alonso Sugerencias para una reforma del derecho de autor "Actualidad Civil" 1986(2), p. 74; “si se reafirma este derecho del autor frente al propietario, hay que reconocer que la titularidad adquirida está vacía de verdadero contenidow (p. 75). 
lo revende en pública subasta ${ }^{26}$. Todos estos detalles son tan lógicos, si se aprecia la creacion artística más allá de las rutinas del mercado, como ininteligibles, si se toma a la propiedad tan en serio como los civilistas suelen tener por costumbre ${ }^{27}$.

Complicaciones no menores para el autor derivan de este disfraz de sus derechos como «propiedad». Aparte de aspectos de mayor cuantía, a los que aludimos más abajo, resulta ser un propietario que no puede transferir la titularidad indefinida de su derecho ${ }^{28}$, puede experimentar las consecuencias de una aplicación forzada del régimen de comunidad de bienes, si colabora con otros ${ }^{29}$, o puede ver sometido el nacimiento de sus derechos a requisitos registrales ${ }^{30}$.

26 Este «derecho de continuidad" (el "droit de suite» francés) lleva a reconocer al autor, que ya vendio, un «dominio eminente" o "propiedad retenida" sobre su obra, según señala N. PÉREz SERRANo - El derecho moral de los autores "Anuario de Derecho Civil» 1949(Il1), p. 27-, quien, aun reconociendo las "finalidades tan nobles como justas" de tales derechos, teme que puedan dar paso a cinfidelidades contractuales" o “constante inseguridad jurídica", lo que aconsejaría indemnizaciones que opongan tasa a "demasias, caprichos" e incumplimientos. De «dominio residual» y "propiedad residual» se hablará en el voto particular del magistrado A. FERNANDEZ RodRiguez - Fundamentos tercero y cuarto- a la sentencia a que nos referimos en la nota siguiente.

${ }_{27}$ Se ignora con todo ello un principio básico: el comprador adquiere un «derecho de propiedad, sólo limitable por la ley o la voluntad de las partes"; principio que la sentencia del Tribunal Supremo Sala Primera de 9 de diciembre de 1985, que cierra la segunda etapa del caso Pablo Serrano, considera en vigor por falta de desarrollo legal del Convenio de Berna. Texto y comentario sobre esta sentencia, a la que forzosamente volveremos a aludir, en $S$. Ortiz Navacerrada y X. O'Callaghan Muñoz, Sentencia del T.S. de 9 de diciembre de 1955 , sobre derecho moral de autor (Escultura de Pablo Serrano): notas sobre su temática procesal y civil "Actualidad Civil" 1986(9), pp. 593-614; el pasaje aludido: p. 597.

${ }_{28}$ Se lo impide la obligada reversión al dominio público, transcurrido un plazo «post mortem», por razones de interés social; «argumento que no me parece convincente, pues hay otras actividades del mismo o superior interés que, sin embargo, no están sometidas a tal restricción" - E. SERRANo Alonso, Sugerencias... (nota 25), p. 77-; o exigen al menos un trámite expropiatorio -J. M. Chico Ortiz, Principios... (nota 3), p. 1.345. Por si fuera poco, la ley de 1879 , en su artículo $6 .^{\circ}$, consideraba extinguida la transmisión a los veinticinco años del fallecimiento para que revirtiera a los herederos forzosos, antes de hacerlo -a los ochenta- al dominio público.

29 Por logico que ello sea, pueden producirse problemas si no se jerarquizan los derechos en juego - cfr. E. Serrano Alonso, Sugerencias... (nota 25), pp. 66-67-, aparte de la imposible aplicación de dicho criterio a los «derechos morales». Este último fue contemplado en la enmienda $n .^{\circ} 139$ al artículo 7 del proyecto, - BOCG-CD Serie A, $n .{ }^{\circ} 14-7$ de 22 de abril de 1987-, aunque, al no asumirse en el resto del articulado la identificación entre "propiedad intelectual» y meros derechos de explotación, su intención resultó desvirtuada.

${ }^{30}$ Se ha ido imponiendo, por influjo de los convenios internacionales, la adquisición del derecho por la mera creación de la obra; esto supondría "un nuevo modo originario de adquisición del dominio" - C. Alvarez Romero, La Constitución... (nota 2), p. 80-, por más que la inscripción en el Registro pueda haber servido ade instrumento para el ingreso vergonzante y anticipado de las obras en el dominio público", (p. 84). Se ha rechazado que la inscripción tuviera carácter constitutivo, pues sólo seria relevante a la hora de hacer efectiva la protección de los derechos, sin perjuicio de su posible sancionatario, como señala uno de los titulares del Registro, J. M. CHICO ORTIz Presente y futuro de la propiedad intelectual «Boletin de la ANABAD» 1979(1), pp. 17 y 24 ; insiste en ello en Principios... (nota 3), pp. 1.343 y 1.349 . 
Estos intentos de reconducir la realidad social de los derechos del autor a las categorias dogmáticas de la propiedad producen un continuo chirriar. Su misma configuración como «propiedad especial» los sitúa al borde mismo del ámbito civil, en problemática vecindad con el administrativo ${ }^{31}$; se les volvería a considerar asi, regresivamente, como concesiones administrativas, eliminando la ventaja principal que la sustitución del "privilegio" por la "propiedad" había aportado. Sus caracteres provocan una continua serie de anomalías respecto a los perfiles básicos de la propiedad: no tienen por objeto una cosa determinada, tienden a imponer una obligación de no hacer, su querencia a un disfrute monopolítico contrasta con la libre concurrencia que anima la propiedad común... ${ }^{32}$.

Ante esta elocuente realidad caben tres posturas. La que defienden algunos civilistas poco dados a la metáfora, que proponen la recondución estricta de los derechos del autor a los esquemas de la propiedad común ${ }^{33}$. Otra, más imaginativa, que aspira a reiventar la propiedad, para que los derechos del autor puedan habitar cómodamente en su seno; tendríamos así que "la propiedad patrimonial o económica es una derivación de una propiedad más profunda, que es la estrictamente intelectual o moral", aunque para fundamentarla haya que superar con aplomo las fronteras de la física: "nadie debe avergonzarse de atribuir el concepto de propiedad a los bienes espirituales o morales, por cuanto la propiedad, antes que una institución jurídica, es también una cualidad metafísica que implica unicidad y atribución perenne de una cualidad a un sujeto» ${ }^{34}$. Pero resta aún una tercera posibilidad, a la que venían animando los documentos y convenios internacionales: emancipar a los derechos del autor, cuyo núcleo básico tendría rango fundamental, del incómodo marco de la propiedad común, en un momento histórico en el que el carácter fundamental de ésta se halla en entredicho.

31 Al respecto $\mathrm{H}$. BAYLos -Tratado... (nota 17), pp. 407 y $605-$, que considera que "debe abandonarse totalmente" la configuración de los derechos del autor como "figuras intermedias o híbridas", ya que son “de carácter privado".

32 El propio H. BAYLOS - Tratado... (nota 17), pp. 412 a 414- que, en su esfuerzo por delimitarlos conceptualmente, los caracteriza como "derechos absolutos" dotados de un "carácter remisivo peculiar", ya que su objeto no sería la creación misma sino "un facere regido por ella» (pp. 597 y 598).

${ }_{33}$ Especialmente tajante al respecto el ya citado E. SERRANo Alonso, que considera "abusivo" el juego de los llamados «derechos morales" sobre la obra enajenada, y entiende por ello "que la orientación aconsejable es precisamente la opuesta a la que se deduce de la actual ordenación»; de ahí su opción por el término "derecho de propiedad del autor», mediando en la polémica entre "propiedad intelectual" y "derechos del autor" - Sugerencias... (nota 25), pp. 72 y 58 .

${ }_{34}$ El diputado socialista Del Pozo en el debate del articulado - C-128 (nota 9), pp. 4.807 b y $4.808 \mathrm{a}$ - apoyándose en la expresión «intereses morales» de los Pactos Internacionales y en planteamientos de G. PECES BARBA, a los que tendremos ocasión de aludir. La perspectiva civilista lleva, por el contrario, a metalizar lo más inmaterial; así J. G. STORCH -Derecho a la producción... (nota 23), p. 1.179a considera que el «bien inmaterial» objeto del derecho del autor consiste «en la utilidad»(sic) que a su titular reportan tanto la explotación como el respeto a la paternidad de la obra o la persecución del plagio. 
Ya metidos en distingos terminológicos, no será ocioso indicar -antes de seguir adelante - la forzada sustitución del término «derechos del autor» por el rótulo «derechos de autor». Construcción tan poco castellana puede deberse al influjo de figuras extranjeras que, faltas de una actualización legislativa capaz de asimilarlas, han campado por sus respetos por nuestra doctrina y nuestra práctica jurídicas. No hay duda, sin embargo, que tan forzada expresión se ha consolidado entre nosotros con una dimensión patrimonialista, que evoca fundamentalmente la cuota de participación la explotación de una obra. La necesidad de superar tan estrecho ángulo de visión nos llevará a reiterar en este trabajo la expresión «derechos del autor», no carente por demás de respaldo internacional ${ }^{35}$. Pero volvamos al hilo de nuestro discurso...

\section{¿Propiedad intelectual o derechos del autor?}

Examinando en perspectiva histórica, el término «propiedad intelectual» ocupa un lugar de enlace entre el originario de «propiedad literaria», que pronto mostraría su insuficiencia ${ }^{36}$, o el menos usual de upropiedad artística» ${ }^{37}$ y el hoy predominante "derechos del autor", que se ha consolidado en el ámbito internacional, dejando a la vez su huella en el largo proceso español de intentos de reforma ${ }^{38}$.

35 N.PéRez SerRANo recuerda cómo la confrontación entre la denominación francesa - «propiedad literaria y artística»- y la alemana — "derecho de autor»- que puso en peligro la gestación del Convenio de Berna de 1886, fue resuelta «merced a una fórmula híbrida e ingeniosa" que aludía a la "protección de los derechos de los autores" - El derecho moral... (nota 26), p. 8. Por su parte, P. MISERACHS SALA anima a incorporar "las orientaciones o principios básicos o rectores del Convenio de Berna, abandonando necesariamente el concepto español de la propiedad intelectual enraizada en la propiedad común" -Acotaciones... (nota 3), p. 1.010a.

36 La ley española de 10 de junio de 1847 hablaba de «propiedad literaria», término que se mantiene durante años en Reales Ordenes, aun a costa de referirse forzadamente, como la de 22 de marzo de 1850, a los que aspiren a «publicar en escultura". Después de la ley de 10 de enero de 1879 - presentada bajo la rúbrica "propiedad literaria» y aprobada con la de «propiedad intelectual»- aquél término sigue manteniendo vigencia durante años; así lo demuestra su empleo como sinónimo de propiedad intelectual en los Reales Decretos de 11 de junio de 1866, 6 de julio de 1894 y 31 de enero de 1896 -cfr. Propiedad intelectual (nota 2) pp. 55 y ss., sobre todo $63,105,113$ y 115 .

${ }_{37}$ De «propiedad artística" se habla, por ejemplo, en los resultantes de la sentencia del Tribunal Supremo de 21 de junio de 1965; igualmente E. GARCIA DE ENTERRIA, refiriéndose a etapas posteriores del caso Pablo Serrano, ve en él emplazada cpropiedad artística frente a propiedad física" - Pablo Serrano y el derecho moral del autor "ABC" 12 de abril de 1987, p. $32 \mathrm{a}$.

38 Si la apelación a la «propiedad intelectual» de la Conferencia Internacional de Roma (1928) lleva a N. PÉrez SERRANO, en 1949, a considerar que «lo más prudente ha de ser respetar la terminología allí establecida" - El derecho moral... (nota 26), p. 8-, hoy habría que hacer lo propio ante la consolidación del término "derechos del autor»-al respecto A. DIETZ, El derecho de autor en la Comunidad europea, Madrid 1983, t. I, p. 54. En el ámbito internacional, 
En esta tesitura apenas resta un argumento para mantener como eje central tal concepto: la arraigada «tradición» ${ }^{39}$ que la aplicación y estudio de tan veterana ley había conferido. Se incurre así en un curioso círculo vicioso; se desaprovecha una clara oportunidad de archivar, o al menos relegar a segundo plano, una terminología considerada unánimemente desafortunada ${ }^{40}$ apelando como argumento a la extremada duración de su inadecuado empleo. Pensamos, por el contrario, que al igual que se está de acuerdo en la necesidad de subordinar los encuadres dogmáticos y conceptuales al logro eficaz de un ajuste de relaciones sociales, abandonando toda «jurisprudencia de conceptos», resulta también obligado - aunque parezca una ardua empresa - evitar que la inercia linguística comprometa mejores resultados. La única réplica a esta actitud parece reservada a la consideración, superficial, de que nos hallamos ante meros juegos de palabras sin consecuencias prácticas ${ }^{41}$.

El transfondo del problema es bastante más hondo. Por una parte, la entrada en juego de los llamados derechos morales parece denunciar

aunque basta repasar las reseñas de legislación extranjera para advertir tal predominio, la Ley tipo de Túnez sobre el Derecho de Autor, elaborada entre el 23 de febrero y el 2 de marzo de 1976, con la participación de la OMPI y de la UNESCO, es suficientemente significativa -cfr. Propiedad intelectual (nota 2) t. II passim y especialmente pp. 1.389 y ss. Esto resta fuerza al argumento con que el senador socialista BAYONA concluye lapidariamente su intervención sobre el particular $-S-46$ (nota 8), p. 1.762a. En el ámbito español, ya la ley de 10 de junio de 1847 dedicaba el primero de sus tres Títulos a los «derechos de los autores". Van menudeando luego las referencias a los autores a partir de la Orden de 6 de enero de 1933, o a los aderechos de autor" (Orden Circular de 25 de mayo de 1936 y Orden de 17 de junio de 1937), considerados como sinónimos de la expresión legal (Decreto de 1 de febrero de 1952 sobre estatutos de la SGAE) —ibidem t. I, pp. 337 b y 157 ss. Por otra parte, el anteproyecto elaborado en 1963 llevaba como título "Ley sobre el derecho de autor" y el Decreto 3.096 de 1973 de 14 de septiembre incluye en el artículo 534 del Código Penal las uinfracciones del derecho de autor".

39 "Cuando cien años de nombre nos contemplan parece poco serio cambiar» -J. M. Chico Ortiz, Presente y futuro... (nota 30), p. 20. En el debate el diputado Del Pozo (PSOE) opta por dar "satisfacción a la propia tradición", mientras que HuIDoBro DIEz (AP) concede que «el título de propiedad intelectual puede discutirse, pero tiene arraigo en nuestra tradición»-C-128 (nota 9), pp. 4.808a y 4.811a.

${ }_{40}$ Llamativa resulta la actitud de $\mathrm{H}$. BAYLos que, resaltando la capacidad de supervivencia del término y su fuerza expresiva instrumental, aconseja aprovechar la tradición legislativa de su uso, aunque haciéndola «compatible con la adopción de una posición doctrinal de la naturaleza juridica de estas instituciones, que no sea la del derecho de propiedad" -Tratado... (nota 17), pp. 397, 415 y 74. Basta, sin embargo, atender a la jurisprudencia de los últimos veinte años, no ha llegado a ser suficientemente asimilado.

${ }_{41}$ Así el portavoz socialista en el debate de totalidad ante el Pleno del Congreso, Ballesteros DURAN, piensa que la discrepancia afectaba a "la denominación de muchos artículos y libros y no a la. esencia fundamental, al espiritu del proyecto"; no obstante, poco después - con sinceridad tan insólita como honrosa admite que se trata de «temas que escapan a mi preparación - lo confieso asi- porque yo no soy especialista en derecho"

$P-30$ (nota 8 ), pp. 1.709 a y 1.710 b. Tampoco el portavoz de AP, HuidoBRo, sintoniza con lo que considera «disquisiciones filosóficas y terminológicas", poco antes de aludir a una circunstancia quizá relevante: el proyecto comenzo ya su trámite en la Legislatura anterior sin que su Grupo planteara tales cuestiones, ni considerara necesario suscitar un debate de totalidad (p. 1.719b). 
que los derechos del autor van más allá de un derecho de propiedad, entendido con el alcance estrictamente patrimonial que un mínimo rigor exige. Ser autor llevaría consigo derechos de alcance aún mayor que el mero aprovechamiento de unas posibilidades de explotación, nada despreciables sin duda. El marco de la propiedad resulta estrecho al profundizarse en la honda dimension personal que la creatividad lleva consigo. Pero, por otra parte, la misma evolución sufrida por el derecho de propiedad a lo largo de un siglo viene a reforzar este fenómeno. A la propiedad se le atribuye hoy menor relevancia a la hora de enumerar las exigencias de la dignidad personal, a la vez que es su función social la que se convierte en fundamento básico de su legitimidad.

Hace un siglo la propiedad aparecía como un «derecho innato», «inherente al ser humano", que "abarca las facultades que constituyen su ser; es el elemento que completa su personalidad» $y$ “es el desenvolvimiento necesario de la libertad; sin la propiedad sería nulo el poder" ${ }^{42}$. Se trataba de afirmaciones destinadas a encontrar entonces fácil asentimiento; el esfuerzo argumental habia que reservarlo para resaltar que la «propiedad intelectual» era tan «sagrada como toda propiedad», e incluso condición de la legitimidad de cualquier otra ${ }^{43}$. Hoy, por el contrario, la propiedad ha dejado de identificarse con la libertad -entendida como propiedad de sí para cobrar un sentido instrumental, al servicio de una promoción de condiciones o eliminación de obstáculos que haga más real y efectiva no sólo la libertad sino también la igualdad ${ }^{44}$. Podriamos, pues, señalar que al crecimiento de la relevancia de los derechos del autor se une un decrecimiento de la del derecho de propiedad, que no hace sino reforzar idéntico fenómeno: la insuficiencia de la segunda como marco de referencia de los primeros.

Esta falta de correspondencia entre ambos conceptos jurídicos aconseja el archivo del término propiedad intelectual. Cabe, no obstante, si la apelación a la «tradición» resulta perentoria, otra actitud: reflejar con toda

42 Asi hablaba DANVILA, al presentar ante el Congreso la proposición de ley de 1879 -Propiedad intelectual (nota 2), p. 334a. Sobre estos planteamientos resulta de interés el estudio sobre El derecho moral de autor en el Proyecto de Ley de Propiedad Intelectual - "Análisis e Investigaciones Culturales" 1986(28) pp. 91-102- de D. Espin CANOvas, al que se concederia en diciembre de 1987 la Medalla de Oro de las Bellas Artes «por su especial contribución a la Ley de Propiedad Intelectual». Resulta Ilamativo, sin embargo, que, señalando el paso de una «concepción decinomónica» basada en la propiedad a «la época actual», que sitúa el centro de gravedad en los derechos de los autores -ibidem, p. 93a-, no llegaran a derivarse de ello consecuencias en el texto legal del que fue mentor.

${ }^{43}$ La cita corresponde al Real Decreto de 11 de junio de 1886. DanVILA, años antes, habia citado a CoLMEIRO: «suprimid la propiedad literaria y ahogaréis el germen de mil pensamientos que no se desarrollan por falta de estímulo»e incluso, a fin de cuentas, «habrá ganado su causa el comunismo»; negar la propiedad literaria equivaldría a «destruir los cimientos de toda clase de propiedad"-Propiedad intelectual (nota 2) pp. 105, 339b y 334b.

44 Concepción recogida en el artículo 9,2 de nuestra Constitución y presente también el reciente debate $-P-30$ (nota 8 ), p. 1.705a. 
nitidez la transformación acaecida, pasando a primer plano el término «derechos del autor", con la amplitud que recibe al albergar los «derechos morales», y reservar el de «propiedad intelectual» para referirse a los aspectos patrimoniales vinculados a la explotación de sus obras ${ }^{45}$.

Por paradójico que resulte, todo esto llevó a los mentores del proyecto a afirmar todo lo contrario: «se ha utilizado la denominación de(sic) "propiedad intelectual"», por considerarla "más ajustada a una realidad en la que convergen relaciones e intereses que desbordan, constantemente, el limitado marco conceptual del derecho del autor " ${ }^{46}$. Para entender tan sorprendente afirmación hay que dar paso a un nuevo factor, que añade complejidad al problema. Si los derechos morales parecen certificar la limitación e insuficiencia del término "propiedad intelectual», hay otros derechos - los llamados conexos o afines- que permiten beneficiarse de la explotación de una obra de la que no se es autor, porque se haya intervenido de algún modo en su publicación o difusión. Habría, por tanto, una propiedad intelectual situada fuera del marco conceptual de los derechos del autor, que - desde esta perspectiva- aparecen a su vez como limitados e insuficientes, o incluso como uno de los ingredientes de un género más amplio: la «propiedad intelectual» ${ }^{47}$.

Este aparente círculo vicioso sólo es soluble precisando cuál es el auténtico centro de gravedad de este conjunto de problemas. Si lo es la creatividad del autor, está claro que éste contará con unos "derechos" de diverso orden: unos personales o «morales» y otros patrimoniales, a los que cabría —en aras de la «tradición»- seguir calificando como «propiedad intelectual», a costa de asumir las complicaciones que ello llevara consigo. Que otras personas, sin ser creadores de su obra, puedan compartir con el autor alguno de sus derechos sobre ella no supone obstáculo alguno

45 Esta postura, planteada sin éxito en el debate $\longrightarrow$ - -128 (nota 9) p. 4.810 no supone ninguna audaz novedad. El propio N. Pérez Serrano no dejaba de distinguir el llamado "derecho moral» y un derecho patrimonial, que "es un verdadero derecho de propiedad" $-E I$ derecho moral... (nota 26), p. 22. Por su parte el Dictamen elaborada por la Comisión del Senado (nota 8) propone como primera recomendación: «la complejidad de los derechos de autor aconseja que las leyes hagan siempre a la vez inequivoca referencia a los Derechos de Autor y a la Propiedad Intelectual", para afirmar luego que "las leyes deben establecer la identidad del origen de los derechos patrimoniales y personales que constituyen el Derecho de Autor"; el mismo título del dictamen mantiene tal duplicidad de términos, aunque en el texto predomina claramente el primero -Propiedad intelectual (nota 2), pp. 409 y 403 . El senador socialista BARRAL acabará capitulando a la hora del debate, abandonando tan prometedora trayectoria $-S-46$ (nota 8), p. 1.757b.

46 Memoria del proyecto... (nota 1), p. 2

47 Así el diputado de AP HuIDOBRo admite que «la propiedad intelectual comprende los derechos del autor propiamente dichos y otros derechos, que se conocen en la doctrina con el nombre de derechos conexos o derechos afines" C-128 (nota 9), p. 4.810b. En idéntica línea, fiel a su planteamiento patrimonialista, E. Serrano Alonso Sugerencias... (nota 25), p. 58- propone como expresión más correcta "derecho de propiedad del autor". El senador socialista BARRAL levanta acta, a su vez, del batiburrillo terminológico resultante $-S-46$ (nota 8), p. $1.757 a$. 
para el reconocimiento del protagonismo que al autor corresponde en este ámbito jurídico ${ }^{48}$. Si, por el contrario, nos mantenemos aferrados a la vieja idea de la "propiedad intelectual" como propiedad especial, tan titulares serían los autores como los que se mezclan de modo «afín» o "conexo» en la explotación de su obra, facilitando su explotación y compartiendo sus rendimientos; siendo lo patrimonial el centro de gravedad, los derechos "morales" que protegen la dimensión personal de la creatividad del autor, se convierten en un elemento anómalo y asimétrico, que quizá sería más coherente abandonar a su suerte...

\section{Derechos “Morales»}

La doctrina se ha esforzado por disponer para los derechos del autor una acogida hospitalaria dentro de los marcos conceptuales consolidados. Lo ha hecho, sin duda, convencida de la relevancia práctica de su propia labor. La tarea no ha sido nada fácil. Los problemas comenzaron -causados quizá por una malformación congénita- a la hora de bautizar a la criatura; seguirán luego al intentar establecer si se ha asistido a un parto único o múltiple, con notable disenso entre «monistas» $y$ «dualistas», y todo ello abocará a la polémica sobre si cabe o no concederles la etiqueta de "derecho de la personalidad», destinada a emparentar - de manera más o menos pacífica - con otras que recibirian en su día refrendo constitucional.

Los llamados «derechos morales» protagonizan bien pronto todo este intento de encuadre jurídico. Su mismo nombre resulta insatisfactorio. No faltan quienes insinúan socarronamente que con ellos nacerían, «a sensu contrario", una muchedumbre de derechos «inmorales" ${ }^{49}$. También se señalará que tal denominación, consolidada fuera de nuestras fronteras con el apoyo de documentos internacionales, tiene en nuestra cultura jurídica connotaciones distintas e incluso opuestas a las que justificaron su uso ${ }^{50}$. Por el momento, ninguna otra denominación ha logrado en la práctica sustituirla, aunque algunas ${ }^{51}$ le acompañen.

45 El diputado socialista DeL Pozo, coherente con su esquema terminológico, se ve obligado a conceder que «la propiedad intelectual nace primaria y exclusivamente en el autor y que la participación de otros sujetos en ella es una participación extensiva o por desarrollo" $-C-128$ (nota 9), p. 4.811 b.

49 Asi N. Perez Serrano - El derecho moral... (nota 26), p. 7- o E. Serrano Alonso -Sugerencias... (nota 25), p. 58.

so En el debate pude apuntar como el término «moral», aplicado a derechos $u$ obligaciones, tiene entre nosotros “un matiz de debilidad, de elemento prejuridico o inmaduro", mientras que en la tradición anglosajona se alude bajo tal rótulo a unos derechos previos y más fundamentados que los meros derechos subjetivos $-P-30$ (nota 8 ), p. $4.823 \mathrm{a}$. El mentor de la ley reconoce que el término es «discutido", aunque «tiene la ventaja de estar hace tiempo 
La enumeración del contenido atribuible a este tipo de derechos aporta una idea bastante expresiva del desbordamiento de la «propiedad" como marco de referencia. Habría que incluir dimensiones positivas de la paternidad intelectual, como el derecho a crear una obra; el derecho a publicarla, o a evitar que llegue a ser conocida (derécho al inédito); el derecho a modificarla o destruirla, a continuarla y terminarla; a establecer que su publicación se haga con el propio nombre, bajo seudónimo o de forma anónima; el derecho a elegir los intérpretes que la harán llegar al espectador o el derecho a retirarla del comercio (derecho de arrepentimiento). Será preciso añadir otra vertiente destinada a garantizar el respeto a la obra, conservando su integridad y su título, impidiendo que se omita el nombre o no se respete el anónimo, impidiendo su publicación o reproducción imperfecta ${ }^{52}$...

Entre los caracteres que se les atribuyen como definitorios estarian su carácter absoluto, «erga omnes», su falta de dimensión patrimonial, el ser, inalienables, intransmisibles, imprescriptibles ${ }^{53}$, aunque no faltan los matices y excepciones. Especialmente delicada es la frontera con los derechos patrimoniales. No sólo porque nada impide que la lesión de dere-

consagrado, no sólo en la doctrina sino en el derecho comparado» -D. EsPIN CANOVAS, EI derecho moral... (nota 42), p. $96 \mathrm{~b}$.

51 La expresión derechos «personales" del autor encontraria en el debate menos eco del que permiten esperar los elementos disponibles: en la Conferencia Internacional de Roma (1928), que consolidó el término, la delegación italiana propuso el reconocimiento del derecho "moral" o "personal" del autor —cfr. N. Pérez SeraAno, El derecho moral... (nota 26), p. 12-; es frecuente que la doctrina los emplee como sinónimos - por ejemplo, P. Miserachs SaLA Acotaciones... (nota 3), p. 1.007b o N. PÉREz DE CASTRO -El derecho de propiedad... (nota 24), p. 221. La misma Memoria del proyecto... (nota 1), p. 5- señala cómo en éste cal lado de los derechos patrimoniales se mencionan expresamente una serie de derechos personales, irrenunciables e inalienables». El diputado socialista BALLESTEROS fue aún más claro, al resaltar ante el Pleno que el proyecto «reconoce no solamente derechos patrimoniales sino también derechos personales o morales» - P-30 (nota 8), p. 1.710b. Pese a todo, la enmienda que proponia hablar de derechos personales en vez de "morales" seria rechazada expeditivamente, citando a BAYLOS "autor de un Tratado de mucha solvencia" - C-128 (nota 9), p. 4.823b. En el Senado el socialista BARRAL manejará ambos términos como sinonimos, sin mayores consecuencias $-S-46$ (nota 8 ), p. $1.757 \mathrm{~b}$.

52 Al respecto P. MISERACHS SALA La propiedad intelectual en España en el primer centenario del Convenio de Berna, «Revista General de Derecho" 1986(504), p. 4.267. El proyecto de 1934 ya aludía en su articulo 19 al "derecho moral del autor", señalando que lo conserva aunque ceda los "derechos patrimoniales"; los concretaba en: reivindicar la paternidad de la obra, oponerse a su deformación, mutilación o modificación, y admitía su vigencia "post morten" - cfr. Propiedad intelectual (nota 2), p. 396a. En el debate de totalidad de la nueva ley el ministro SolANA resaltó su atención a los "derechos morales del autor, que por primera vez se recogen en nuestro ordenamiento jurídico", aludiendo en concreto al reconocimiento de la paternidad de la obra, al respeto a su integridad y al derecho de arrepentimiento -P-30 (nota 8), p. $1.702 \mathrm{~b}$.

53 Asi, N. Pérez Serrano, El derecho moral... (nota 26), pp. 22-23. H. Baylos, intentando lograr un denominador común al contenido de la propiedad intelectual y al de la industrial, remite a.los «derechos sobre prototipos normativos» -Tratado... (nota 17), p. 593. 
chos morales dé lugar a una indemnización pecuniaria, sino también por el complejo encaje de algunos de los derechos citados. Así el de publicación exclusiva puede plasmarse en una dimensión meramente patrimonial, como la que suele atribuirse al sistema anglosajón del copyright ${ }^{54}$. También al derecho de arrepentimiento se le ha reducido en más de una ocasión a un estrecho carácter patrimonial, que desvirtúa su alcance ${ }^{55}$, sin perjuicio de las indemnizaciones a que su ejercicio pueda dar lugar. Particularmente anómalo resulta el reconocimiento práctico de la duración de estos derechos, esforzándose los documentos internacionales ${ }^{56}$ por lograr una vigencia "post mortem» de alcance similar, al menos, a la de los derechos patrimoniales.

Si bien el proyecto sometido a debate no deja de contemplar estos "derechos morales", respondiendo así a las expectativas existentes, es más dudoso que los convierta en su "centro de gravedad" 57 .

\section{Entre monismo, dualismo... y paleomonismo}

Ya señalamos cómo la tenaz polémica entre «monistas» y «dualistas" es uno de los puntos clave de la elaboración dogmática de los derechos del autor. Sólo recordando la notable evolución sufrida — desde su enfoque como propiedad especial a su consideración como derecho fundamental cabe entender una discusión que, por momentos, amenaza con convertirse en puramente bizantina. Junto a ese factor histórico resalta, sin embargo, la doble presión a que la doctrina se ve sometida, según intente una cons-

54 J. M. Chico Ortiz, Principios... (nota 3), p. 1.342.

55 N. Pérez Serrano, recuerda las vacilaciones de la doctrina italiana sobre el particular -El derecho moral... (nota 26), p. 21. C. Alvarez Romero, resalta cómo la ley de 1879 sólo lo reconocia al autor propietario, y no al que hubiera transmitido sus derechos patrimoniales - La Constitución... (nota 2), p. 85.

56 Tal ocurre en la Conferencia de Bruselas, que se ocupó de las personas encargadas de su ejercicio, cuestión no falta de aspectos problemáticos - N. Pérez SerRano, El derecho moral... (nota 26), p. 24. El Acta de París de 1971, que actualiza el Convenio de Berna, se ocupa igualmente de este punto -A. MISERACHS RIGALT, Sistemas... (notas 5), p. 115-, asi como la Ley tipo de Túnez sobre el Derecho de Autor, en su artículo 5, -cir. Propiedad intelectual (nota 2), p. 1.395.

57 Cfr. P-30 (nota 8), p. 1.705b. P. Miserachs Sala, al formular su deseo de que el proyecto contuviera "una amplia y clara definición" de estos derechos, señalaba que "a fin de cuentas, son los que constituyen el orden protector más eficaz del autor y su obra" - La propiedad intelectual... (nota 52), p. 4.273. 
trucción más coherente y rigurosa, o bien apunte ante todo a la mayor operatividad práctica de las fórmulas en juego.

El nacimiento de las posturas «dualistas», que ponen especial énfasis en la existencia de dos tipos de derechos - personales y patrimoniales- del autor, encuentra sentido dentro del esfuerzo por abrir paso a los derechos "morales", superando la angostura del monismo que defendía una «propiedad» intelectual tomada en serio ${ }^{58}$. Una vez que el reconocimiento de esa dimensión personal se va consolidando, surge - por motivos de coherencia doctrinal- la tendencia contraria: superar un dualismo que disloca el tronco común de todos los derechos del autor. Este nuevo «monismo» post dualista considera fuera de duda la operatividad práctica de los derechos «morales» y a lo que aspira ahora - continuando, paradójicamente, la evolución cumplida por el dualismo- es a resaltar aún más su predominio, dado que son los más cercanos a la creatividad personal, fuente de todos los derechos del autor; mientras, a los derechos patrimoniales corresponderia una dimensión instrumental, disponible - por los vericuetos del proceso de explotación- incluso para los no autores.

Los planteamientos dualistas permitían fundamentar con más solidez unos derechos cuya falta de encaje dentro de la concepción patrimonial era patente: tenían un carácter personal e inalienable, que contrastaba con la transmisibilidad de los patrimoniales; buscaban la protección de un interés moral más que económico; su duración quedaba totalmente desligada de las peripecias surgidas por transmisión o caducidad de los patrimoniales. Otra ventaja operativa nada desdeñable era su más fácil tratamiento. En efecto, mientras el dualismo quedaba resuelto en el ámbito civil recurriendo a una ley especial -que recogía los derechos morales mientras el patrimonialismo del Código mantenía una aplicabilidad supletoria- en el ámbito penal cualquier intento de encaje monista, bien en el ámbito de protección de los bienes jurídicos personales bien en el de los patrimoniales, planteaba problemas o malentendidos ${ }^{59}$.

Cuando se olvida su doble tansfondo - histórico y de operatividad práctica - la polémica degenera en logomaquia embarullada. No es raro que se insinúe que «algunas de las doctrinas dualistas se prestan a una

58 El Dictamen de mayo del 85 de la Comisión del Senado (nota 8) refleja con nitidez esta situación, al recordar el carácter "estrictamente monista" de la ley de 1879 y señalar que «el reconocimiento de estos derechos personales del autor que más tarde se han llamado "derechos morales" ha dado origen a una doctrina dualista" -Propiedad intelectual (nota 2), p. 406a.

59 Ya en el citado Dictamen del Senado se había señalado: «los llamados derechos morales no son objeto de protección penal sino a costa de la aplicación de normas peregrinas y muy distantes de la voluntad de protección de la propiedad intelectual" — cfr. Propiedad intelectual (nota 2), p. 407a. La apelación a estos problemas en el debate no encontró sensibilidad alguna en la mayoría socialista, ni ante el Pleno - $P$-30 (nota 8), p. 1.707a- ni en Comisión -CG-DSC, III Legislatura, Comisiones, n. 131 de mayo de 1987 (en adelante C-131), p. $4.971 \mathrm{~b}$. 
construcción monista» ${ }^{60}$. Si se atiende a las consecuencias prácticas es más fácil calibrar de qué se está hablando realmente en cada caso. Con frecuencia, la autocalificación de un autor como monista o dualista no es sino una consecuencia refleja de la terminología que atribuye a la postura que aspira a superar. Un dualista, que aspira a superar la idea de los derechos de autor como propiedad especial (monismo inicial), no es sino un monista que se ha quedado a medio camino, si por monismo se entiende el afán de resaltar la unidad básica de todos los derechos que tienen como fuente la creatividad personal. Solo atendiendo a los resultados podremos calibrar en qué medida pueden estar próximos el paleomonismo patrimonialista y la propuesta de un «dualismo sintético o mitigado» ${ }^{61}$.

El proyecto enviado por el Gobierno a las Cortes no era un prodigio de rigor y coherencia, si observamos su tratamiento de estos aspectos. El título de la ley — «Propiedad intelectual»- evocaba una concepción paleomonista, a no ser que - al amparo de los fueros de la tradición- se entendiera tal «propiedad" de modo impropio, con las consecuencias ya apuntadas. Era propósito del proyecto evitarlas, de ahí que se presente como dualista, precisamente «porque reconoce no solamente derechos patrimoniales, sino también derechos personales o morales" ${ }^{62}$. Sin embargo, cuando el artículo 2 definia la «propiedad intelectual» nos la presentaba como «un derecho integrado por facultades de carácter personal y patrimonial», lo que nos situaría de nuevo en el monismo, quizá con intención renovadora ${ }^{63}$. Por si fuera poco, la Memoria que acompaña al proyecto - autorizada intérprete de sus elaboradores - afirma con no poca suficiencia que «el proyecto supera la concepción monista que tiene la ley de

$60 \mathrm{H}$. BAYLos opta decididamente por un monismo postdualista - Tratado... (nota 17), p. 603-, que le lleva a tomarse el término «propiedad intelectual" menos en serio que algunos de sus lectores. El diputado socialista DeL Pozo - C-128 (nota 9), p. $4.809 \mathrm{~b}$ - no oculta la confusión a que llevan las prolijas y bienintencionadas reflexiones de su fuente habitual (cfr. por ejemplo, las pp. 459 y 473 de la citada obra).

${ }_{61}$ Patentado por DEL POZO -C-128 (nota 9), p. 4.807b. Arquetipo de monismo patrimonialista E. Serrano Alonso -Sugerencias... (nota 25), pp. 60-61.

${ }_{62}$ El diputado socialista BALlesteros, al defenderlo ante el Pleno - $\boldsymbol{P}$-30 (nota 8), p. $1.710 \mathrm{~b}$. El senador del mismo partido BARRAL insistirá en ello, en momento posterior del debate $-S-46$ (nota 8), p. $1.757 \mathrm{~b}$.

a $D$. ESPIN CÁNOVAS, al resaltar el carácter dualista del proyecto de 1 de febrero de 1986, del que fue mentor -El proyecto de Ley de Propiedad Intelectual de 1986 "La Ley" 1986 (III), p. 975- alude al texto inicial del artículo 2: "un derecho integrado por facultades de carácter personal y patrimonial». No deja de resultar significativo que, cuando reitera esta afirmación en otro trabajo de similar fecha, lo haga líneas después de haber sentado que el dualismo implica la existencia de «dos derechos de naturaleza bien diferente, el personal o derecho moral y el patrimonial o derecho de explotación económica» - El derecho moral... (nota 42), p. 95ba. (subrayados nuestros) El Informe de la Ponencia del Congreso asumió la enmienda presentada, aunque - pese a sus buenos deseos- es dudoso que aceptara su "espíritu»; se conserva la alusión a la propiedad intelectual — «para mantener la tradición patria»- pero se la pasa a considerar «integrada por derechos de carácter personal y patrimonial» - (nota 29), pp. 143 y 157. De hecho la enmienda seria defendida en Comisión -C128 (nota 9), p. 4.812 b. 
1879, para decidirse por la vertiente dualista" ${ }^{64}$, con lo cual parece desconocer en qué medida hoy se ha llegado a un planteamiento monista que asume y transciende la aportación dualista, y, de camino, sitúa definitivamente en el paleomonismo al artículo antes citado.

De todo este barullo sólo un extremo queda claro. El proyecto opta por considerar a los «derechos del autor» como uno de los ingredientes de la "propiedad intelectual», y no viceversa. De ahí que los dos primeros libros se dediquen sucesivamente a los "Derechos de autor"(sic) y a "Otros derechos de propiedad intelectual». El intento de titular la ley como «de Derechos del Autor y Propiedad Intelectual», considerando a ésta como expresiva de unos derechos patrimoniales - accesibles a autores y no autores- subordinados, en todo caso, a los personales, no tuvo éxito ${ }^{65}$.

\section{Autoría y personalidad}

Cuestión doctrinal no debatida es si los derechos del autor deben o no considerarse derechos de la personalidad. Nos encontramos de nuevo ante una polémica que cobra a ratos apariencia bizantina, pero que resulta más inteligible si no se olvida que surge de la mano de la anterior. En efecto, la lucha contra el paleomonismo, que reducia a propiedad especial los derechos del autor, lleva a apelar a los «derechos de la personalidad" para acentuar al máximo su contenido «dualista» ${ }^{66}$. Cuando, más tarde, se de por superada aquella angostura, los "derechos de la personalidad" se verán marginados, no sólo por las dificultades de encaje planteadas por la doctrina, sino - sobre todo- para no mantener un dualismo que ahora es preciso superar ${ }^{67}$. En el interim se ha ido abriendo un interesante campo de problemas.

Los derechos de la personalidad parecian ofrecer los caracteres adecuados para facilitar el encaje de los llamados derechos "morales», poniendo así fin a su desconocimiento; o a su incómoda situación dentro de los contornos de la propiedad, por «especial» que se la considerara. Se trataría de unos derechos originarios o innatos, más «personalísimos" que

64 Memoria del proyecto... (nota 1), p. 5.

65 Cfr. C-128 (nota 9), pp. 4.806 y ss.

${ }^{66}$ Ilustrativas las referencias de N. PÉREz SerRano a la doctrina italiana -El derecho moral... (nota 26), p. 21.

${ }_{67}$ Las posturas de DE CASTRO y BERCOVITZ pueden servir como exponentes de ambos momentos -C. ROGELVIDE Bienes de la personalidad, derechos fundamentales y libertades públicas, Bolonia 1985, pp. 55-56. El voluntarioso intento clarificador de H. BAYLos fracasa por no marcar los tres momentos señalados; por ello, tras resaltar la conexión entre dualismo y derechos de la pesonalidad, acaba presentando la teoría de los derechos de la personalidad como monista por excelencia; pero se trata ya de un monismo postdualista... — cfr. Tratado... (nota 17), pp. 390 a 393,460 y ss. 
"personales», ya que esta calificación puede atribuirse a los derechos patrimoniales de crédito, para diferenciarlos de los reales. La extrapatrimonialidad, tan propia de los derechos morales, es por tanto una de sus notas esenciales, así como el ser «inherentes» a la persona, calificativo éste sobre el que habremos de volver. A fuer de extrapatrimoniales, serian indisponibles e intransmisibles. Tendrían, por último, también como los derechos morales, vinculación erga omnes ${ }^{68}$.

Con tales caracteristicas gozaban de una clara vecindad -en la frontera convencional entre lo privado y lo público - con las libertades públicas o con los derechos fundamentales. Al margen de los esfuerzos por mantener tan imprecisos límites ${ }^{69}$, esto los sitúa junto al punto de llegada de la evolución de los derechos del autor: su consideración como derecho humano ${ }^{70}$.

La doctrina parece decantarse por una negativa a la inclusión de los derechos del autor, o parte de ellos, entre los derechos de la personalidad. No tendrían carácter “esencial», ya que no todo hombre sería autor sino sólo aquellos que gozan de una peculiar creatividad; afirmación ésta notoriamente discutible provocadora de escarceos antropológicos que, probablemente, no son del caso. Se apunta también una sutil distinción entre la creatividad, «inherente» al ser humano, y los resultados objetivos y exteriorizados de ella. Estos, y no la "personalidad», real de los derechos del autor $^{71}$.

68 C. Rogel VIDE -Bienes de la personalidad... (nota 67), pp. 46 a 49 - siguiendo, sobre todo a BELTRÁN DE HEREDIA.

69 Las «libertades públicas», por falta de objeto suficientemente determinado, no serian propiamente "derechos". La consideración de los "derechos de la personalidad" como sinónimo iusprivatista de los derechos humanos tropieza con el anatema ideológico de los que quieren reducir el juego de los derechos humanos al enfrentamiento individuo-Estado, evitando que se conviertan en pieza decisiva de la justicia entre iguales - cfr. C. ROGEL VIDE, Bienes de la personalidad... (nota 67), pp. 42 y 53, y las notas de las pp. 89 y 122.

70 E. Serrano Alonso, utiliza como sinónimos "derechos de la personalidad o derecho fundamental» - Sugerencias... (nota 25), p. 59. Profundiza en ello J. J. LOPEZ JACOISTE, para el que a los derechos de la personalidad los derechos fundamentales «añaden concisión formal, invocabilidad difusiva $y$, sobre todo, cauces nuevos de ejercicio y defensan; a la vez, los derechos de la personalidad «indican lugares y áreas de donde los derechos fundamentales han de extraer la "razón práctica" que precisan para obtener implantación efectivamente ordenadora» - Una aproximación tópica a los derechos de la personalidad, "Anuario de Derecho Civil», 1986(IV), pp. 1.060 y 1.111; otras referencias de interés en pp. 1.079, 1.113 y 1.114. Cfr. también P. Miserachs SALA, La propiedad intelectual... (nota 52), p. 4.263.

$"$ Recalca la falta de "esencialidad" BELTRAN DE HEREDIA. La distinción creatividad-obra creada lleva a DIEZ PICAZO y GULLÓn a hablar de «facultades personalísimas" de un derecho del autor, que no sería «de la personalidad». Para otros, el derecho moral del autor sería más un «bien de la personalidad" que un derecho propiamente dicho - cfr. C. ROGEL VIDE, Bienes de la personalidad... (nota 67), pp. 56, 69 y 70,66; S. ORTIZ y X. O'CALLAGHAN, Sentencia deJ T.S. de 9 de diciembre 1985... (nota 27), p. 613. J. J. LóPEZ JACOISTE no entra a enumerar cuáles serian los derechos de la personalidad, precisamente por el carácter abierto de su perspectiva "tópica"; pero las referencias a su nacimiento o a su carácter irrenunciable, así como alusiones al derecho al nombre o a la sabiduría y destreza personal como expresión de la dignidad humana resultan claramente aplicables a los derechos del autor-Una aproximación... (nota 70$),$ pp. $1070,1.119,1.064$ y 1.068. 
El paralelismo con la polémica anterior es palmario. Se habría empezado reclamando la consideración de los derechos del autor como una especie de propiedad, precisamente porque tales derechos estaban tan ligados a la personalidad del sujeto como la propiedad misma, derecho humano por antonomasia. El paleomonismo de la ley de 1879 responde claramente a esta filosofía: "sin ese derecho, que asegura al hombre la propiedad de sus conquistas, limitaría el concepto de su personalidad»; «la obra intelectual, manifestación por excelencia de la personalidad humana, es por excelencia una propiedad" ${ }^{72}$. Al ir perdiendo la propiedad conexión estrecha con la «personalidad» se quedan a la intemperie los "derechos morales"; las posturas dualistas recurren al cobijo de los derechos de la «personalidad». Superada esa tesitura, los derechos del autor - con su dimensión patrimonial como instrumento subordinado- recobran su reconocimiento como derecho humano fundamental, decreciendo en consecuencia el interés de la teoria de los «derechos de la personalidad»; estos serian o un sinónimo iusprivatista o un cobijo de menor rango y amplitud. En todo caso, bajo las apariencias de la acerva polémica doctrinal, queda una realidad palmaria: tanto el paleomonismo como el dualismo o el monismo postdualista coinciden en considerar a los derechos del autor, o al menos a su dimensión «moral», como expresivos de la dignidad personal.

El proyecto no llega a reflejar explícitamente esta cuestión doctrinal, pero los autores de su Memoria no pierden oportunidad de poner a prueba su creatividad, con una afirmación tan drástica como sorprendente: "el derecho moral de autor (...) es un verdadero derecho de la personalidad (...). Asi lo reconoce la práctica totalidad de la doctrina e, incluso, la Jurisprudencia» ${ }^{73}$. De todos modos, si adoptamos un monismo postdualista que sitúa el centro de gravedad de los derechos del autor en su dimensión personal reconocemos a su núcleo central rango de derecho fundamental y propugnamos la relevancia de los derechos humanos en las relaciones entre particulares, la apelación a los «derechos de la personalidad» carecería ya de objeto.

\section{Viaje a la luna en el fondo de un almacén}

Cuando el famoso escultor Pablo Serrano recibió el encargo de realizar una escultura para instalarla en un hotel de Torremolinos quizá llegara a plantearse que su audaz concepción de un "Viaje a la luna en el fondo del mar» podría discrepar de los gustos artísticos de sus clientes; lo que

72 DanVILA ante las Cortes, al presentar la proposición de ley de 1879 — cfr. Propiedad intelectual (nota 2), pp. 334b y $340 \mathrm{~b}$.

${ }_{73}$ Memoria del proyecto... (nota 1), p. 5. El diputado socialista DEL POzo se niega a secundar tal audacia, prefiriendo una vez más a Barlos -C-128 (nota 9), p. 4.823b. 
difícilmente podria imaginarse es que dicha obra, más que cimentar como otras anteriores su bien ganado prestigio ante todo los que la contemplaran, la convertiría - oculta, desmontada-destruída, en un almacén- en el paladín de los derechos del autor en nuestro país. No es fácil tampoco que calculara que el proceso judicial que ponía en marcha ante el Juzgado $n$. 5 de Madrid fuera a prolongarse por variados vericuetos hasta encontrar, veinticinco años después, la respuesta definitiva a cargo de un entonces inexistente, e incluso difícilmente previsible, Tribunal Constitucional. Las dos etapas en que tal contencioso se desarrolla ${ }^{74}$ se convierten en un reconocimiento expresivo de las garantías prácticas de que gozan los derechos del autor en España durante dos períodos: uno, de casi cien años, entre la promulgación de la ley de 1879 y la de la Constitución de 1978, y otro, más breve, entre la refundamentación constitucional de nuestro ordenamiento jurídico en 1978 y la promulgación de la nueva ley en 1987.

El contenido de la sentencia de 21 de junio de 1965 ayuda a levantar acta del eco práctico que en dicho momento alcanzaban los debates doctrinales a que hemos aludido.

Destaca, ante todo, el fuerte predominio de la terminologia patrimonialista en el planteamiento de la cuestión. Influye, sin duda, el condicionamiento legal al que los interlocutores se ven sometidos. El litigio aparece como un contraste entre dos derechos de propiedad. En defensa del escultor se insiste en que, recibidos ya sus emolumentos, conserva sobre su obra "derechos de propiedad artística», por lo que cabe afirmar que "es propietario de la escultura», de la que «no dejaba de ser dueño» por el cobro de sus honorarios, ya que la escultura artísticamente "le pertenecía, con independencia del dominio adquirido" sobre ella por la empresa demandada. Como consecuencia, la "destrucción» de la obra al ser desmontada suponía una «agresión al derecho dominical» del autor sobre su obra $^{75}$.

Se ha convertido, para entonces, en lugar común el reconocimiento de un cierto "dualismo", de rigor doctrinal más o menos perfilado. Así, para el recurrente, "la propiedad intelectual se bifurca en dos grupos de poderes», mientras que la fundamentación de la sentencia prefiere admitir que "se ha perfilado en dos categorías de facultades" ${ }^{76}$. Ni uno ni otro llega, por tanto, a señalar la existencia de una duplicidad de derechos, como correspondería a un dualismo estricto.

${ }^{74}$ La primera de ellas, de la que ahora nos ocupamos, culmina en la sentencia de la Sala 1. del Tribunal Supremo de 21 de junio de 1965, que convierte en cosa juzgada los fallos previos de la Sala $3 .^{a}$ de la Audiencia Territorial de Madrid, de 6 de mayo de 1964, y del Juzgado $n .^{\circ} 5$ de la misma ciudad, de 9 de septiembre de 1963 (dieciseís meses después de ejecutada la obra).

${ }_{75} \mathrm{Cfr}$. Resultando primero, epigrafe primero; Resultando quinto, epígrafe segundo; Resultando primero, epigrafe quinto y Resultando primero, epigrafe segundo.

${ }^{76}$ Cfr. Resultando quinto, epigrafe tercero y Considerando primero. 
Nos hallamos dentro de los esfuerzos por superar el paleomonismo patrimonialista, bajo la presión de las exigencias de reconocimiento del "llamado - con mayor o menor propiedad-derecho moral del autor", por utilizar términos del demandante. La fundamentación de la sentencia es aún más expresiva, ya que, tras aludir a «un grupo de facultades que se concentran en lo que se llama usualmente derecho moral del autor", añade que se trata en esencia del «derecho personalisimo» del autor a: «decidir si su obra, y poder retirarla de la circulación». A tal derecho moral le atribuia el demandante los caracteres de “inalienable e intransmisible» ${ }^{77}$.

La clave de la fundamentación denegatoria radicará en la afirmación de que, no habiéndose desarrollado en España legalmente las previsiones del Convenio de Berna, se les reconoce solo el carácter de «conceptos meramente programáticos, que no pueden servir de fundamento a un Tribunal». La consecuencia es drástica: «al no estar desarrollado en nuestra legislación el derecho moral de autor, no puede declararse a favor de éste derechos que los preceptos legales no sancionan» ${ }^{78}$. La salida del paleomonismo no sería viable en la práctica, dada esta discutida postura sobre la validez interna de los tratados ${ }^{79}$; el resultado será el establecimiento de una postura patrimonialista extrema.

La sentencia parte de la distinción, que acabará resultándonos familiar, «entre la creación de la obra en sí y el ejemplar en que la misma se materializa y cobra corporeidad". Al autor corresponderia "la propiedad intelectual de su obra", de misterioso alcance, ya que "el comprador de la misma al adquirirla ostenta sobre ella un indiscutible derecho dominical», al que se van a aplicar sin remilgos los principios básicos de toda propiedad: tal derecho «sólo puede estar limitado por la voluntad de las partes o por la ley». La conclusión parece tan clara que se reafirma con un sorprendente estrambote: «la doctrina científica no se ha planteado la discusión de si, como derivado de la paternidad intelectual, el autor tiene derecho a impedir que el comprador suprima la obra artística si éste está en posesión real y plena de la obra adquirida, pues una de las facultades del dominio es la de poder abandonar o inutilizar la cosa» ${ }^{80}$. Más que una laguna, la falta de discusión parece certificar el carácter indiscutible de la capacidad de disponer sin límite de la obra de arte.

El autor, al vender su obra, ha transferido la propiedad sobre ella, que dándole sólo el derecho a considerarse su «propietario intelectual», aunque esto no le servirá ni para impedir su destrucción. El recién iniciado viaje a la luna en el fondo del mar queda convertido en chatarra en el fondo de un almacén. El responsable de tan penosa frustración no sería el juez,

${ }_{7}$ Cfr. idénticas referencias.

78 Cfr. Considerandos segundo y cuarto.

79 Al respecto N. PÉREZ DE CASTRO, El derecho de propiedad... (nota 24), p. 230.

Bo Cfr. Considerando segundo. 
que se atiene al ordenamiento vigente, sino la persistencia de una ley con ochenta y seis años a cuestas; su reemplazo cobrará urgencia, gracias a la tozudez de un renombrado escultor. Cuando, más de veinte años después, el Ministro Solana presente en rueda de prensa el proyecto llamado a sustituirla no renunciará a afirmar que, una vez convertido en ley, el caso Pablo Serrano no podría repetirse. Sin embargo, al intervenir en la siguiente Legislatura en el debate de totalidad del proyecto que le sucedió, el escultor no mereció ya los honores de la cita y, lo que es más grave, la omisión del Ministro podría incluso considerarse sintomática ${ }^{81}$.

\section{CREATIVIDAD HUMANA Y COMUNICACION}

La efectividad de unos compromisos internacionales, judicialmente reducidos a bienintencionada retórica, y la presión de litigios concretos, en los que nunca se pone en duda la justicia de las peticiones, sino que se recuerda - con aires de lamento - la falta de un apoyo legal que permitiera satisfacerlas, reclaman una ley que nunca llega. Lo que sí llega es algo más transcendental, que acabará afectando, mal que bien, a los derechos del autor: la elaboración de un texto constitucional, llamado a servir de cimiento y de humus al ordenamiento juridico de un flamante «Estado Social y Democrático de Derecho».

Ya vimos cómo la jurisprudencia constitucional comparada ofrecía ejemplos prácticos del avance que los derechos del autor iban encontrando en su protección, hasta recibir el tratamiento de derecho fundamentales. Tales textos constitucionales, y su desarrollo doctrinal y judicial, gravitan de manera indisimulada sobre el trabajo de nuestros constituyentes. Por si fuera poco, el tratamiento de los derechos humanos merece en la naciente Constitución una atención y detenimiento inusual. Influyen en ello el deseo político de marcar una clara distancia jurídico-politica con el régimen anterior, tras una transición tan felizmente carente de traumas sociológicos que podia acabar resultando poco perceptible. Buena parte de este rasgo debe atribuirse también a los afanes, políticos y académicos, de alguno de los padres ${ }^{82}$ del texto constitucional.

La Constitución portuguesa, que siguiera a la «revolución de los claveles», era el texto fundamental más cercano (en lugar y tiempo) con que contaban nuestros constituyentes. En su artículo 42, tras reconocer en el

81 Cfr. P-30 (nota 8), pp. 1.705 b y $1.710 a ; C-128$ (nota 9), p. 4.809a.

22 Se ha señalado con frecuencia la relevante labor de G. PECES BARBA, tanto a la hora de su justo reconocimiento como a la de las críticas, movidas en no pocas ocasiones por resabios académicos gremialistas. El mismo plasmó su experiencia en La Constitución española de 1978. Un estudio de derecho y política, Valencia 1981, en cuya p. 311 recoge su intervención relativa al artículo 20 . 
epigrafe 1 que «es libre la creación intelectual, artística y científica», se señalaba en el 2: «Esta libertad comprende el derecho a la invención, producción y divulgación de la obra científica, literaria o artistica, incluyendo la protección legal de los derechos de autor». El precedente ofrecido para dar paso a su reconocimiento como derecho fundamental de los españoles era inmejorable; sin embargo, el iter constitucional irá por vías menos explícitas.

\section{El debate constitucional}

En el anteproyecto de Constitución, el futuro artículo 20, antes de reconocer en su epígrafe 3 «la libertad de cátedra, de creación artística y de investigación científica», garantizaba en el epígrafe 2 «la protección de los derechos inherentes a la producción literaria, artística y cientifica». Es fácil observar la ausencia, para algunos premeditada ${ }^{83}$, de toda referencia explícita a los derechos del autor o a su tradicional versión española, la "propiedad intelectual»; pero la unanimidad es total a la hora de admitir que eran tales derechos los calificados de “inherentes" ${ }^{84}$. Las enmiendas presentadas en el Congreso ponen de relieve que tampoco entre los Diputados había duda al respecto.

Las propuestas de supresión coinciden en suscribir un planteamiento paleomonista, que considera a los derechos del autor como una propiedad especial, entendiénidolo en algún caso subsumido en el futuro artículo $33^{85}$. El informe de la Ponencia las rechaza explícitamente, introduciendo un cambio al que - dada la falta de justificación expresa- no parece dar más valor que el de una corrección de estilo: el epígrafe 2 se convierte en 1.b) y los derechos inherentes a la producción literaria se redactan como «derecho a la producción...» El posterior debate en Comisión

as Para E. Serrano Alonso al regular tal derecho «la insatisfacción terminología" dominante "es tenida en cuenta por el legislador constitucional», que «evita bautizarlo" con ella Sugerencias... (nota 25), p. 58.

${ }_{34}$ En la Demanda del recurso de amparo del caso Pablo Serrano se señala -(nota 7), p. 18a- que la alusión a tales derechos apuntaba «a la protección de los intereses morales y materiales de los autores" en línea con los textos de Naciones Unidas. El Informe de la Secretaria General relativo al carácter orgánico u ordinario del Proyecto de Ley de Propiedad Intelectual, realizado a petición de la Mesa del Congreso-Congreso de los Diputados, $n$. de Registro 8.116, p. 4, señala que «tales "derechos inherentes" son los constitutivos de la propiedad intelectual». Para F. J. GALVEz esta primitiva redacción "se limitaba al reconocimiento de la propiedad intelectual» - Análisis del articulo 20 en Comentarios a la Constitución, ed. por F. Garrido Falla y otros, Madrid 1985, p. 400.

8s Asi ocurre con la presentada por UCD, mientras que por AP el diputado CARRo MARTINEZ la considera "materia de ley ordinaria y no constitucional", y FERNANDEZ DE LA MORA apostilla en su justificación que, «si se reconoce el derecho de propiedad intelectual, habría que enumerar en la Constitución todos los derechos subjetivos de carácter civil" - Constitución Española. Trabajos Parlamentarios Madrid, Cortes Generales, 1980, t. I, pp. 123 y 163. 
demuestra que no se atribuye a esta modificación mayor alcance que el terminológico ${ }^{86}$, dando pie a un tratamiento pormenorizado de la cuestión en juego.

Mientras el ponente de AP glosaba brevemente las justificaciones ya aportadas por escrito por sus compañeros enmendantes, y el ponente de UCD eludia el trámite, ajeno sin duda a la elocuencia que se le acabaría atribuyendo a su gesto ${ }^{87}$, el socialista señalaba la existencia de «una tendencia científica a la desconstitucionalización» de la propiedad privada y «una tendencia paralela y contradictoria a la constitucionalización de esta producción y creación literaria, artística y científica" identificable con la propiedad intelectual ${ }^{88}$. Se establece, por tanto, con particular rotundidad el carácter fundamental de los derechos del autor ${ }^{89}$.

Pero el ponente socialista logró — sin duda bien a su pesar- algo más: poner las basespara que quedara demostrado definitivamente que la rotulación de los derechos del autor como propiedad no era en absoluto inocua. En vez de seguir el reciente ejemplo portugués y aludir-siquiera

36 El mismo Informe de la Secretaría General... -(nota 84), p. 5- que niega años después la inclusión de la "propiedad intelectual» en el citado artículo, reconoce que "en el sentir de los intervinientes, aquel precepto seguía, no obstante la alteración de su tenor literal, reconociendo tal derechos; extremo éste que será recordado en el debate de la nueva ley -C-128 (nota 9), p. 4.808 b.

${ }_{87}$ Preguntado el diputado Herrero Rodriguez de MiNon por el Presidente si consideraba "subsumida» en el Informe de la Ponencia la enmienda que ésta había rechazado, asintió -cfr. Constitución Española. Trabajos Parlamentarios (nota 85), p. 1.077a. Este gesto, previsiblemente marginal en un debate tan prolijo y prolongado, se convertirá en el Informe de la Secretaria General... - (nota 84), p. 7 - en fundamento decisivo para una conclusión sorprendente: «del estudio del proceso de elaboración del vigente artículo 20.1.b) resultan datos que permiten fundar opiniones contrapuestas acerca del problema considerado, sin que a su amparo pueda formularse un juicio definitivo sobre el mismo" (p. 22). Las afirmaciones de la doctrinal... (nota), p. 3c- "la voluntad del constituyente se desprende inequívocamente" de tal debate; tampoco tiene dudas F. J. GALVEZ "a la vista de los debates parlamentarios» - Comentarios... (nota 84), p. 400.

8. Constitución. Trabajos Parlamentarios (nota 85), t. I, p. 1.076a. En el debate de la ley se argumentará sin éxito que esta ufrase lapidaria" zanjó la cuestión al dar paso al rechazo de aquellas enmiendas por unanimidad $-C-128$ (nota 9), p. 4.806b.

${ }_{89}$ Lo reconocen incluso autores como E. SERRANO ALONSO que lo consideran desacertado - Sugerencias... (nota 25), p. 59. El único testimonio doctrinal al que se acierta a aludir en el Informe de la Secretaria General... - (nota 84), p. 19-es el trabajo de C. ALVAREz Romero - La Constitución... (nota 2), p. 78- en el que, tras no atreverse a suscribir tampoco el enlace con el artículo 33, se realiza esta notable afirmación; cla propiedad intelectual cabe perfectamente dentro de la Constitución y, por lo tanto, la institución debe vivir pacíficamente en su seno. Nos basta con esa certeza». De menor cuantía es la observación de J. M. CHICO ORTIz de que en la edición divulgativa previa al referendum constitucional el artículo 20 aparece acompañado por una nota previa al referendum constitucional el artículo 20 aparece acompañado por una nota marginal que alude a la elibertad de expresión» —Presente y futuro... (nota 30), p. 20-; aun admitiendo tan curioso indicio de interpretación auténtica, cabe señalar -observación por observación- que en el Indice analítico de la Constitución que acompaña la edición conjunta de su texto con el del Reglamento del Congreso, utilizada habitualmente por los diputados, el término "propiedad intelectual» remite al artículo 20.1 —Madrid, 1986(2. $\left.{ }^{\circledR}\right)$, p. 122a. 
en el debate- a los derechos del autor, se empeñó, probablemente en aras de añejas tradiciones, en basar todo su alegato en términos que podría haber suscrito Danvila un siglo antes: nos hallamos ante "una forma de propiedad mucho más espiritual, mucho más moral, que está mucho más vinculada directamente a la persona» ${ }^{90}$. La semilla polémica quedará sembrada y cuando, años después, se planteee si la regulación legal de los derechos del autor debe tener rango de ley orgánica, estas alusiones resultarán decisivas para dar una respuesta, que negará implícitamente su rango de derecho fundamental ${ }^{91}$.

Los comentadores de la Constitución coinciden en considerar «desafortunada» la redacción del precepto ${ }^{92}$. Sin duda, sus autores no eran conscientes de las últimas implicaciones prácticas del texto que aprobaban; ni en éste ni en otros muchos casos. El modo como se produce el debate del título relativo a los derechos fundamentales, consensuado en bloque y aprobado a marchas forzadas, multiplicaba este riesgo. Pero más que la «confusión de los parlamentarios ${ }^{93}$ es el debate doctrinal subyacente el que acabará imponiendo su propia dialéctica.

Aun maginando estos elocuentes antecedentes, un desapasionado examen del texto del artículo 20 debe bastar para encontrar en él incluídos con rango fundamental los derechos del autor, a no ser que se opte por una consideración del apígrafe 1.b) como reduplicación superflua de la libertad de pensamiento o de cátedra ${ }^{94}$.

Pero si fueran escasas las vicisitudes del articulo 20 -como posible encaje de un monismo postdualista en la consideración de los derechos del autor-y los atisbos de apelación al artículo 33 - para resucitar el planteamiento paleomonista de la propiedad intelectual como variante de

- Constitución. Trabajos parlamentarios (nota 85), t. I, p. 1.076.

9t Enlazando con la ya aludida "subsunción» de la enmienda de UCD, el «mantener esta expresión tradicional da pie para entender que su reconocimiento no se realiza en el artículo 20, sino en el 33, relativo al derecho de propiedad privada" - Informe de la Secretaria General... (nota 84), p. 12. Más allá de los juegos de palabras, el monismo postdualista, que animaba la postura triunfante en el debate constitucional, degenera así en el paleomonismo.

92 F. J. GÁLVEZ, considera que «no es suficientemente expresivo de su extensión real» -Comentarios... (nota 48), pp. 399 y 400 . También A. FernAndez Miranda y Campoamor -Análisis del artículo 20 en Comentarios a las leyes politicas, ed. por O. Alzaga, Madrid 1983, t. II, p. 501.

93 Apuntada por A. Fernandez Miranda - Comentarios... (nota 92), p. 500. Tampoco cabe considerar tan excesivamente "significativo" como hace el Informe de la Secretaria General... - (nota 84), p. 7 - que en posterior debate en el Senado no se aludiera para nada a la propiedad intelectual. Tal silencio, tras la aplastante votación del Congreso, más bien sería argumento favorable -C-128 (nota 9), p. 4.906 b. Por otra parte, el carácter consensuado del debate impide magnificar matices dejados a la retórica personal en una presunta discusión con resultado conocido de antemano. Sobre la frecuente falta de conexión en los debates de los grupos parlamentarios de Congreso y Senado de una misma formación política preferimos no abundar.

${ }^{24}$ Poco resquicio a la duda deja la rigurosa argumentación de A. FERNANDEZ-MiRANDA sobre el particular - Comentarios... (nota 92), pp. 545-547. 
la propiedad privada- los catálogos competenciales del artículo 149 acabaron contribuyendo también a esta imprevisible ceremonia de la confusión; su epígrafe 1. 9. ${ }^{a}$ considera competencia estatal exclusiva la «legislación sobre propiedad intelectual e industrial».

Aparece así, intempestivamente, uno de los términos que quizá se habían evitado cuidadosamente en títulos anteriores. Las posibilidades de formulación de hipótesis se multiplican. Para unos, la apelación a la upropiedad intelectual» no tendría mayor transcendencia que la de expresar una “inercia legislativa» ${ }^{95}$; para otros, excluiria toda consideración de los "derechos del autor» capaz de desbordar el marco de la propiedad ${ }^{96}$. En realidad este fleco, disponible para cualquier enganche, se limita a camuflar una nitida polémica: o los derechos del autor quedan confinados con la propiedad en el artículo 33, desprovisto de la protección específica de los derechos fundamentales; o, por el contrario, se integran — de la mano del monismo postdualista- en el artículo 20 con rango fundamental ${ }^{97}$. El artículo 149, al distribuir competencias, permite ambas soluciones: bien los derechos del autor, por su carácter fundamental exigen un tratamiento unitario en todas las Comunidades del Estado; bien la propiedad intelectual opera en un mercado unitario que las demarcaciones autonómicas no deben fraccionar. No excluye siquiera una tercera opción, rara vez planteada por el claro abandono del dualismo: los derechos morales encajarían en el artículo 20, mereciendo por tal razón ser competencia estatal exclusiva, mientras los de explotación (propiedad intelectual strictu sensu) por encajar en el artículo 33, exigen similar asignación.

\section{Distingos doctrinales y realidad jurídica}

Si el recurso a uno u otro rótulo no deja de acarrear consecuencias, más hondas aún pueden acabar siendo las repercusiones de los distingos

${ }_{95}$ Así C. Alvarez Romero, dentro de su dubitativo tratamiento del problema - La Constitución... (nota 2), p. 73.

96 Para J. M. Chico ORTiz, con el artículo 149 "queda marginado el anhelo europeo, y concretamente el francés de hablar de «derechos de autor» - Principios y problemas... (nota $3)$ p. 1.326. No parece muy acertado concluir — como se hace en el Informe de la Secretaria General... (nota 84), p. 11- que con ello la propiedad intelectual seria «la denominación que la Norma Fundamental da a los derechos del autor", ya que -como la misma ley reconocetambién los no autores gozan de tales derechos; una solución dualista no puede excluirse de modo tan expeditivo.

97 D. ESPIN CANOVAS, mentor del proyecto, da pie a esta atípica fundamentación constitucional - El proyecto de Ley... (nota 63), p. $972 \mathrm{~b}-$, pero se muestra llamativamente ajeno a la polémica jurisprudencial - cfr. infra notas (134), (135) y (194) - y, doctrinal entablada al respecto. Se limita a apuntar que la «libertad de creación intelectual» merece, como manifestación de la libre expresión de las ideas, "la protección especial del proceso preferente ante la jurisdicción ordinaria y del recurso de amparo ante el Tribunal Constitucional» - EI derecho moral... (nota 42), p. 99a. En el debate todos los diputados coinciden al admitir que el artículo 149 de la Constitución reenvia a otro anterior, aunque los portavoces socialistas no se pongan de acuerdo a la hora de precisar si se trata del 20 o del $33-C-128$ (nota 9), pp. 4.810 b y $4.811 \mathrm{a}$; $C-131$ (nota 59 ), p. $4.956 \mathrm{a}$. 
propios de la dogmática jurídica. La disección conceptual de los elementos de la viva realidad social facilita su encaje en modelos de decisión preparados para facilitar el trabajo del jurista práctico, cabrá así orientar en lo posible al sufrido ciudadano a la hora de consolidar sus expectativas. Pero este meritorio trabajo se convierte en arriesgada tarea cuando la distinción conceptual rivaliza con la realidad, amenazando con sustituirla. El debate subterráneo sobre si este proyecto debia o no ser tramitado con las exigencias de la legislación orgánica brinda ocasión de comprobarlo, a la vez que facilita una consideración más profunda del alcance de los derechos del autor.

Una primera distinción conceptual entra en juego: la que cabría establecer entre la libertad de creación de una obra artística inexistente y los derechos ejercitables en relación a la obra ya realizada. El deslinde no parece falto de fundamento real; ni de consecuencias jurídicas... En efecto, la libertad de creación podría quedar satisfecha con la protección propia de las «libertades públicas»: eliminación de injerencias estatales en la tarea individual; las referencias a terceros podrían no ser del caso. Por otra parte, los derechos sobre la obra creada, vinculados a un objeto exteriorizado ${ }^{98}$, pierden conexión directa con el autor y su dignidad, lo que convierte en dudoso su rango fundamental.

La distinción entre creación y obra creada abre un abanico de posibles consecuencias, que incluye la de servir de via a un regreso al paleomonismo. Reservada a la libre creación la protección reforzada del artículo 20, los derechos del autor sobre su obra ya creada habrían de conformarse con el débil cobijo que a la propiedad ${ }^{99}$ reserva el artículo 33 .

98 F. J. GaLvez fundamenta en ello la distinción entre "creación intelectual», derecho sobre bienes inmateriales «interiores» y los «derechos morales de autor o de propiedad intelectual», que «implican una exteriorizaión" de dichos bienes. Comentarios... (nota 84), p. 400-401; susribe esta postura J. G. STORCH -Derecho a la producción... (nota 23), p. 1.179a. También J. M. OTERO LASTRES detecta «dos bienes juridicos diferentes», aunque considera que la protección del primero de ellos - «el acto creador»- exige una «actuación positiva" del Estado, más allá de la mera no injerencia, por lo que considera también derecho fundamental al segundo - La protección constitucional... (nota 7), pp. 2b, 3b y c.

99 Esta es la postura suscrita por el Informe de la Secretaria General... que descartó el carácter orgánico del proyecto -(nota 84), pp. 11 y 12. Por el contrario, E. Serrano Alonso da por supuesto que la «propiedad intelectual» ha sido reconocida como derecho fundamental, por lo que no parece acertado que su género — «en este caso el derecho de propiedad»no goce de similar rango; termina apuntando que "seguramente hubiese sido más exacto no haber configurado como derecho fundamental ninguna de ambas situaciones" - Sugerencias... (nota 25), p. 59; J. M. Chico Ortiz suscribe el enlace con el artículo 33, en un primer momento, plantea una relación poco precisa con el artículo 20 , que parece abrir un posible dualismo "moral» - patrimonial -Presente y futuro... (nota 30), p. 19; sus referencias, años despues, a las vicisitudes de una posible expropiación de los derechos morales disipan toda duda -Principios y prob/emas... (nota 3), p. 1.334. 
El entusiasmo parcelador de la doctrina no se satisface, sin embargo, con esta primera división. La disección va haciéndose más detallada y los derechos se van multiplicando de modo incesante. Hasta cuatro aspectos llegan a individuarse: libertad de creación, obra creada, titularidad de ella y deslinde de facultades para su aprovechamiento ${ }^{100}$. Pero las posibilidades de gemacion no parecen conocer límite. El mismo Tribunal Constitucional ha contribuido a multiplicarla, al señalar que la libertad de creación no sería sino «una concrección» de la libertad de expresión o del derecho «a expresar y difundir libremente pensamientos, ideas y opiniones", lo cual ofrece nuevas posibilidades especulativas ${ }^{101}$. El problema, al final, consistiría en no perder de vista las consecuencias prácticas de tan apasionante juego, para no acabar dando paso a una caricatura, más o menos artística.

La actividad humana no es tan fácilmente parcelable en la realidad. Es la calificación jurídica, con su inevitable dimensión "constructiva» (no pocas veces destructiva) la que la diseca, con la mira siempre puesta en las consecuencias, más o menos "ajustadas", de la operación. Cabe, sin duda, distinguir fases en todo dinamismo humano; pero, ¿cuándo hay motivo para entender individuados derechos distintos? Habría que conceder que sólo cuando cada una de esas etapas teóricamente definidas conserva sentido en sí misma. Esto complica inevitablemente tan laborioso deslinde. ¿Nos hallamos ante derechos distintos o ante facultades de un mismo derecho? ¿Cabe trazar una clara frontera entre libre creación y derechos del autor? ${ }^{102}$

\section{Concepción, ejecución, comunicación}

Pensamos que aquella alusión de la jurisprudencia constitucional nos sitúa en la pista de un aspecto decisivo para dar respuesta a estas

${ }^{100}$ Para C. Alvarez Romero - La Constitución española... (nota 2), pp. 76-77- la Constitución sólo se preocuparía del primer aspecto y no entraría en los otros tres, que serían por cierto los concernientes a la «propiedad intelectual». J. G. STORCH se conforma con sólo tres derechos en su glosa a la sentencia de 1965: el derecho "a" ser autor tendria los atributos de los derechos de la personalidad, lo cual no ocurriría con el derecho "de" autor en su doble faceta -Derecho a la producción... (nota 23), p. 1.178b.

${ }_{301}$ Sentencia del Tribunal Constitucional 153 de 1985 de 7 de noviembre, fundamento 5 , con voto particular discrepante de Rubio Llorente «Boletín de Jurisprudencia Constitucional» («BJC») 1985 (54-55), pp. 1.372b y 1.373b. Para el Informe de la Secretaría General... - (nota 84), p. 13- esto probaría que los derechos del autor no tendrían encaje en el artículo 20 . J. G. STоRсн prefiere, por su cuenta, convertir en "facultades" los cuatro derechos contemplados en el citado artículo -Derecho a la producción... (nota 23), p. 1.178a.

102 P. MISERACHS SALA, tras admitir que el «derecho de crear» no es sino la primera de las «facultades» positivas en que se desglosa el derecho moral de autor, afirma que «el primer derecho del autor reconoce el artículo 20 de la Constitución es el de la "libertad de creación" - La propiedad intelectual... (nota 52), p. 4.267. Para el Informe de la Secretaria General..., por el contrario, la propiedad intelectual «solo puede considerarse como instrumento para alcanzar la constitucionamente exigida protección» de la libertad de creación intelectual -(nota 84), p. 18. 
cuestiones. Los derechos del autor, para poder considerarse incluídos en el artículo 20, habrían de reflejar los caracteres genéricos de toda la familia en él albergada; entre otros, el de contribuir al «mantenimiento de una comunicación pública libre» ${ }^{103}$. Pues bien, lejos de servir de argumento para rechazar tal inclusión ${ }^{104}$, esta nota puede dar un sesgo nuevo a los intentos delimitadores que venimos comentando.

La actividad artística no es un mero desahogo, que permita al inspirado autor dar rienda suelta a su creatividad. Si asi fuera, tendríamos en efecto sólo dos perspectivas: el autor antes de crear, con su derecho a que le dejen desahogarse en paz, y después de haber creado, con su derecho a vivir de ello si alguien está por la labor. Posible solución: derecho fundamental del creador a que le dejen en paz y derecho subjetivo ordinario a explotar su obra dentro de un orden (marcado por leyes ordinarias e incluso por normas de inferior rango).

La actividad artística es también comunicación de un sentido, con lo cual otro tercer elemento - la relación con su receptor-entra en juego ${ }^{105}$. Realizar una escultura no es poner fin a una acción, para dar con ello paso a unos derechos sobre su resultado; lo que ha hecho, en realidad el escultor es dar principio a un proceso de comunicación con los que la contemplen, en el que su creatividad se ve continuamente actualizada. Cuando el comprador de su obra la destruye, no se limita actuar sobre el «resultado» de su creatividad, sino que interrumpe el proceso de comunicación en que esa misma creatividad consiste, cercenándola en su raiz. No es tan fácil, pues,

103 Sentencia del Tribunal Constitucional 6/1981 de 16 de marzo, fundamento tercero —BJC", 1981(2), p. 132b.

${ }_{104}$ Como hace el Informe de la Secretaria General..., para considerar que el artículo 20 encierra una mera garantía constitucional de la libertad de creación, sin reconocer como fundamentales los derechos del autor - (nota 84), p. 10. Añade también como otro rasgo "familiar" del artículo el rechazo de toda censura, que considera inaplicable a los derechos del autor; pero la propia ley, en su artículo 43.4, considerará nulo el pacto para no crear en el futuro, cuyas consecuencias prácticas no son muy dispares - C-131 (nota 59), p. 4.953b. Al respecto D. ESPIN CANOVAS, EI derecho moral... (nota 42), p. 99a.

${ }_{105}$ F. J. Galvez resalta cómo cualquiera de las libertades del artículo 20 eimplica necesariamente un contacto más o menos intenso del individuo con sus semejantes", a diferencia de las libertades "que se refieren al individuo con abstracción de ulteriores relaciones" -Comentarios... (nota 84), p. 398. P. Miserachs SALA recoge una definición de la propiedad intelectual que la refiere a «las obras de la inteligencia que tienen por fin la comunicación de ideas" - La propiedad intelectual... (nota 52), p. 4.264. También en el debate se resalta cómo el autor no persigue sólo un rendimiento económico sino «la expresión y la comunicación de aspectos de especial riqueza de su propia personalidad" $-C-128$ (nota 9), p. 4.806a. D. ESPIN CANOVAS señala que las «diversas manifestaciones del derecho de explotación pueden resumirse en la comunicación directa o indirecta al público» -El proyecto de Ley... (nota 63), p. 976b. Quizá por ello, la nueva ley, tras aludir —en el contexto genérico del artículo 4- a la "divulgación" y "publicación" de la obra, vincula el concepto de "comunicación pública" a los «Derechos de explotación» (artículo 20), con una visión reductiva de su alcance. E. SERRANo ALONSO parte de la existencia de derechos de autor sobre obras carentes de calidad (¿también el de defender su integridad?) para rechazar esta dimenisión social —Sugerencias... (nota 25), pp. 77-78. 
aplicar a la comunicación artística la expeditiva distinción entre un hacer ( «in fieri») y algo hecho («in facto esse») ${ }^{106}$; porque la obra de arte, en la medida en que es fruto de una rica creatividad, se re-hace cada vez que es interpretada, por quien la contempla o por quien la ejecuta en comunicación con el autor, e incluso con el público ${ }^{107}$.

La creatividad, que permite al hombre - a diferenca de otros seres que le rodean - convertirse en uautor", consiste en la posibilidad de poner en juego un «augere», una capacidad de acrecentar lo real de una doble dimensión: en cuanto actualiza, exteriorizándolas, posibilidades implicitas de su hacer y en cuanto, con esto, abre una nueva posibilidad de relacionarse comunicativamente con los demás, suscitando en ellos elementos también hasta entonces implícitos. Esta realidad de la actividad creativa como relación comunicativa siempre abierta, y no como mero hacer que se cierra en un resultado objetivo, explica aspectos "morales" y patrimoniales de los derechos del autor.

El llamado derecho al inédito ${ }^{108}$, por ejemplo, que faculta al autor para negarse a publicar su obra, o a facilitar su difusión, demuestra su

106 A tal argumento acudió el diputado socialista DEL POzo para negar rango fundamental a los derechos del autor -C-128 (nota 9), p. 4.812a. Facilitaba este planteamiento en dos tiempos la definición de autor del artículo 2. del antiguo Reglamento, como aquel "que concibe y realiza" una obra ceintifica o literaria o "crea y ejecuta" alguna artistica -al respecto C. Rogel VIDE Autores, coatures y propiedad intelectual, Madrid 1984, pp. 51 ss. La nueva ley, en su articulo 5.1, considera autor al que «crea»; pensamos que ello incluye no sólo «concepción" y «ejecución" sino también una dimensión comunicativa. El senador socialista BarRal plantea como sinónimos «publicación" y «comunicación» de una obra, considerando que dan pie a "una especie de condominio natural entre la sociedad y el autor" $-S-46$ (nota 8), p. 1.768a. Su compañero, el granadino GARCIA LADRON DE GuEVARA, resalta también que todo bien cultural es "patrimonio social", rechazando gráficamente cualquier equiparación "de la Quinta Sinfonia de Mahler" con una fábrica de colchonetas", para concluir elocuentemente: "un autor, cuando escribe, compone, pinta, esculpe o modela, está dirigiéndose a la humanidad» -ibidem, pp. 1.771a y 1.773b. Desgraciadamente no derivaron de ello consecuencia jurídica alguna.

${ }_{107}$ El propio Tribunal Constitucional no deja de señalar cómo el cine o el teatro «constituyen un medio de comunicación entre los actores y los intérpretes y quienes asisten a ellos, y pueden servir de "soporte" o vehículo para la difusión social de un mensaje" - sentencia citada en (nota 101), p. 1.372a. Arquetipico resulta el caso planteado por el director cinematográfico Zefirelli al ver afectados sus derechos de autor por la fragmentación de su obra por cuñas publicitarias televisivas.

${ }_{108}$ Contemplado ya en el artículo $44,1 .^{\circ}$ de la ley de 1879 y recogido ahora en el 14 , 1. . Para N. Pérez SerRano tal derecho «pertenece al ámbito de la personalidad» - El derecho moral... (nota 26), p. 17; mientras J. M. CHICO OnTIz, más atento a las dimensiones patrimoniales, señala que "quizá el derecho de exclusiva se llevó a términos absolutos al conceder al autor $y$ herederos la facultad de manifestar en forma solemne su voluntad de que la bora no vea la luz pública" - Presente y futuro... (nota 30), p. 15. Su ejercicio por los herederos resulta condicionado por el artículo 40 de la ley, que recoge exigencias constitucionales derivadas del derecho a acceder a la cultura. 
señorio sobre una relación no consumada, quizá por no considerar aún maduro el momento comunicativo. Desde la distinción entre la libertad de crear y la disposición sobre la obra, sería más lógico imponer la publicación de todo lo libremente creado.

Lo mismo ocurre con el derecho de arrepentimiento ${ }^{109}$, que permite al autor - como dueño de su capacidad creativa- interrumpir una comunicación ya iniciada; claro que, precisamente porque la comunicación ya se había iniciado, entran en juego en este supuesto posibles derechos de terceros. Desde la distinción aludida, si se la suscribiera de modo drástico, resulta ininteligible esta posibilidad de anular un «resultado" ya producido, exteriorizado objetivamente y desvinculado, por tanto, de la dignidad subjetiva.

Incluso el derecho de continuidad («droit de suite»), cuyo carácter patrimonial y a la vez «irrenunciable e intransmisible» no deja de suscitar perplejidades ${ }^{110}$, sólo resulta inteligible desde esta nueva perspectiva. La frontera creación-resultado objetivo atribuiria con toda lógica al comprador la plusvalía que la obra de arte va cobrando en el mercado; pero, si ésta se entiende como fruto de un continuo proceso de comunicación entre autor y público, es fácil apreciar en qué medida obras posteriores han contribuído a enriquecerla, haciendo repercutir sobre ella nuevas dimensiones comunicativas que completan su sentido. Esto no dejará de traducirse también el juego de mercado ${ }^{111}$; pero, si nos quedáramos sólo en este último as-

${ }^{109}$ Es dudoso que la ley de 1879 lo recogiera, como piensa C. Alvarez Romero - La Constitución... (nota 2), p. 85- en su artículo 44, que más bien parece plantear un límite temporal al ejercicio del derecho al inédito. Ahora se lo recoge en el artículo $14,6 .^{\circ}$, en caso de "cambio de sus convicciones intelectuales o morales", lo que resalta su dimensión "moral» sin perjuicio de que se prevean posibles indemnizaciones a terceros. D. ESPIN CÁNOVAS, que lo considera una "grave excepción a la fuerza obligatoria de los contratos, cuando el autor hubiera cedido la explotación de la obra», ve su fundamento "en la primacia que el aspecto moral del derecho de autor alcanza sobre el aspecto patrimonial" -El proyecto de Ley... (nota 63), p. 975a. El mismo autor habla de una «recreación", para calificar el caso en que un autor siente «el imperioso deseo de modificar la obra ya creada y divulgada» — El derecho moral..., (nota 42), p. $97 \mathrm{~b}$.

${ }_{110}$ Irrenunciable e intransmisible considera el articulo 24.3 el derecho a exigir una participación en el precio de las obras revendidas en pública subasta. El texto legal es en, este caso, tan fiel al dualismo que se ve obligado a inventar una sección con el imaginativo título "Otros derechos", al no saber si tratarlo como derecho moral o de explotación; no faltaron en el debate caústicas alusiones sobre el particular - P-30 (nota 8), p. 1.710a y C-128 (nota 9), pp. 4.831 b $4.832 \mathrm{~b}$ - que no encontraron respuesta. La Memoria del proyecto... - (nota 1), p. 12- lo considera, sorprendentemente, “alejado del ámbito de los derechos morales". Para N. Pérez Serrano es un ejemplo arquetípico de la «propiedad retenida" de que goza el autor, al romperse el paleomonismo -Sugerencias... (nota 26), pp. 26-27.

11 El ministro Solana parece atento sólo a la dimensión económica, al aludir en el debate a una "revalorización" de las obras como consecuencia del «acierto (...) en su labor de autor» - $P-30$ (nota 8), p. 1.704a. En el proyecto de reforma de 1934 (artículo 46) el derecho suponía «un 25 por 100 de la "plusvalía"»; no faltaron ahora en el debate propuestas para elevar el 2 por 100 previsto $-P-30$ (nota 8), p. 1.718a- aunque las consecuencias en el juego del mercado serian imprevisibles. 
pecto, la intransmisibilidad o la irrenunciabilidad resultarian absolutamente caprichosas.

La dimensión «interpretativa» es común a toda obra de arte, en cuanto capaz de comunicar un sentido, y no el carácter específico de alguna de sus variantes, aunque en ellas resalte de modo más elocuente. Esta comunicación siempre abierta, - sin posible cesura entre la creación y el resultado- explica, por ejemplo, que el autor haya de ser tenido en cuenta a la hora de elegir los intérpretes de su obra o el director que la ejecutará; justificaría, incluso, que pudierá vetar su interpretación en determinadas circunstancias, que alterarían decisivamente el proceso comunicativo ${ }^{112}$.

El carácter «abierto» de esta comunicación que la creación artística pone en marcha no reviste sólo una dimensión temporal sino también personal. Lo que se abre es una comunicación «erga omnes», que no cabe encerrar en el marco de una relación bilateral. La dimensión «social» de la cultura, resaltada por el artículo 44, 1 de la Constitución, entra en juego. Quien adquiere una obra de arte no se convierte en «propietario» de la relación comunicativa que lleva consigo, ni puede por tanto, interrumpirla a su arbitrio por considerarla insatisfactoria o irrelevante, como ocurrió en los dos litigios aludidos en este trabajo ${ }^{113}$. Es un auditorio más universal, que tampoco puede identificarse simplistamente con el «mercado» ${ }^{114}$, quien mantiene esa comunicación y tiene derecho a no ser privado de ella. La acogida que este auditorio brinda, dificil sin duda de encerrar en términos cuantitativos, marca la vecindad entre los derechos del autor y el derecho fundamental al honor, como tendremos ocasión de señalar.

Enmarcada en este contexto real, la tarea de disección de la dogmática jurídica exige un tratamiento mucho más fluído. La consideración de la libre creación como una concrección de la libertad de pensamiento deja de ser argumento válido para excluir a los derechos del autor del

i12 La elección de intérpretes está contemplada en el artículo 80 de la nueva ley. Especialmente significativa la enmienda al artículo 38 defendida por el diputado de AP HUIDOBRo, por la que se admitiría la negativa del autor a que sus obras musicales puedan ser ejecutadas en el curso de actos oficiales o ceremonias religiosas; la argumentación socialista para rechazarla no pudo ser menos convincente - C-128 (nota 9), p. 4.849 y 4.850 .

${ }_{113}$ El caso de Pablo Serrano, al que nos venimos refiriendo, los compradores consideraron que la obra producía en el emplazamiento elegido un "efecto desastroso" -Demanda (nota 7), p. 2. En el caso Sistiaga, del que nos ocupamos más abajo. los titulares del local ignoraban el "valor pictórico que pudiera tener la obra incorporada i, ıno de los muros del edificio" y se declaran "sorprendidos (...) por el valor e importancia que el señor Sistiaga atribuía al indicado lienzo" - Sentencia del Juzgado n. 9 de Madrid de 30 de mayo de 1987 , de la que fue ponente el magistrado Jesús Ernesto Peces Morate, p. 3.

${ }_{114}$ En la sentencia de 30 de mayo de 1987 sobre el caso Sistiaga se señala acertadamente que las medidas tendentes a evitar la exhibición de una obra deformada o alterada son independientes del "valor en el mercado", que podrá ser relevante a efectos pecuniarios o indemnizatorios - fundamento octavo (nota 113), p. $14 \mathrm{~b}$. 
ámbito del artículo 20.1 de la Constitución ${ }^{115}$. Por el contrario, la comunicación - que a todos sus supuestos es común- integra en un mismo proceso de configuración, exteriorización y recepción ${ }^{116}$. La reflejan arquetípicamente los derechos del autor que -más que una «entre las medidas a adoptar para la eficaz instrumentación de la protección» de la libertad de creación- ven así constitucionalizado con ella su núcleo fúndamental ${ }^{117}$.

Cuando se desconoce este contexto resulta extremadamente coherente una conclusión: considerar equiparadas a todos los efectos la propiedad intelectual y la industrial, elevando a categoria la yuxtaposición competencial que propone el artículo 149 de la Constitución ${ }^{118}$. Si a la creación artística la privamos de su dimensión comunicativa, no tenemos ya una acción («augere») ${ }^{119}$, sino un mero fabricar («facere») que da paso a un resultado susceptible, más que de comunicación, de intercambio en el mercado. Desde esta perspectiva, lo único que realmente puede desentonar de la dimensión comunicativa del artículo 20 es la inoportuna vecindad, introducida tardiamente en el debate constitucional, entre creación «artística» y «técnica», en la medida en que este calificativo evoca operaciones meramente aplicativas.

La creatividad humana despliega, por tanto, una gama de virtualidades que se plasma en exigencias variadas, pero con un tronco común.

15 En contra de lo argumentado por el Informe de la Secretaría General... - (nota 84), p. 23. La afirmación de C. Alvarez Romero sobre el artículo 20.1.b) - «lo que en él se reconoce no es ninguna manifestación del derecho de propiedad", es acertada; pero sólo desde un planteamiento paleomonista de los derechos del autor cabe derivar de ello que lo que se reconoce y protege es solo un "prius lógico" o "presupuesto jurídico" - La Constitución... (nota 2), p. 74.

${ }_{116}$ Al respecto J. M. Otero LASTREs, que señala también que, si se pretende no sólo «reconocer» la libre creación sino también "protegerla», no puede dejarse al margen su "resultado" - La protección constitucional... (nota 7), pp. 2a y 3c.

11 Ambas posturas contrapuestas se ven suscritas respectivamente por el Informe de la Secretaria General... (nota 84), pp. 9 y $22-$ y por la elaborada Demanda -(nota 7), p. 32en amparo de Pablo Serrano.

${ }_{118}$ Asi lo hace el Informe de la Secretaria General... - (nota 84), pp. 16, 17 y 24 - que, tras considerar "sumamente reveladora» la comparación entre ambas, extiende a la primera la afirmación de que «no se identifica en modo alguno con la libertad de creación», aunque el Tribunal Constitucional sólo la ha emitido en relación a la propiedad industrial. Más matizadas las referencias de N. PÉREZ DE CASTRO, que le llevan a considerar constitucionalizada sólo la dimensión personal de los derechos del autor - El derecho de propiedad... (nota 24), p. 225. Críticas a la equiparación entre propiedad intelectual e industrial no faltan en el debate - C-131 (nota 59), p. 4.953b. El senador de AP DELOS MOZOS Y DE LOS MOzOS no pierde ocasión de insistir en las diferencias entre ambos derechos $-S-46$ (nota 8), pp. 1.765b y $1.775 \mathrm{a}$ admitiendo entre ellos sólo una analogia procesal-CG-DSS, III Legislatura, n. ${ }^{\circ} 47$ de 8 de octubre de 1987 (en adelante S-47), p. 1.787b.

${ }_{119}$ «Elementos personales que están presentes en todo trabajo, pero muy especialmente en el trabajo artístico y cultural» $-P-30$ (nota 8 ), p. $1.705 \mathrm{~b}$. Al respecto El trabajo como fuente de socialización con el que hemos contribuido a los Estudios sobre la "Laborem exercens", Madrid 1987, pp. 317-344. Nos parece poco afortunada la alusión de H. BAyLos a un "facere» como característica del «derecho de los creadores" - Tratado... (nota 17), pp. 601602; no en vano el título de su obra alude a la propiedad industrial e intelectual, por ese orden. 
El fundamento teórico de un monismo postdualista en la consideración de los derechos del autor es el mismo que justifica el entronque entre estos derechos y la libertad de creación. Esta no debe considerarse como su mero presupuesto o "prius lógico" sino como su auténtico motor; como una libertad positiva, real y efectiva y no un simple freno negativo a las posibles injerencias estatales. La alusión expresa a los derechos del autor en la Constitución - siguiendo el modelo portugués- habría clarificado decisivamente el contenido que sus mismos elaboradores suscribieron por unanimidad, tras un debate tan impreciso terminológicamente como doctrinalmente concluyente.

De la libertad de creación al último derecho patrimonial del autor asistimos al despliegue de una misma actividad humana ${ }^{120}$. ¿Cuáles deben ser los segmentos de su calificación jurídica? Después de lo expuesto, no dudamos que el rango de derecho fundamental corresponde no sólo a una defensiva libertad de creación sino a esa creativa apertura a la comunicación, que incluye obligadamente el núcleo básico de los derechos del autor.

Sólo quedaría para dictaminar si tal núcleo afectaría estrictamente a los derechos «morales» o también a los patrimoniales. No sólo la referencia a los cocumentos internacionales ${ }^{121}$, sino la mera superación de un dualismo simplista, invita a pensar que, aun gozando los derechos morales de un lógico protagonismo, la garantía reforzada propia de los derechos fundamentales debe respaldar también la dimensión patrimonial en la medida que contribuya a considerarlos real y efectivamente satisfechos. Incluir sólo los derechos morales en el artículo 20, para remitir los patrimoniales el artículo 33, sería quedarse en ese dualismo excesivo al que el proyecto decia apuntar, aunque distara de alcanzarlo. Tampoco sería posible, sin retroceder al paleomonismo, reconocer rango fundamental a cualquier di-

120 Esta continuidad se resalta en el debate $-P-30$ (nota 8), p. 1.706a. Ya en el Decreto 2.220 de 1975 de 24 de julio, que modifica los estatutos de la SGAE, se consideraba integrada en esta sociedad «a toda persona creadora de derechos de autor" - Propiedad intelectual (nota 2), p. 283a-, marcando este claro enlace con más acierto que la nueva ley. El Informe de la Secretaría General... - (nota 84), p. 9- aun admitiendo que la libertad de creación sin la «propiedad intelectual» podria ser "un simple nominalismo», rechaza que este argumento pueda respaldar su inclusión en el articulo 20; para evitar «un evidente vicio de orden lógico", habria que considerar reconocido "lo que resulta del tenor del precepto" constitucional mientras que el resto del ordenamiento podrá contribuir a su eficacia pero no a definir su contenido. Todo ello es perfectamente suscribible. La desviación decisiva se produce cuando - gracias a una forzada interpretación de los antecedentes de su debate- se decide ignorar que el "tenor del precepto" no sólo contemplaba los derechos del autor sino incluso lo defectuoso de su planteamiento terminologico como "propiedad".

121 La alusión de los textos de Naciones Unidas a los «intereses morales y materiales" preside la polémica doctrinal. Hay quien parece apoyar en aquella el rango fundamental de todos los derechos del autor -así J. M. Otero Lastres, La protección constitucional... (nota 7), p. 4 bc. El mismo Informe de la Secretaria General... sólo evita tal consecuencia negando a los derechos del autor encaje en el artículo 20 , con lo que tales textos no entrarian en juego por la vía del artículo 10.2 -(nota 84), p. 12. 
mensión de una «propiedad intelectual» ${ }^{122}$, disponible incluso para los no autores.

Más que el carácter "moral» o patrimonial, lo que permitirá considerar a un derecho del autor como ingrediente de ese núcleo fundamental constitucionalizado en el artículo 20 será su mayor o menor vinculación con la dimensión de dignidad personal que la creatividad lleva consigo. Esto exige una continua tarea interpretativa -primariamente legal, complementaria y subsidiariamente judicial- que vaya delimitando ese núcleo. En la medida en que nuestra flamante ley no ha estado a la altura de las circunstancias, la tarea judicial no podrá limitarse al complemento vitalizador que le es propio, sino que habrá de afrontar sus responsabilidades subsidiarias, ejerciendo -mal que le pese- mayor protagonismo. Pero del diálogo, tácito o expreso, entre jueces y legisladores a lo largo de la gestación del proyecto hablaremos en posterior apartado.

\section{Los derechos del autor en el fondo del mar}

La tenacidad del escultor Pablo Serrano hizo posible que dispongamos también de un expresivo caso práctico sobre las consecuencias del debate doctrinal al que acabamos de aludir. Si la sentencia del Tribunal Supremo de 21 de junio de 1965 levantaba acta del escaso grado de reconocimiento que los derechos del autor encontraban efectivamente entonces en nuestro ordenamiento, veinte años después -el 9 de diciembre de $1985-{ }^{123}$ el mismo Tribunal se veía abocado a hacer balance de esta prolongada polémica.

La falta de apoyo legal habia justificado en la primera ocasión la negativa a respaldar unas peticiones sobre cuya justicia se prefería no entrar en discusión. La promulgación de la Constitución de 1978, con cuyo artículo 20, 1 b) parecía haber emparentado la «propiedad intelectual», permitía colmar tan lamentable laguna ${ }^{124}$. Aunque la viabilidad del cauce procesal elegido acaba protagonizando el litigio, se hizo imprescindible afrontar como cuestión previa el rango que, tras la Constitución, había que reconocer a los derechos del autor. La existencia, junto al parecer de la

122 Resulta razonable la resistencia de N. PÉREZ DE CASTRO a «privilegiar, elevándolo a categoría de derecho fundamental, el derecho de propiedad sobre un cuadro". Una vez más la terminología («propiedad intelectual" en vez de «derechos del autor») se muestra perturbadora. D. ESPIN CANOVAS ya había señalado que «el derecho de propiedad del adquirente no confiere ningún derecho de los atribuídos a la propiedad intelectual» —El proyecto de Ley... (nota 63), p. 975b. La conclusión de la autora citada, limitando el rango de derecho fundamental a las "facultades personales" - El derecho de propiedad... (nota 24), pp. 223 y 224- nos parece restrictiva en exceso.

${ }_{123}$ El texto de la sentencia, que se había visto precedida por otras del Juzgado de primera instancia $n .^{\circ} 3$ de Madrid, de 22 de mayo de 1984, y de la Sala $3 .^{a}$ de lo Civil de la Audiencia Territorial de Madrid, de 16 de enero de 1985, cabe encontrarlo acompañado de los comentarios citados en (nota 27).

${ }^{124}$ El Considerando (1) de la sentencia alude al final, a «la vieja ley de 10 de enero 
mayoria, de un voto particular convierte en debate lo que podía haber tenido aires de dictamen conclusivo.

La sentencia suscribe la tajante separación entre la libertad de creación y los derechos del autor. Lo que la Constitución "consagra como fundamental es un derecho genérico e impersonal, a producir o crear obras artísticas, pues no toda persona crea o produce arte». Sólo cuando esto ocurre se produce un "resultado, que hace surgir un derecho especial, el derecho de autor». En la medida en que la actividad creativa lleva consigo una "exteriorización», da paso al "nacimiento de otro derecho" -en favor del público o de un eventual adquiriente- que no tiene ya por objeto aquel «bien inmaterial» sino uno «material». Tendríamos, por tanto, una libertad genérica, con rango de derecho fundamental, y dos derechos - del autor y del propietario de su obra - que pueden plantear problemas de «coordinación», teniendo en cuenta los «intereses que entran en juego» ${ }^{125}$.

Para el voto particular, por el contrario, cuando se actúa sobre una obra de arte, mediante «la alteración o disgregación de sus elementos, almacenándolos", se "afecta indudablemente a la producción y creación artística, cuyo reconocimiento y protección proclama el epígrafe b) del apartado 1 del artículo 20" ${ }^{126}$. La disonancia no termina aquí, ya que el Magistrado discrepante no duda en tomar postura sobre algunos de los aspectos de los derechos del autor más debatidos por la doctrina.

Su punto de arranque será la opción resuelta por un planteamiento dualista. La dimensión personal y patrimonial se consideran «emanantes del doble derecho que indudablemente integra el que tiene el autor" ${ }^{127}$. Se ha superado el paleomonismo, presente explícitamente en la sentencia de 1965 e hibernado en la actual; la polémica se plantea aún de modo demasiado frontal como para dar paso a un monismo superador. De ahí la reiterada presentación del derecho «moral» del escultor como «propiedad» o "dominio residual», "parificado con el derecho de dominio de la obra» ${ }^{128}$ correspondiente al comprador.

La opción por el dualismo se ve acompañada, como es habitual, por la presentación del derecho "moral» como "derecho de la personalidad", enumerando pormenorizadamente sus caracteres: «absoluto, no evaluable

de 1879 , que no permitía una solución diferente», mientras el siguiente comienza señalando que «el nuevo planteamiento se basa en el cambio de legislación producido en España a partir de la promulgación de la Constitución política de 1978 y de las leyes que, en este punto, la complementan».

${ }_{125}$ Considerando (3).

${ }^{128}$ Fundamento de derecho segundo del voto particular formulado por el magistrado A. Fernandez Rodriguez.

${ }_{127}$ Fundamento de derecho tercero del voto particular.

128 Ibidem. El derecho moral debe estimarse «comprendido entre los derechos fundamentales", "por proyección de propiedad residual " —ibidem fundamento de derecho segundo. El «ejercicio de la actividad derivada de la propiedad residual» del autor ha de llevarse a cabo "con pleno respeto al derecho de propiedad, derivado de adquisición" —ibídem fundamento de derecho cuarto. 
en dinero, inalienable, intransmisible e imprescriptible" ${ }^{129}$. Falta, precisamente, la nota que llevará al ponente de la sentencia, reiterando sus propias posiciones doctrinales, a negarle tal condición: «no es un derecho de la personalidad porque carece de la nota indispensable de la esencialidad", ya que no toda persona es autor ${ }^{130}$. No deja de ser significativa, a la vez, la coincidencia en ambas posturas al identificar el reconocimiento o negación del carácter de derecho de la personalidad y del rango de derecho fundamental.

El planteamiento de unos derechos fundamentales como libertades "genéricas", ajenas a sus «resultados", supone - más allá de la consideración de los derechos del autor- una determinada visión de la relevancia del texto constitucional. Ello se pondrá de relieve en el debate procesal que, en paralelo al substancial, acaba protagonizando la sentencia. El tesón de Pablo Serrano - para conseguir que su «Viaje a la luna», res- . catado del almacén, encontrara la libertad "en el fondo del mar»- encuentra apoyo en un doble dato: la aplicabilidad directa de una Constitución refundamentadora de todo el ordenamiento juridico y las vías de protección reforzada que su artículo 53, 2 prevé para los derechos fundamentales.

Más allá del prolijo debate sobre los cauces procesales que la legislación ofrece, el núcleo de discrepancia se centra en el grado de vinculación de los preceptos constitucionales, y muy especialmente del artículo 20. La "eficacia directa y aplicativa inmediata» de la Constitución permitiría esquivar el veto de cosa juzgada, al haber surgido una ilegitimidad sobrevenida. Por el contrario, la sentencia - sin llegar a «privar de toda eficacia directa" al artículo 20, "para reducirlo a una norma de programa cuyo único destinatario es el legislador, un mero principio" ${ }^{131}$ interpreta que la función de limite que su apartado cuarto atribuye a «los preceptos de las leyes que lo desarrollen" supone la remisión premeditada a una «interpositio legislatoris». La consecuencia para el posible rango fundamental de los derechos del autor es decisiva: a su juicio, «la fórmula genérica del artículo veinte, uno b) del texto constitucional no fue producto de la imprecisión, sino introducción conscientemente»; tanto el rango de los derechos del autor como «sobre todo» su cauce de protección jurisdiccional, "ha quedado intocado, pendiente de su estructuración legislativa» ${ }^{132}$. Mientras que el voto particular apunta que «condicionar la "protección" de un derecho subjetivo es condicionar indebidamente el "agere

129 Fundamento de derecho tercero del voto particular. Ya, al recoger las pretensiones del demandante, alude la sentencia al "derecho moral de autor, de carácter personalísimo» - Considerando (1).

${ }_{130}$ Considerando (3). Fue ponente el magistrado J. Beltrán de Heredia y Castano, a cuyos planteamientos doctrinales ya se aludio- en (nota 71).

${ }_{13 t}$ Como señala la posterior Demanda ante el Tribunal Constitucional -(nota 7), p. 24-, queriendo quizá explicitar su transfondo. Las referencias a la "eficacia directa" se encuentran en el Considerando (2) de la sentencia que comentamos.

${ }_{132}$ Considerandos (3) y (8). 
licere" del propio derecho", la sentencia suscribe una drástica inhibición -en aparente obsequio del propio texto constitucional- renunciando a lo que considera una creación de nuevos cauces procesales por vía jurisprudencial ${ }^{133}$.

La interpretación del artículo 20 como mera plataforma programática, a la espera de una delimitación legal precisa, complica la posibilidad de acceso a la via privilegiada del artículo 53,2 , en la que el demandante busca cobijo. Interpretaciones no menos restrictivas llevarán en la sentencia a la conclusión de que los derechos contemplados en el artículo 20, 1 b) no tendrían disponible dicho procedimiento preferente y sumario. En efecto, la ley 62/1978 de Protección Jurisdiccional de los Derechos Fundamentales - pre constitucional por unos dias- no lo contemplaba de modo expreso por lo que estaría justificado el rechazo de la demanda por inadecuación del procedimiento ${ }^{134}$. La falta de alusión expresa -en su artículo 1,2- a la libre creación artística enlaza con su ausencia en la relación ampliadora que ofrece el Decreto legislativo $342 / 1979$ de 20 de febrero. Por último, la Disposición transitoria segunda, dos de la Ley Orgánica del Tribunal Constitucional de 3 de octubre de 1979, que señala que el ámbito de protección jurisdiccional de los derechos fundamentales «se entiende extendido a todos los derechos y libertades a que se refiere el expresado artículo 53,2 de la Constitución", sólo se considera aplicable a la vía contencioso-administrativa, pero no a la penal ni a la civil aquí planteada ${ }^{135}$. Ya es mala suerte...

Estos obstáculos procesales llevarán —al filo de una siempre resbaladiza distinción entre fondo y forma- a lo que será una constante en tan ilustrativo litigio: la renuncia de los jueces a afrontar una pretensión de fondo ${ }^{136}$, sobre cuya justicia no se insinúa el menor reparo. Esto permite que no lleguen a abordar un último posible obstáculo procesal: el cómputo adecuado del plazo para la interposición de un recurso, que no se considera viable. El voto particular deja incoada la solución, al considerar que el agra-

133 Fundamento de derecho segundo. Al respecto el comentario de S. Ortiz NavaceRRADA - (nota 27), p. 611- que contrapone esta actitud "al sentido más progresivo del voto particular".

i34 Así lo hicieron las tres sentencias que agotan esta segunda fase del interminable litigio; la última en su Considerando (4). Esto produce una curiosa situación que invita al "estupor»: "que se haya permitido que la reclamación de protección de un derecho fundamental discurra por los cauces de un procedimiento que a la postre resulta ser inadecuado", en vez de remitir a la parte al pertinente; por si fuera poco, se emplean «dos años largos de tramitación procesal" para un procedimiento sumario y preferente - $\mathrm{S}$. ORTIZ NAVACERRADA (nota 27), p. 611.

${ }_{135}$ Considerandos (4) y (6). El voto particular centra su discrepancia en un rechazo de la interpretación restrictiva de la Ley orgánica del Tribunal Constitucional, cuya disposición transitoria 2.", 2 considera "como explícito reconocimiento de la vinculación inmediata de lo que emana de la propia Constitución, determinante de que no necesita una "interpositio legislatoris", es decir, una intervención del legislador ordinario para que sus normas puedan y deban ser aplicadas" - fundamento de derecho segundo.

${ }_{138}$ Considerando (8). 
vio a los derechos del autor "persiste», ya que los «efectos" de la situación son «duraderos» ${ }^{137}$.

Si se admite, de acuerdo con el Magistrado discrepante, el rango fundamental de los derechos del autor, quedaría por precisar aún si alcanzarán sólo a su vertiente "moral» -contemplada expresamente en algunos pasajes de su fundamentación ${ }^{138}$ - o también a la patrimonial —como se acaba indicando en otros ${ }^{139}$ - y con qué límites.

Entre tanto el número de derechos fundamentales implicados en el juego práctico de los derechos del autor ha aumentado. Al abordarse las vicisitudes de su protección jurisdiccional es el artículo 24.1, con su rechazo de la indefensión, el que resulta aludido ${ }^{140}$; pero, al hilo de una argumentación que se esfuerza por buscar cauce procesal a unas justas pretensiones, saldrá también a relucir el parentesco con el derecho al honor. Mientras que el demandante - procurando evitar la angostura de la vía procesal- plantea la ínfracción del artículo 18.1 alternativamente a la del 20.1 b), en lo relativo «al honor y reputación artísticas», y el Magistrado discrepante - haciéndole eco de tal planteamiento-considera afectado el derecho «moral» por cualquier «modificación que fuere perjudicial al honor o reputación del autor ${ }^{141}$, la sentencia - como un argumento más para negar fundamento a la protección reforzada de los derechos del autorresalta cómo la ley de 5 de mayo de 1982 de proteción al honor, a la intimidad personal y familiar y a la propia imagen - «estrictos derechos de la personalidad" todos ellos- no los contempla, porque "el legislador, con toda justeza y acierto jurídico, no equiparó» unos y otros ${ }^{142}$.

Los cien años transcurridos pesan sobre la ley anterior en un triple aspecto. El primero - más acuciante a corto plazo, y también más super-

${ }_{137}$ Fundamento de derecho cuarto, haciéndose eco del Considerando (2), cuando afirma que «subsiste el efecto del acto». Este punto resultaria especialmente debatido al plantearse posteriormente recurso de amparo ante el Tribunal Constitucional.

${ }_{138}$ Fundamentos de derecho segundo y tercero; apelando en este último al enlace con el derecho de libre expresión, para obviar quizá — con esta alusión implícita a la ya comentada doctrina del Tribunal Constitucional - la inadecuación de procedimiento suscrita por la mayoría.

${ }^{139}$ El demandante incluia, desde la primera instancia, entre sus pretensiones el reconocimiento como derecho fundamental de «los derechos moral y patrimonial de autor" -Resultando (1). El voto particular, tras considerar cconstitucionalizado el núcleo esencial del derecho del autor a sus intereses morales y materiales» -fundamento de derecho tercero-, en alusión expresa al artículo 27.2 de la Declaración de Derechos Humanos de Naciones Unidas, insiste en que dentro del artículo 20.1.b) de la Constitución "hay que entender quedan comprendidos los derechos moral y patrimonial del autor» - fundamento de derecho cuarto y fallo.

${ }_{140}$ Fundamento segundo del voto particular, respondiendo al primer motivo de casación recogido en el Resultando (5).

141 Segundo motivo de casación, recogido en Resultando (5). El voto particular equipara "perjuicio moral" con "menosprecio», al analizar las consecuencias del desguace de la controvertida escultura -fundamento de derecho tercero.

142 Considerando (5). 
ficial-se traduce en la presión de los colectivos más variados, que aspiran a encontrar posibilidades de acción que la vieja ley -pese a sus cautas invocaciones genéricas - no habia podido contemplar con la deseable concreción. Pero reducir a esta dimensión el problema, y pretender resolverlo mediante pactos y cabildeos con los directamente implicados, sería una actitud notablemente miope.

Largos años de polémica doctrinal situaban a los legisladores ante la indeclinable responsabilidad de diseñar un modelo coherente de los derechos del autor, aprovechando el terreno trillado por los especialistas. Por si fuera poco, el caso Pablo Serrano había ayudado a poner a prueba las deficiencias de las vías de efectividad jurisdiccional. La demanda planteada asumia deliberadamente un papel arquetípico y «ejemplar», al anunciar que la indemnización solicitada seria destinada en becas y ayudas para la protección jurídica de los artistas ${ }^{143}$. El propio Ministro, al presentar el proyecto, se hacía eco del problema: «son muchas las razones que obligaban al Gobierno a traer esta ley, pero sin duda la más importante era la ausencia de una protección efectiva a aquellas obras de ingenio" ${ }^{144}$. Quedaba, pues, un nuevo reto planteado.

En tercer lugar, los jueces —obligados a cubrir los huecos de una legislación desfasada- no perdían ocasión de recordar al Legislativo su responsabilidad en la situación. No se habian mostrado muy sensibles a los planteamientos ya dominantes en el derecho comparado, apelando - para justificar su actitud-al imprescindible respeto a los límites de su función. La sentencia de 21 de junio de 1965 consideraba los acuerdos de la Unión de Berna como «conceptos meramente programáticos, que no pueden servir de fundamento a un Tribunal para hacer declaraciones de derecho», dado que "en España no se ha adaptado aún la legislación" ${ }^{145}$ a tales exigencias. La sentencia de 9 de diciembre de 1985, tras señalar la falta de una adecuada "estructuración legislativa" de los derechos del autor, recuerda que "no es misión que corresponda al juzgador, limitado por ley a la interpretación del derecho» ${ }^{146}$. Por otra parte, su interpretación del artículo 20 -como marco premeditadamente hueco, a la espera de desarrollo legislativo- invita al juez a inhibirse excepcionalmente, abandonando su deber ordinario de desarrollar unos preceptos constitucionales de aplicación directa. Faltaba por ver si el Legislativo iba a estar a la altura de tan exigentes circunstancias. Mientras, la tercera fsase del ya legendario litigio estaba a punto de cerrarse con una sentencia del Tribunal Consti-

${ }^{143}$ Así lo recoge el Resultando (1) de la sentencia y el fundamento de derecho quinto del voto particular. En la subsiguiente Demanda - (nota 7), p. 37b-de amparo ante el Tribunal Constitucional se insiste en "el carácter "ejemplar" (en el sentido de los dommages -interêts exemplaires de la jurisprudencia francesa) que tiene la indemnizabilidad de las lesiones de derechos fundarnentales".

${ }_{144} P-30$ (nota 8), p. $1.702 a$.

145 Considerando (2).

146 Considerando (8), aludido en el debate parlamentario $-P$-30 (nota 8), p. 1.706 b. 
tucional. La actitud de los legisladores al respecto parece más de expectante escucha que de decidida asunción de las responsabilidades en juego.

\section{ENTRE EL PODER LEGISLATIVO Y EL JUDICIAL}

Contamos con indicios para poder calibrar el grado de acierto de la nueva ley al afrontar estas cuestiones. El proyecto inicial, pese a su confesado dualismo, era notablemente incoherente y dubitativo. Algunas de sus manifestaciones de más bulto se fueron puliendo en el debate, pero su línea básica se mantiene: se evita cualquier rasgo que presente a los derechos del autor como derechos fundamentales constitucionalizados, tanto en su configuración como en su protección jurisdiccional; predomina el tratamiento de los derechos de explotación, mientras que los derechos «morales" —o el "Derecho moral», como llamativamente se le titula ${ }^{147}$ - parecen reconocerse de un modo forzado y postizo.

El debate de las diversas enmiendas presentadas a su Libro primero ayudan a valorar la situación. Aparte de que la tónica habitual en las Legislaturas de mayoría socialista haya convertido en fenómeno excepcional la aprobación de cualquier enmienda, el trato recibido no deja de ser significativo.

Por ejemplo, el artículo inicial arrancaba con la expresión «El autor», indicando cómo adquiría la «propiedad intelectual» de la obra por el solo hecho de su "creación». El intento de encabezarlo con una alusión monista al «ejercicio del derecho a la producción y creación, literaria, artística..." -en clara referencia al artículo 20 de la Constitución-y de distinguir luego entre «los derechos personales del autor» $y$ «los patrimoniales de propiedad intelectual ${ }^{148}$ —estableciendo un juego de supremacia de los derechos de los autores sobre la explotación que ellos $u$ otras personas pueden llevar a cabo - no encuentra eco. Para colmo, se produce un cambio de redacción que hace encabezar el texto con una alusión a «la propiedad intelectual», como si se quisiera enfatizar más aún el alcance del título de la ley.

En el artículo segundo vuelve a rechazarse la atribución restrictiva del término "propiedad intelectual» a los derechos patrimoniales -pese a que seria más coherente con el dualismo que el proyecto dice suscribirpero, al menos, se sustituye su definición como “un derecho" (curioso dua-

147 Al respecto $C-128$ (nota 9 ), p. 71.

148 Enmienda n. 131 - Informe Ponencia (nota 29), pág.71 
lismo) «integrado por facultades» personales y patrimoniales, para considerarla integrada por "derechos» ${ }^{149}$ de uno y otro carácter.

No faltaron rectificaciones en la redacción, pero se mantuvo en el artículo 6,2 una condición de problemático cumplimiento ${ }^{150}$. Al menos se evitó que el artículo 9 considerara como obras independientes las «creaciones unitarias, aunque se publiquen unidas", abriendo así insospechadas posibilidades hermenéuticas. Pero es el artículo 14 el que ocupa un lugar central al recoger los "derechos morales", inicialmente presentados como «facultades» de modo quizá significativo ${ }^{151}$.

Que la configuración del contenido de la dimensión patrimonial como "derechos" y la de la personal o «moral" como "facultades» fuera índice de una concepción paleomonista de los derechos del autor como propiedad especial -matizada por el añadido de unas posibilidades «morales" meramente adjetivas - puede parecer empeño en buscar tres pies al gato; pero ya en el debate -quizá porque las metáforas tienden a resultar traicioneras - se defendió un curioso monismo de «desarrollo dualista», basado en el entendimiento de la propiedad intelectual como "sintesis de lo espiritual por adjetivo(sic), y de lo material por el sustantivo, "propiedad"'» ${ }^{152}$. Para eliminar toda duda, el tratamiento penal de estos derechos acabará confirmando la sospecha.

149 Sobre el particular, en el debate: C-128 (nota 9), pp. $4.812 b$ y $4.813 a$. N. PEREZ DE CAStRo plantea como prototipo de monismo uun único derecho integrado por un conjunto de facultades» El derecho de propiedad... (nota 24), p. 220, en clara discrepancia con el mentor del proyecto -cfr. nota (63).

150 El texto originario señalaba farragosamente que «cuando la obra se divulgue en forma anónima o bajo seúdonimo, o signo, el ejercicio de los derechos de propiedad intelectual se presume corresponderá a la persona natural o juridica que la saque a la luz con el consentimiento del autor, mientras éste no revele su identidad". Más bien parece que no se "presume" a quien corresponde el ejercicio de los derechos, sino que se "establece" que corresponderá al que publica la obra; lo que se "presume» es que lo hace responsable de la redacción, reconoce implícitamente el baile de supuestos cuando, para aclarar la curiosa "presunción de titularidad» aludida, señala que "el consentimiento se presume por el hecho de la publicación» - El proyecto de Ley... (nota 63), p. 979a. A lo largo del ajetreado debate -cfr. C-128 (nota 9), p. 4.816- se elimina toda referencia a presunción alguna, con lo que el texto final -que subordina el ejercicio del derecho al consentimiento de un autor desconocido- parece imponer la condición de cumplimiento imposible que pretendia evitar la enmienda n. $137-$ cfr. (nota 29), p. 72.

151 Así se apuntó en el debate - P-30 (nota 8), p. 1.706a. Aunque con frecuencia se los maneje como sinónimos, las «facultades» tienden en sentido estricto a considerarse como ingredientes de los «derechos", o como «manifestaciones modales» de ellos -J. G. STORCH Derecho a la producción... (nota 23), p. 1.178a. Es sintomático que la sentencia de 9 de diciembre de 1985 - (nota 27) - tras señalar en su Considerando (3) que lo que se consagra en el artículo 20 es un derecho genérico e impersonal, añada: «viniendo a proclamar la protección de una facultad". Idénticas enmiendas se aceptaron por dos veces para el articulo 15. 152 El diputado socialista DEL POZO C-128 (nota 9), p. $4.809 \mathrm{~b}$. 


\section{El tratamiento penal como test}

El proyecto inicial incluía forzadamente - como Disposición Adicional Tercera- una notable reforma del Código Penal con honores de ley orgánica. No es la primera vez que se utilizan los últimos vagones de los proyectos para albergar mercancias rechazadas en ocasiones anteriores ${ }^{153}$ o para incluir detalles de especial proyecto legal paralelo, convirtiéndolo en siamés del debatido. Las fundadas protestas por razones formales ${ }^{154}$ acaban siendo atendidas, para poder rechazar asi con más desahogo el carácter orgánico de determinados artículos del proyecto básico... ${ }^{155}$.

La conversión en hermanos gemelos de los antiguos siameses no afectó, sin embargo a su común código genético. El nuevo proyecto presenta claras huellas de la filosofía del anterior ${ }^{156}$, contribuyendo incluso a explicitarla con particular elocuencia. Puestos a suscribir el dualismo - doctrinalmente cuestionado- por el que el proyecto decia optar, el tratamiento penal ofrecía una estupenda ocasión para aprovechar las ventajas prácticas del modelo. Junto a la diversidad de tratamiento de la vigencia temporal de derechos «morales» y patrimoniales ${ }^{157}$, nada justifica tanto el dualismo como la dificultad de encajar la protección penal de los derechos del autor en un Código fiel a los esquemas conceptuales clásicos y obligado, por el principio de tipicidad, a delimitar figuras netas.

${ }_{153}$ En la presentación del proyecto ante el Pleno el ministro SOLANA anuncia por anticipado la aprobación de una enmienda socialista - presentada como Disposición Adicional quinta, aunque acabaría ascendiendo a tercera - por la que se exime del IVA a los autores; lo habian solicitado sin éxito otros grupos en el marco más oportuno del debate de los Presupuestos Generales del Estado - P-30 (nota 8), pp. 1.703a y 1.707a.

154 Resalta el tesón del diputado canario MARDONES SEVILLA que, tras declararse «plenamente de acuerdo en todo su contenido y articulado, excepto en la forma», se considerará satisfecho con su tratamiento autónomo, «al menos en el campo del estructuralismo ortodoxo y de la puridad de la estructura” - P-30 (nota 8), pp. 1.716 b y $1.717 \mathrm{a}$; también $P-51$ (nota 155), p. 3.003a. Un representante de la Minoria catalana, ausente durante todo el debate en Comisión, se personó en ella el tiempo indispensable para congratularse del hecho $-\mathrm{C}-131$ (nota 59), p. $4.969 a$.

155 Muy especialmente el de los artículos 14 y 123. Por otra parte, el Parlamento de Andalucia (con fecha 22 de mayo de 1987 y número de registro 1.075), al no admitir a trámite una proposición de ley relativa a instalación, vigilancia y control de vídeos comunitarios, no lo considera competencia de la Comunidad Autónoma, remitiendo a la jurisprudencia del Tribunal Supremo que, por entenderla «cuestión afecta al ejercicio de los derechos reconocidos en el artículo 20 de la Constitución española», considera que deben ser «regulados a través de una ley orgánica estatal»; la relación del artículo 90 de la ley con dicho supuesto es poco dudosa. El Informe de la Secretaria General...-(nota 84), pp. 20, 21 y 25- sólo propuso «desglosar la Disposición Adicional Tercera del Proyecto de Ley de Propiedad Intelectual, que pasaria a convertirse en una ley independiente, con carácter orgánico" en algunos de sus artículos. Ello dio pie a nuevo debate ante el Pleno - CG-DSC, III Legislatura. Pleno y Diputación Permanente, $\mathrm{n}^{\circ} 51$ de 21 de mayo de 1987 (en adelante $P-51$ ).

${ }_{156}$ Al respecto en el debate, $C-131$ (nota 59), p. 4.970 a y $P-51$ (nota 155), p. $3.003 b$.

157 Cir. A. DIEZ, El derecho de autor... (nota 38), t. l, pp. 156 y 157. 
Una vez declarada la discutida opción dualista, habría sido sensato intentar capitalizar sus ventajas. Ello habría llevado a proponer un desglose del encaje constitucional de los derechos del autor, remitiendo los «morales» al artículo 20 - con rango y protección reforzada de derecho fundamental - y vinculando los patrimoniales el artículo 33 , sin necesidad de recurrir a la cortina de humo del artículo 149. En la esfera penal, cabría haber tipificado las lesiones de los derechos «morales" en vecindad con los delitos contra el honor, u otros protectores de bienes personales, reservando el encaje en el Título XIII del código a las lesiones de los derechos de explotación. La indudable distorsión que ello implica para la consideración de los derechos del autor no sería, a fin de cuentas, sino consecuencia del dualismo ya suscrito. Por otra parte, su abandono no deja de producir de rechazo consecuencias en la sistemática del propio Código; al obligarle a mezclar la protección de bienes personales y patrimoniales, dando paso a figuras anómalas ${ }^{158}$.

Un congruente dualismo parecia ser el objetivo del Dictamen elaborado por el Senado dos años antes, cuando proponía que «las leyes penales debieran incluir la tipificación de las conductas relativas a la conculcación de la titularidad y la integridad de los Derechos de Autor en su doble vertiente de derechos morales intrasnsmisibles y patrimoniales transmisbles» ${ }^{159}$. Sin embargo, la vía seguida fue bien distinta.

Para empezar, la alusión a los Derechos del Autor desaparece del rótulo de la sección del Código sometida a reforma, para ser sustituida por otra que empareja la propiedad intelectual con la industria; coherente actitud desde una perspectiva dualista, a condición de que los elementos personales encontraran tratamiento en sección distinta. Muy otro fue el resultado. Los tipos se configuran en torno a la lesión de bienes patrimoniales, mientras que las agresiones a los derechos «morales» se convierten en meras circunstancias agravantes ${ }^{160}$. La consideración de los derechos "morales" como añadido adjetivo u ornamental al cuerpo sustancial de una peculiar propiedad cobra así, más allá de la metáfora, carta de naturaleza.

${ }^{158}$ Así el ánimo de lucro, que caracteriza a casi todos los tipos incluídos en dicho Título, se convierte ahora en mera agravante, reproche que tarda en ser comprendido por el ocasional ponente socialista $-C-131$ (nota 59 ), p. $4.971 \mathrm{~b}$; también $P-51$ (nota 155), p. 3.004a.

159 Se señalaba en él, igualmente, cómo «los llamados derechos morales no son objeto de protección penal sino a costa de la aplicación de normas peregrinas" - Propiedad intelectual (nota 2), pp. 409b y $407 a$.

${ }_{160}$ Tal ocurre en el artículo 554 bis, b) 1., equiparándose al ánimo de lucro conductas como «infringir el derecho de divulgación del autor", "usurpar la condición de autor sobre una obra o parte de ella o el nombre del artista", "modificar sustancialmente la integridad de la obra sin autorización del autor"... El rechazo de este planteamiento es tan continuo como ineficaz P-30 (nota 8), pág. 1707a; C-131 (nota 59), pág. 4971b; P-51 (nota 155), pág. $3003 \mathrm{~b}$ - hasta los últimos compases del debate, al volver al Congreso las enmiendas introducidas por el Senado -CG-DSC, Iłl Legislatura, Pleno y Diputación Permanente, n. 69 de 27 de octubre de 1987 (en adelante P-69), pág. 4170a. 
El tratamiento penal de los Derechos del Autor acaba reflejando un paleomonismo más o menos edulcorado.

Por lo demás, entre otras cuestiones de detalle, resaltaron las críticas dirigidas desde ópticas diversas al tratamiento poco matizado de las conductas contempladas. Para unos, se olvida el carácter de última «ratio» del ordenamiento penal, mediante la transformación en ilicitos penales de meras infracciones; otros sugieren tipificarlas como faltas, antes de tratar como delito actos de intencionalidad poco contrastada ${ }^{161}$.

\section{Debate fundamental}

La principal novedad en la tramitación parlamentaria del proyecto, interrumpida por el precipitado tránsito de la Segunda a la Tercera Legislatura, fue la presentación de dos enmiendas a la totalidad. Se hacía así obligado el debate ante el Pleno del Congreso de una prolija ley, destinada en principio a ser tramitada en la intimidad de una Comisión. La novedad no dejó de ser llamativa, porque el proyecto inicial -libre de toda propuesta de veto - habia sido ya informado por la Ponencia, asumiéndose buen número de enmiendas. Habian continuado, por otra parte, las negociaciones del Gobierno con grupos profesionales afectados, no siempre coronadas por el éxito ${ }^{162}$; pero todo hacia presumir un reestreno parlamentario de puro trámite. Una de las enmiendas a la totalidad del proyecto registraba deficiencias en el respeto de las variadas lenguas ${ }^{163}$ y en la articulación de las competencias autonómicas; su retirada trasladó probablemente dichas cuestiones, más que al debate en Comisión -en la que el Grupo enmendante no compareció- a la trastienda de la negociación política. La enmienda mantenida apuntaba a los aspectos decisivos de la fundamentación de los derechos del autor y al consiguiente reforzamiento

${ }_{161} P-30$ (nota 8 ), p. 1.710 a; $C-131$ (nota 59 ), p. 4.907 b y $P-51$ (nota 155), p. $3.004 a$. El diputado de AP HuIDOBRo defendió con especial tesón su tipificación como falta; al final sólo se acepta el añadido de una pena de inhabilitación especial para el ejercicio de la profesión y un nuevo artículo sobre responsabilidad civil $-\mathrm{C}-131$ (nota 59), pp. 4.969b y $4.971 \mathrm{a} ; P-51$ (nota 155), pp. 2.999a y 3.000 a. Interesante al respecto la sentencia del Tribunal Supremo (2. $\left.{ }^{a}\right)$ de 13 de junio de 1987, de la que fue ponente el magistrado JIMENEZ VILLAREJo, como expresiva del "status quaestionis" en los últimos momentos de vigencia del texto ahora reformado.

162 Especialmente "gráfica" resultó la protesta de los fotógrafos de prensa, al comprobar queno se atendían las enmiendas - defendidas por diversos grupos- que proponían para ellos un tratamiento similar al de los redactores $-C-128$ (nota 9), pp. 4.846 b y 4.858 ; C131 (nota 59), p. 4.952. Su apadrinamiento final por el grupo socialista del Senado acabaría convirtiendo en razonables tales pretensiones $-S-46$ (nota 8 ), p. $1.771 \mathrm{~b}$.

${ }_{163}$ J. M. CHico OrTiz alude a algunos de los problemas prácticos planteados por nuestro plurilingüismo - Presente y futuro... (nota 30), p. 27. Ante el Pleno se plantea el problema del posible bloqueo de una obra en "otra lengua del Estado que no sea el castellano", por no estimar oportuno publicarla el editor propietario de los derechos $-P-30$ (nota 8 ), p. 1.712a. Al primitivo artículo 61 se presentan cinco enmiendas adicionales, planteándose por la Ponencia una posible transacional -(nota 29), p. 149 que se aprueba $-C-128$ (nota 9 ), p. 4.862- añadiendo dos nuevos epígrafes al ya artículo 62 . 
de su protección. Como consecuencia, se plantea de inmediato la necesidad de que el proyecto se tramitara con rango de ley orgánica ${ }^{164}$.

El debate afrontará el doble problema ya conocido: si cabe considerar incluídos a los derechos del autor en el artículo 20 de la Constitución, y si dicho artículo - sea cual sea su contenido-goza de la protección jurisdiccional encauzada hasta el momento por la ley 62/78. Las respuestas a esta doble cuestión van abriendo un variado panorama.

1. Una primera posibilidad es negar toda relación entre los derechos del autor y la libre creación del artículo 20. Esto exige desmontar los sólidos argumentos que los debates constitucionales ofrecen, a costa de formulas notablemente imaginativas ${ }^{165}$. La ley de "propiedad intelectual» no desarrollaría, pues, el contenido de un artículo en el que no está contemplada, sin perjuicio de que pueda servir instrumentalmente a la realización más efectiva de su auténtico contenido ${ }^{166}$. Ello llevaría a excluir el carácter orgánico del proyecto y privaría de relevancia a la respuesta a la segunda cuestión: se incluya o no al artículo 20 entre los que ya gozan de protección reforzada, ello no beneficiaria a los derechos del autor.

Esta opción deja pendiente cuál sería su encaje constitucional sustitutivo. La posibilidad más obvia es recurrir al artículo 33, dándole así coherencia plena a la terminología «propiedad» intelectual ${ }^{167}$. La exclusión de toda protección reforzada derivaría entonces del propio artículo 53.2 de la Constitución. Dos cuestiones quedarian por resolver. La ya señalada del problemático juego de los derechos morales, con un fundamento tan netamente patrimonial, sólo admite dos soluciones: ignorarlos, llegando a una drástica equiparación de propiedad intelectual e industrial, u optar por un dualismo ortodoxo que les busque fundamento por otra vía, como la del

164 En la sentencia de 30 de mayo de 1987, sobre el caso Sistiaga - (nota 113), p. 11bse cita la enmienda presentada por el PDP al artículo 123, para añadir que, "alertada por esta enmienda, la Ponencia recapacita" sobre el problema. De hecho, aunque en el Informe de la Ponencia se alude a la cuestión al comentar dicho artículo —-(nota 29), p. 153-, venía ya exigida por la enmienda a la totalidad y anteriores enmiendas al articulado, como se pondrá de relieve desde el arranque del debate -C-128 (nota 8), p. 4.806b. La petición de la Ponencia para que la Mesa se pronunciase al respecto se resuelve, por acuerdo de 5 de mayo de 1987 -BOCG, Serie A n. $14-9$ de mayo de 1987-, en sentido negativo de acuerdo con el Informe de la Secretaria General... (nota 84). Finalizando ya el trámite parlamentario, RocA JUNYENT, portavoz de Minoría catalana - grupo, como se dijo, ausente del debate del articuladoplantea como cuestión de orden el archidiscutido carácter orgánico del proyecto, "que viene a desarrollar, sin lugar a dudas, el artículo 20 de la Constitución» -P-69 (nota 161), p. 4.168b. ${ }_{165}$ Cfr. (nota 87) y (nota 93).

166 Es la postura del Informe de la Secretaría General..., que en ningún caso niega que el proyecto dé paso a un desarrollo directo de los derechos del autor, sino que no considera que tal desarrollo esté cubierto por la reserva de ley orgánica - (nota 84), pp. 3 y 19.

${ }_{167}$ Postura esta suscrita abiertamente en el Informe de la Secretaria General... - (nota 84) - y por el diputado socialista JOVER PRESA, en neta discrepancia con su compañero DEL Pozo -C-131 (nota 59), p. $4.956 \mathrm{a} ; C-128$ (nota 9), p. 4.809 b. 
derecho al honor ${ }^{168}$. Por otra parte, la dimensión social de los derechos del autor cobraria desde este fundamento un matiz peculiar, dada la invocación constitucional a la función de la propiedad.

2. Una segunda postura lleva a entender que, aun teniendo su fundamento en el artículo 20 , no cabe considerar que el tratamiento de los derehos del autor en el proyecto constituya un «desarrollo directo» del citado precepto ${ }^{169}$. Tal afirmación es difícilmente sostenible, porque equivaldría a sugerir que la acogida de los derechos «morales» en el artículo 14 de la ley, o el reconocimiento de su protección en los artículos 123 y siguientes, no afectan al núcleo esencial de los derechos del autor. Por otra parte, extender a ellos una actitud de indefinición constitucional, similar a la dictaminada por el Tribunal Constitucional sobre la televisión privada. ${ }^{170}$, supone abandonar toda dimensión de "desarrollo" constitucional, para situarnos en el amplio campo de las opciones disponibles para el legislador.

En lo relativo a la protección reforzada nos veriamos remitidos a una interpositio legis/atoris que aboca a la perplejidad. En medio de un amplio debate doctrinal sobre la posible extensión a los supuestos del artículo 20 de la "provisional» ley 62/78, el artículo 123 se limita a incluir un «sin perjuicio de otras acciones que le correspondan», que parece todo un monumento a la inhibición. Si condicionar a la actividad del legislador la protección de supuestos constitucionales parece ya debilitarlos, aún más preocupante resulta encontrar tal falta de sensibilidad por parte del legislador ante un problema acuciante en la práctica, en materias que - por el momento- resultan abordadas de cien en cien años.

Estas dos primeras posturas coinciden en su respuesta negativa a una pregunta inaplazable: ¿por qué no una ley orgánica? En este punto se hace inevitable una breve digresión, para arrojar luz sobre una tónica mantenida sistemáticamente por la mayoría parlamentaria de la Tercera Legislatura. Una primera explicación de sus resistencias a conferir rango de ley orgánica a determinados proyectos invitaría reconocer todo un alarde de "fair play" en su posible voluntad de secundar la jurisprudencia constitucional, que aconseja una interpretación restrictiva a la reserva prevista en el artículo 81,1 de la Constitución ${ }^{171}$. Su abuso permitiria a un grupo parlamentario que dispusiera del quorum preceptivo -como ocurre con el

${ }_{168}$ Asi lo hace J. G. STORCH, que plantea el derecho «moral» como «una modal manifestación del derecho al honor del autor", que sería "subsumible en la protección constitucional del artículo 18.1 de la Constitución»-derecho a la producción... (nota 23), p. 1.180.

${ }_{169}$ Parece suscribirla uno de los ponentes socialistas, cuando admite que los derechos del autor tienen su fundamento en el articulo 20, "pero me he cuidado mucho de decir que era un fundamento indirecto, no un fundamento directo" $-\mathrm{C}-128-$ (nota 8), p. 4.811a.

${ }_{170}$ A ella se alude por unos y otros en el debate $-C-128$ (nota 8 ), pp. 4.808 b y $4.809 a$.

171 Esta es una de las líneas argumentales del Informe de la Secretaría General... - (nota 84), pp. 18 y 24 en su denodado intento por justificar la exclusión del carácter orgánico del proyecto. 
socialista en esta Legislatura - imponer su propia óptica ideológica en leyes dotadas de tan particular rigidez que haria muy dificil su modificación, una vez alterada electoralmente la relación entre las fuerzas parlamentarias.

Junto a esta posible explicación -especialmente encomiable dada la inusual mayoria parlamentaria concentrada por un solo grupo- algunos apuntes doctrinales dejan abierta una sospecha que, para algunos, se confirmaría durante el debate. Se habia señalado, en efecto, que la referencia del artículo 20.4 de la Constitución a las leyes de desarrollo no podía entenderse «como una claúsula que habilite al legislador ordinario para atribuir a los órganos de la Administración Pública competencias gestoras o tutelares del ejercicio de los derechos considerados" ${ }^{172}$. Se había observado incluso, de manera más directa, cómo los primeros borradores de la futura ley introducian «algo que viene a estar en contradicción con el artículo 20 de la Constitución, atribuyendo facultades de intervención al campo gubernativo o administrativo" ${ }^{173}$.

Llama la atención, en efecto, cómo un texto legal, prolijo en ocasiones hasta la exasperación, recurre a fórmulas dilatorias a la hora de abordar problemas especialmente polémicos. No parece que se pretendiera ganar tiempo - al cabo de cien años y la propina de un doble trámite parlamentario - sino más bien tener las manos libres en una negociación sin intermediarios parlamentarios ${ }^{174}$. Actitud esta que sintoniza con la línea intervencionista que el proyecto sigue en cuestiones tan decisivas para el libre juego de los derechos del autor como la configuración de las entidades de gestión ${ }^{175}$. Quede, pues, constancia de esta menos encomiable hipótesis explicativa de tan tenaz línea de conducta. Pero volvamos al hilo de nuestro discurso...

3. Resta como tercera posibilidad considerar incluído en el artículo 20 el núcleo esencial de los derechos del autor, con el elocuente apoyo de los antecedentes del debate constitucional. Tal contenido exigiría un de-

172 F. J. GAlvez, Comentarios... (nota 84), p. 399. Que esta pueda ser la clave del rechazo del carácter orgánico del proyecto se apunta en el debate, tanto en el Congreso -C128 (nota 9), p. 4.811 b y $4.812 a-$ como en el Senado $-S-47$ (nota 118), p. 1790a.

173 J. M. ChIco ORTIz, Principios y problemas... (nota 3), p. 1.333.

174 Asi ocurre con el discutido problema de las fotocopias, remitido a desarrollo reglamentario - C-128 (nota 9), pp. $4.837 \mathrm{~b}$ a $4.839 \mathrm{a}-\mathrm{o}$ el del control de tirada, sometido a un plazo de desarrollo que no encuentra credibilidad $-C-131$ (nota 59), pp. 4.936a a 4.938a.

175 N. PAZ CANALEJO - Naturaleza juridica de las entidades de gestión colectivas previstas en el Proyecto de Ley de Propiedad Intelectual "la Ley» 3 de abril de 1987 (1682), pp. 1b y $3 \mathrm{~b}$ - señala la actitud elusiva del proyecto y deriva de su carácter no orgánico la imposibilidad de reconocerles naturaleza asociativa. En el debate se denuncia que el proyecto les plantea "trabas excesivas" - P-30 (nota 8), p. $1.718 \mathrm{a}-$ y se llega a sugerir una irónica interpretación hegeliana: "la propiedad como tesis, los derechos morales como antítesis y el Estado al final, intentando controlar a las entidades de gestión»-ibidem p. 1.706a. en el Senado apunta que «no va a haber más entidades de gestión que las que quiera el Ministerio de Cultura" el portavoz del CDS $\rightarrow-47$ (nota 118), p. 1.792a. 
sarrollo directo detallado — como el que se lleva a cabo en algunos artículos de la nueva ley- sujeto, por ello, obviamente a la reserva de ley orgánica prevista en el artículo 81,1 de la Constitución. No se trataría, pues, de instalar por vía legislativa apoyos instrumentales que apuntalen desde fuera la eficacia práctica de unos contenidos constitucionales; sino de dar paso, sin más, al desarrollo directo de las exigencias implícitas en tales contenidos ${ }^{176}$.

En cuanto a la segunda cuestión, la interpretación más favorable a la protección de los derechos fundamentales en juego lleva a reconocer ${ }^{177}$ aplicable a los ámbitos civil y penal — sin reducirla al contencioso-administrativo- la ampliación del campo de juego de la ley 62/78. El debate a que esta interpretación se ve sometida en la práctica -obligándole a refugiarse en votos particulares o demandas inatendidas por razones periféricas- exigia una actitud más explicita de la nueva ley. Su tozudo silencio, pese a las enmiendas presentadas para hacer más expresa esta conexión, podría tener consecuencias tácitamente excluyentes.

Los mecanismos procesales contemplados en los artículos 123 y siguientes de la nueva ley repiten, por otra parte, el fenómeno ya advertido al articularse la protección penal de estos derechos. Los supuestos que incluyen se refieren fundamentalmente a la protección de derechos de explotación; la referencia a la indemnización por «daño moral» del artículo 125 tiene el mismo aire subordinado de las agravantes de los tipos penales, ya que las "actividades ilícitas" aludidas en el artículo anterior como ocasión de intervención directa consisten en «explotación», «comercio», «reproducción» o «comunicación no autorizada», y las medidas prácticas se centran fundamentalmente en el control de los «ejemplares». Intentar introducir en dicho marco casos como el de Pablo Serrano sería esfuerzo inútil. Igualmente las medidas cautelares previstas en el artículo 126 consisten en intervención de «ingresos», suspensión de “reproducción, distribución y comunicación" y secuestro de «ejemplares" o material de reproducción. Difícilmente estas nuevas vías de protección pueden sustituir con

${ }^{176} \mathrm{Al}$ respecto $\mathrm{C}-128$ (nota 86 ), p. 4.807 a.

17 Cfr. C-131 (nota 59), pp. $4.953 \mathrm{~b}$ y $4.954 \mathrm{~b}$. Suscribe ambas respuestas el voto particular de la sentencia de 9 de diciembre de 1985. Similar linea argumental se desarrolla de modo exhaustivo en la Demanda - (nota 7) - del recurso de amparo subsiguiente. TOMÉ GARClA considera incorrecta la dimensión restrictiva que adopta la ley 62/1978; a su juicio, tiene como consecuencia que, por el momento, tal protección sólo quede disponible para todos los derechos en vía contencioso-administrativa -Protección de los derechos humanos ante los tribunales ordinarios Madrid 1987, pp. 171 y 173. También suscribe esto último J. V. LORENZO JIMÉNEZ en Las garantías jurisdiccionales penal y civil en la Ley de Protección Jurisdiccional de los Derechos Fundamentales de la Persona "Revista de Derecho Procesal» 1987(2), p. 295. No faltan alusiones a la ley $62 / 78$ en otras enmiendas, como la $n .^{\circ} 126$ del CDS, que pretendia extender su alcance a las autorizaciones de las entidades de gestión previstas en los articulos 132 y $133-C-131$ (nota 59 ), pp. 4.962 b y $4.963 a$; $S-47$ (nota 118), pp. 1.790 a y 1.792 b. 
eficacia la falta de una alusión expresa a los cauces de protección jurisdiccional de los derechos fundamentales ${ }^{178}$.

\section{La creación artistica como actividad social}

La consideración de la creación artística como la apertura de un proceso de comunicación la dota ya en su raíz de una dimensión social. Surge así un campo, tan interesante como resbaladizo, en el que no podremos profundizar. Dejaremos, al menos, apuntados dos aspectos. El arte no es mero desahogo personal arbitrario; ello pone a cubierto de la dinámica disparatada a que podría dar lugar la apelación indiscriminada a presuntos derechos «morales» sobre problemáticas «obras de arte» ${ }^{179}$. Por otra parte, no cabe remitir al simple juego del mercado el juicio sobre el valor artístico, como sugeriría expeditivamente un «análisis económico del derecho".

Cuando, por el contrario, el arte se plantea como mera afirmación individual, susceptible de convertirse en modo de adquisición de una propiedad, la dimensión social o no existe o ha de introducirse a través de la vía seguida por la doctrina para atemperar su individualismo: el resalte de su «función social» ${ }^{180}$.

Interesante campo de prácticas sobre esta dimensión social de los derechos del autor lo ofrece el tratamiento de su duración. Desde una perspectiva individualista, como la que caracterizaba el tratamiento de la propiedad en el pasado siglo, la aspiración a un carácter perpetuo de la propiedad intelectual encuentra fácil justificación: «La propiedad, o es justa, y entonces no termina nunca, o es injusta, y en este caso no debe comen-

178 La sentencia de 30 de mayo de 1987 sobre el caso Sistiaga - (nota 113), pág. 11bno parece haberlo interpretado así, al entender que la enmienda 194 pretendia diferenciar libre creación y propiedad intelectual, cuando en realidad aspiraba a enlazar gradualmente el núcleo fundamental y el desarrollo legislativo de los derechos del autor. Tanto esta enmienda como las presentadas sobre el tratamiento penal de estos derechos acabarian siendo retiradas por el portavoz del PDP en el Senado sin mayores explicaciones - $S-46-$ (nota 8 ), pág. 1765a y S-48 (nota 118), pág. 1795b.

179 Las ventajas pragmáticas del sistema anglosajón del «copyright» sobre el que considera existentes los derechos sobre una obra «por el solo hecho de su creación» (artículo 1 de la nueva ley) son tan obvias como teóricamente cuestionables. Los mismos uderechos morales» no quedan en su juego exentos de condicionamiento social. La aceptación por la Ponencia de la enmienda $n .{ }^{\circ} 150$ del artículo $14,5 .^{\circ}$ refleja tal sensibilidad $-\mathrm{C}-128$ (nota 9 ), p. $4.825 a$.

${ }_{180}$ Contemplada ya en el epigrafe 2 del propio artículo 33 de la Constitución y reforzable en relación al artículo 44. Al respecto C. Alvarez Romero, La Constitución... (nota 2), p. 82. Al segundo de estos artículos se remitió el diputado socialista Joven - C-128 (nota 9), p. $4.840 \mathrm{~b}$. 
zar» ${ }^{181}$. La consideración de la radical dimensión social de la creatividad artística favorece su paso, en un plazo moderado, a la pública disponibilidad; se confía en que esa ausencia de trabas facilitará la difusión de la obra, potenciando con ello una comunicación socialmente enriquecedora. Cuando, por el contrario, lo «social» se entiende en clave estatalista, se propone un simple cambio de propietario, no viendo en el libre juego de los agentes culturales sino una injustificada fuente de lucro. Llevando esta postura al extremo, ninguna limitación temporal tiene sentido: el único "propietario intelectual", antes y después de la muerte del autor, sería el Estado ${ }^{182}$. Posturas más patrimonialistas, por último, coincidirán en proponer un mantenimiento del prolongado plazo vigente ${ }^{183}$.

No menos presente se muestra la dimensión social de los derechos del autor cuando se tiene en cuenta su vertiente «moral». El Convenio de Berna, que le da carta de naturaleza, la vincula continuamente al "honor», la «reputación», el «renombre» o la «estimación pública», y deja tal huella en la legislación posterior, proyectos españoles incluídos ${ }^{184}$. No tiene nada de extraño, pues, que se haya apelado entre nosotros al derecho al honor como cauce para ampliar una exigua protección, repitiendo, paradójicamente, la experiencia anglosajona ${ }^{185}$.

181 DanVILA, dirigiéndose A las Cortes -Propiedad intelectual (nota 2), p. 340a. En consecuencia, el articulo 2 del proyecto de 1879 la consideraba "perpetua», pero dicha alusión desaparece en el posterior dictamen de la Comisión, para señalarse ochenta años «post mortem»-ibidem, pp. $341 \mathrm{~b}$ y $351 \mathrm{a}$.

${ }_{182}$ Significativa la intervención del diputado de Esquerra Catalana EsPASA OLIVER, que sólo entendería una limitación temporal si su fruto "revirtiere en favor de toda la sociedad, por ejemplo, en favor del Estado", mientras que perdería sentido cuando "se benefician otros del ámbito estrictamente comercial» - P-30 (nota 8), p. 1.717b. En línea similar su compañero de grupo, el comunista GARCIA FONSECA, propondrá un «canón de dominio público» a pagar por las editoriales -C-128 (nota 9), p. 4.851. Es Ilamativa, por otra parte, la insistencia del ministro SOLANA y diputados afines en resaltar la dimensión social de la exención del IVA -ibidem, pp. $1.703 a$ y $1.708 b-$, queriendo quizá evitar que se viera en ella una concesión a uno de los colectivos con los que se venia buscando un acuerdo.

${ }_{183}$ Tanto HuIDOBRo, diputado de AP: «el derecho de explotación es fundamentalmente el derecho patrimonial de la propiedad intelectual, el derecho de autor» $-C-128$ (nota 9), p. 4.839b; también P-30 (nota 8), p. 17.19a-como el catalán LOPEZ DE LERMA - P-30 (nota 8), p. $1712 \mathrm{~b}$ - coinciden en rechazar el paso de ochenta a sesenta años, argumentando que la legislación extranjera tiende a ampliar el mínimo de cincuenta años previsto por la Unión de Berna. Mantienen posturas similares los portavoces de ambos grupos en el Senado $\$-46$ (nota 8), p. 1.769 .

184 Véanse las glosas de N. Pérez Serrano en El derecho moral... (nota 26), pp. 13, 14, 16 y 27 . Ya el proyecto de 1934, en su artículo 19, vincula derecho moral de autor y perjuicio "para su honor y prestigio" —Propiedad intelectual (nota 2), p. 396a. También la nueva ley, en su artículo $14,4 .^{\circ}$, se refiere al «perjuicio a sus legítimos intereses o menoscabo a su reputacion".

105 J. M. CHICO ORTz había aludido incluso a la posibilidad de una referencia expresa de la nueva ley a la orgánica de 5 de mayo de 1982 sobre la protección del derecho al honor -Principios y problemas... (nota 3), p. 1.335. La ya citada enmienda n. 194 al articulo 123 buscaba, en la alusión al derecho al honor, una vía alternativa para superar la posible debilidad de protección derivada de esas interpretaciones restrictivas que excluian de la cobertura de la ley 62/1978 la libre creación artística. Se repite con ello la tarea que debió llevar 
La realidad de la creatividad artística como apertura de un proceso de comunicación en la vida social condiciona, por último, el concepto mismo de autor. Mientras que un planteamiento meramente mercantil llevaria a la equiparación de las personas jurídicas con las físicas a la hora de identificar «autores», una dimensión más antropológica del problema lleva a reservar tal carácter para las personas físicas, de modo individual o colectivo, como hace la nueva ley ${ }^{186}$. No se muestra, sin embargo, tan coherente a la hora de catalogar a los titulares de los llamados derechos conexos o afines.

Esta confusa y abigarrada terminología arranca de la equiparación que por motivos pragmáticos, se establece en documentos internacionales - como la Convención de Roma de 1961 - entre categorias tan diversas como "artistas, intérpretes o ejecutantes", «productores de fonogramas» y "entidades de radiodifusión». Que todos tengan sus legítimos derechos es una cosa y otra, bien distinta, que se les siga equiparando, como hace en su libro segundo la nueva ley, dentro del imaginativo rótulo «Otros derechos de propiedad intelectual».

En concreto, la primera de estas categorias engloba a personas que ejercen su creatividad artística, continuando con ella -a veces de modo decisivamente enriquecedor - el proceso de comunicación incoado ${ }^{187}$. Nos hallamos, pues, ante un tipo peculiar de «autores», que en ocasiones son los que en realidad protagonizan determinadas creaciones artísticas. Equipararlos a quienes se limitan a aportar elementos técnicos para instrumentar la difusión o publicación de una creación ajena no parece tener mucho sentido ${ }^{188}$. El reconocimiento de la condición de autor a los titulares de algunos de estos variopintos derechos conexos no dejará de tener trans-

a cabo la jurisprudencia inglesa para superar el enfoque mercantilista propio del sistema de "Copyright» - cfr. A. DIEZ, El derecho de autor... (nota 38), t. I, p. 158.

${ }_{186}$ Así lo resalta la propia Memoria del proyecto... - (nota 1), p. 4-y queda reflejado en los artículos 5 a 8 de la ley. Sobre algunas consecuencias de dicha opción J. M. CHICO OrTIZ, Presente y futuro... (nota 30 ), p. 14.

${ }_{187}$ H. BAYLos traza oportunamente una diferencia básica entre las obras intelectuales, susceptibles de "actualización creativa» y las industriales, que sólo pueden dar paso a una "realización ejecutiva y neutra» - Tratado... (nota 17), p. 85. Cfr. También R. REMBE, Autores y artistas intérpretes o ejecutantes: a igual contribución igual protección, «Boletín del Derecho de Autor» 1986(4), pp. 33-35. La ley no contempla a los autores de estas "obras derivadas" entre los sujetos de los derechos de autor, sino que se limita a contemplarlas reduplicativamente, en sus artículos 11 y 21, como objeto de la propiedad intelectual; aunque no se prive de aludir al «autor» de las transformaciones creativas. D. ESPIN CÁNOVAS justifica esa exclusión con el discutible aserto de que en su actuación "no existe verdadera "creación intelectual" " -El proyecto de Ley... (nota 63, p. 982b.

${ }_{190}$ E. SERRANO ALONSO resalta con acierto la necesidad de un tratamiento diverso; sin embargo, su negación de la impronta creativa que -para bien o para mal- tienen las traducciones puede resultar injustificada en más de un caso-Sugerencias... (nota 25), pp. 63, 73 y 74 ; al respecto $C-128$ (nota 9 ), p. 4.813 b. 
cendencia práctica ${ }^{189}$ a la hora de posibilitarles el ejercicio de los derechos «morales», a cuyo disfrute la nueva ley no parece darles opción.

\section{Los Tribunales se quedan en la superficie}

La primera etapa de su contencioso dejó a Pablo Serrano con su “Viaje a la luna...» varado en el fondo del almacén, gracias a un Tribunal con una concepción paleomonista de los derechos del autor. Al final de la segunda etapa sus derechos quedaban «...en el fondo del mar», y con ellos las llaves de la protección efectiva de los derechos del autor, gracias a un Tribunal que -ipara no mojarse? - se declaraba imposibilitado de descender al fondo de su problema. Nadie, sin. embargo, -y éste era para él el auténtico fondo de la cuestión - le habia dicho todavía que sus pretensiones no merecieran el reconocimiento de la justicia. Su viuda recogeria la antorcha, para dar paso a una tercera etapa, ante el Tribunal Constitucional, con la fundada esperanza de que éste amparase al fin los derechos de los autores, a fondo.

Pero, ¿no había abordado el 9 de diciembre de 1985 el Tribunal Supremo, realmente, el fondo de la cuestión? Rechazó el primer motivo del recurso, "al no justificar debidamente que el procedimiento seguido era el adecuado, lo que impide el examen del segundo referente al fondo del asunto" ${ }^{190}$. Una vez más, se pone de relieve que la distinción entre fondo y forma suele plantear con frecuencia ineludibles problemas de fondo.

El Tribunal no se limita a considerar inviable el procedimiento de la ley 62/78 para proteger los derechos del autor, sino que -obligado a fundamentar su postura- aborda problemas tan de fondo como el de distinguir entre un derecho genérico a la creación y otro «del autor» sobre la obra creada, negando que éste se incluya en el artículo 20. Su misma afirmación de la necesidad de una intervención legislativa, «sobre todo por lo que respecta al procedimiento jurisdiccional» deja entrever que el otro punto sometido a debate - «la configuración del instituto "derecho de autor"»lo da por prácticamente resuelto; en efecto, una.ley puede desarrollar el contenido de un derecho constitucional, pero difícilmente podrá introducir en la Constitución un derecho del autor sobre ese «resultado» de su obra,

189 Aunque al diputado socialista DEL POzo le parece «un debate teórico de una cierta gracia", al discutirse la enmienda $n .^{\circ} 134$ al articulo 5.1 , que proponía considerar autor a todo el que «interviene creativamente" en la realización de una obra de arte $-C-128$ (nota 9), pp. 4.814-4.815.

${ }_{190}$ Considerando (8). 
que drásticamente se habia situado fuera de su ámbito. Para más de uno ${ }^{191}$ la respuesta de fondo no había podido ser más expresiva.

Ni siquiera sobre la otra alternativa aludida como vía de protección -el derecho al honor del artículo 18-guarda el Tribunal silencio, ya que traza también una neta divisoria entre los derechos «de la personalidad» y los derechos del autor sobre el «resultado» de su obra ${ }^{192}$.

La demanda solicitando el amparo del Tribunal Constitucional perfila netamente un planteamiento bien diverso. La Constitución brinda ya a los derechos del autor ese fundamento positivo que la lejana sentencia de 21 de junio de 1965 echaba en falta. Su artículo 20.1.b «supone la constitucionalidad del núcleo del derecho de autor", no sólo como freno oponible a la intervención de los poderes públicos, sino incluso para que «operara en relaciones entre particulares" ${ }^{193}$. Presente como derecho fundamental en el citado artículo, sin necesidad de «interpositio legislatoris", tampoco será ésta necesaria para arbitrar la protección reforzada del artículo $53,2{ }^{194}$; bastaria con interpretar del modo más favorable a los derechos fundamentales la ampliación que la Ley Orgánica del Tribunal Constitucional lleva a cabo del campo de juego de la ley $62 / 78$-o incluso aplicar tal criterio hermenéutico a esta misma- para encontrar fundamento juridico a la solución del problema planteado. Tal protección se extendería, de acuerdo con los documentos de Naciones Unidas ${ }^{195}$, a «los derechos moral y patrimonial de autor» en su doble dimensión.

Especialmente relacionada con la dimensión comunicativa de la creatividad artística arriba expuesta nos parece la alusión, como fundamento del amparo, a la «persistencia de la situación»; el desmontaje de la obra, lejos de suponer un «agotamiento de efectos de los actos lesivos» implicaría una "violación actual» ${ }^{196}$ de los derechos del autor. Si se en-

191 Por ejemplo, el diputado antedicho, que - aunque aluda a la sentencia con la ìmprecisión propia de una cita al hilo del debate- se funda en ella para apuntar que la ley, al tratar de los derechos del autor, se ocupa del «resultadon y no de la constitucional libertad de "creación" - C-128 (nota 9), p. 4.808a.

192 Considerando (5) in fine.

193 Demanda (nota 7), pp. 16b y 23; también E. Garcia de Enterria, Pablo Serrano... (nota 37), p. 31c.

${ }_{104}$ Demanda (nota 7), p. 24b. Se detiene especialmente en una interpretación de la Disposición transitoria 2. ${ }^{a}, 2$ de la Ley Orgánica del Tribunal Constitucional, que no reduzca su ampliación a la via contencioso-administrativa -ibidem, pp. 13b-15b- y en una interpretación de la ley 62/1978 que - tras recordar que la citada ley protege esa "libertad de expresión" de la que la creación artística sería "concrección", según el Tribunal Constitucionalrechaza una versión restrictiva del inciso «en todo caso» de su artículo 11.2 -ibidem, pp. 15b y $16,23 a-24 a$.

${ }_{195}$ Demanda (nota 7), p. 36b. Lamenta la escasa atención prestada al artículo 27.2 de la Declaración Universal de Derechos Humanos y al artículo 15.1.c del Pacto Internacional de Derechos Económicos, Sociales y Culturales, que «no hemos conseguido ver ni siquiera citados ni en la sentencia de $1^{a}$ instancia, ni en la de apelación, ni en la de casación" -ibidem, p. $17 \mathrm{~b}$.

196 Demanda (nota 7), p. 27a; también 30a y 33b. 
tiende que su objeto es un «resultado exteriorizado", destruido éste antes de la Constitución, se excluye toda retroactividad; si se considera, por el contrario que el objeto del derecho del autor es la relación comunicativa que su obra le permite mantener, la interrupción traumática de esta comunicación perdura y constituye un atentado permanente contra un derecho fundamental.

Mientras que el Tribunal Constitucional se ocupaba del caso, sobre los Diputados gravita la responsabilidad de hacer imposible la repetición de la experiencia. Su éxito resulta más que dudoso, dada la configuración de la protección procesal de los derechos morales en el proyecto. Uno de ellos considera "pendiente un homenaje frustrado a Pablo Serrano"; pues para lo que ha servido su tenacidad ha sido, entre otras cosas, para plantear problemas que no están resueltos en el proyecto, por llamativo que eso resulte» ${ }^{197}$. El escultor había comparecido dos años atrás ante la Comisión del Senado ${ }^{198}$ que preparaba un dictamen sobre la situación de los derechos del autor, pero ahora seguía planteando su batalla después de muerto. Las alusiones a su caso se repetirán durante el debate en los más variados contextos ${ }^{199}$.

Se ha producido, pues, un ambiente de mutua expectación. El Tribunal Supremo, al considerar precisa la "estructuración legislativa» de los derechos del autor y del procedimiento jurisdiccional para su ejercicio, alude "al reciente intento de que se tiene noticia de elaboración de un proyecto de ley, en tramitación" ${ }^{200}$. No faltaron, como hemos visto, alusiones de los Diputados a su sentencia, bien para recordar aquellas tareas legislativas que consideraba pendientes, bien para asumir la postura negativa respecto a la constitucionalidad de los derechos del autor, que - sin entrar en el fondo de la cuestión... - había suscrito con notoria claridad. La inminencia de su obligado pronunciamiento del Tribunal Constitucional ${ }^{201}$ aumenta este ambiente de guiños mutuos, ya que nada invita a excluir que este mismo Tribunal esté midiendo las consecuencias que su resolución de un recurso de amparo pueda acabar teniendo sobre el proyecto de ley en pleno trámite ${ }^{202}$; todo ello dentro de un ordenamiento juridico que vio excluido - en pleno debate constitucional- la posibilidad de

$197 \quad P-30$ (nota 8), p. $1.706 \mathrm{~b}$.

198 El 7 de febrero de 1985 - cfr. Propiedad intelectual (nota 2), p. 405a.

199 No sólo insistiendo en la necesidad de responder a su esfuerzo - C-131 (nota 59), p. $4.953 \mathrm{~b}$ - sino incluso a propósito de los derechos del autor de informes jurídicos $-\mathrm{C}-128$ (nota 9), p. 4.846a. El senador socialista BAYONA, al recordar la comparecencia del escultor, esculpe la paradoja: "seguramente se sentiria muy contento de ver aprobada esta ley" - $S$ 46 (nota 8), p. 1.760a. En el cierre del debate en el Congreso volverá a ser aludido $-P-69$ (nota 161),p. 4.170a.

${ }_{200}$ Sentencia del 9 de diciembre de 1985, Considerando (3).

201 Ecos, por ejemplo, en $P-30$ (nota 8), p. $1.709 \mathrm{~b}$ in fine. p. $4.955 b$

202 Asi se dará por supuesto en el debate $-C-128$ (nota 9), p. $4.809 a$; C-131 (nota 59), 
recursos o consultas cautelares al Tribunal Constitucional durante el debate de proyectos legislativos, y que había visto derogar más tarde la incipiente figura del recurso previo de inconstitucionalidad. A nadie puede sorprender cuál acabó siendo el resultado.

\section{La sentencia menos audaz para el lector más inteligente}

El planteamiento de la cuestión hacía concebir esperanzas de que el Tribunal Constitucional, aun no llegando a abordar el fondo de la cuestión, dejara de abordarlo - al menos-con la.misma generosidad de fundamentación que el Tribunal Supremo. Quedaría así despejado, al fin, por voz tan autorizada si los derechos del autor forman parte del contenido de ese derecho de libre creación que él mismo —con afán sistematizadorhabia considerado como una concreción de la libertad de expresión; en consecuencia, quedaria también margen para considerar o no a su disposición el cauce protector de la ley 62/78. Vana esperanza.

En lo relativo a la constitucionalidad de los derechos del autor, el Tribunal -tras recoger en los antecedentes las posturas discrepantes al respecto- nos reitera en los Fundamentos Juridicos información sobre la del demandante, señalando que la Constitución «a su juicio, integra el derecho de autor en el derecho fundamental a la producción y creación artística» ${ }^{203}$.

Tan escasa disposición a entrar a fondo en la cuestión debatida podría quebrar todavía a la hora de tratar los aspectos procesales, como había ocurrido con el Tribunal Supremo. Si éste -para considerar excluído el procedimiento de protección de los derechos fundamentales - se siente obligado a sentar que no considera tales a los derechos del autor, el Tribunal Constitucional no podría - para sentar lo mismo o lo contrario- dejar de decir lo mismo o lo contrario. Tanto más cuanto que el Ministerio Fiscal, con insólito arrojo, no duda en dictaminar la «vulneración del artículo 24,1 de la Constitución, al declarar las sentencias recurridas la inadecuación del procedimiento"; lo cual "es tanto como dejar sin protección un derecho fundamental». Rechaza con ello, por "estricta y literal y desfavorable a la efectividad del derecho fundamental ${ }_{22}{ }^{204}$, la cadena de interpretaciones restrictivas realizada por el Tribunal Supremo a excluir la procedencia de tal vía.

${ }_{203}$ Sentencia del Tribunal Constitucional 35/1987 de marzo, de la que fue ponente el magistrado E. DIAZ EIMIL, fundamento jurídico 3 - «BJC»1987(72), p. 468a.

${ }_{204}$ Ibidem antecedente 7 -(nota 203), p. 467 a. 
El Tribunal Constitucional -tras piropear sin empacho al autor de la demanda de amparo- que «realiza el notable y meritorio esfuerzo de desarrollar una larga y exhaustiva argumentación, apoyada en textos constitucionales y legales y en un minucioso examen de abundantes sentencias de este Tribunal»- se cuida mucho de no decir esta boca es mía. Si el Tribunal Supremo aparentó eludir la cuestión de fondo centrándose en un problema procesal, ahora el Tribunal Constitucional aparentará algo aún más difícil: eludir la cuestión procesal con la excusa de que está obligado a abordar la de fondo. Al considerar el demandante necesario que se apreste a ello, dictamina que su "conclusión es exacta»; pero aprovecha tan feliz circunstancia para no volver a mencionar en su escuálida sentencia la posible vulneración del artículo 24,1 a la que acababa de referirse ${ }^{205}$. Condición previa de la entrada en el fondo le parece el análisis de las circunstancias temporales que se dan en el caso; en dicha dirección orienta el resto de su discurso, con la decidida intención de llevarlo a vía muerta.

A partir de aquí, sentencia tan poco audaz da paso a las interpretaciones más inteligentes, a caballo siempre entre el «quien calla otorga» y el «en boca cerrada no entran moscas».

Los más optimistas ${ }^{206}$ consideran que «dice explícitamente, aunque guizá no con la claridad debida» que las sentencias previas «fueron juridicamente infundadas». Esto no sólo daría por sentado que los cauces de la ely $62 / 78$ son viables para los derechos del artículo 20 de la Constitución, sino que incluso permitiría deducir que los derechos del autor están incluidos entre ellos: la "sentencia reconoce, en efecto, como parecía bastante obvio, que el derecho moral de autor es un derecho fundamental porque lo precisa el artículo 20 de la Constitución". La verdad es que, tras rastrear sus Fundamentos Jurídicos- con la buena disposición de la que estas mismas líneas dan cumplida fe- no es fácil encontrar en ellos rastro alguno de tan paladinos planteamientos.

Más moderados se muestran los que consideran que la sentencia «declara la idoneidad de la vía procesal utilizada para la tutela del derecho reconocido en el artículo 20.1.b", pero lo hace "sin entrar en el tema de si el derecho moral de autor está o no comprendido" en él ${ }^{207}$. Si lo primero fuera cierto, seria bastante difícil - a caballo entre fondo y forma- excluir

${ }_{205}$ Ibidem fundamento jurídico 2 -(nota 203), p. 467b. Menos aún se animará a abordar, tras este quiebro, las alusiones al artículo 20 , e incluso a la protección al honor del artículo 18, que reflejan los antecedentes de la sentencia.

${ }_{206}$ Personificadas en el propio autor de la demanda -E. Garcia de EnTERria, Pablo Serrano... (nota 37), pp. 31a y 32a.

207 Asi lo hace, generosamente, el Informe de la Secretaria General... - (nota 84), p. 14- ayudado quizá por la nula repercusión de tal circunstancia sobre la conclusión denegatoria del carácter orgánico del proyecto. 
lo segundo ${ }^{208}$. El problema radica en que, si el Tribunal llegó a decir lo primero, fue «de una manera sin duda criptica» ${ }^{209}$, y sólo dándola por detectada cabe proseguir derivando consecuencias.

Quedan, por último, los que dictaminan que «afortunada o desgraciadamente, la sentencia del Tribunal Constitucional no aportaba datos nuevos que nos permitiesen tomar una posición clara» al respecto ${ }^{210}$. Esta afirmación lapidaria certificaria una notable oportunidad perdida, por más que las responsabilidades del max-intérprete de la Constitución no fueran las primordialmente implicadas.

Pasando ya a aspectos laterales, sí cabría obtener alguna doctrina. La postura del demandante vuelve a fundarse en el «carácter duradero» de la lesión del derecho «moral», que - aun producida años antes de la Constitución- «se perpetúa» indefinidamente. La otra parte considerará, por el contrario, que «el desmontaje de la obra y su almacenamiento", hace veinticinco años, no «implica la realización o existencia de actos posteriores» ${ }^{211}$ contra los que quepa recurso. Pouríamos considerar, de nuevo, aludida la relevancia de la creación artística como apertura de una comunicación.

Si se opta por la primera postura, nos encontramos - dando por sentado que los derechos del autor están incluídos en el artículo 20- ante un supuesto de aplicación directa de la Constitución, por inconstitucionalidad sobrevenida en el curso de esa lesión perpetuada. Si se opta por la segunda, se pretendería provocar una retroactividad poco respetuosa con la cosa juzgada. De entrada, no se excluye la primera posibilidad, ya que la Constitución «puede afectar a actos posteriores a su vigencia que deriven de situaciones creadas con anterioridad" ${ }^{212}$.

La cuestión vuelve a radicar en si la creación artística es un acto, que da paso a un resultado netamente separable de ella - como apuntaba el Tribunal Supremo- o si, no encierra más bien, una actividad comunicativa poco susceptible de tan tajante disección. El Tribunal Constitucional coincide ahora con el Supremo: nos encontramos ante una «situación ple-

${ }_{208}$ Ello se razona en el debate: si el Tribunal Constitucional «ha aceptado que el Tribunal Supremo considera inaplicable un procedimiento que si era aplicable», es obligado preguntarse «por que era aplicable la ley 62/1978 al caso Pablo Serrano si resulta que sus derechos de autor no tenían rango fundamental en conexión con el artículo 20" - C-131 (nota 59), p. $4.955 \mathrm{~b}$.

${ }^{209}$ C-131 (nota 59), p. 4.954a. Sólo suscribiendo la premisa mayor del citado Informe de la Secretaría General... cabe mantener en frío afirmaciones como las alli expuestas. Tal premisa se asume tambien, pero con dispares conclusiones, en el debate -ibidem, p. 4.955a in fine. Cfr. También C-128 (nota 9), 4.809a, derivando consecuencias positivas de la alusión exclusiva de la sentencia a la extemporaneidad, marginando problemas de fundamento.

210 El diputado socialista JOVER, recurriendo sin duda al plural mayestático - C-131 (nota 59), pp. 4.955a y 4.956a.

${ }_{211}$ Sentencia del Tribunal Constitucional 35/1987, antecedentes 3 y 6 -(nota 203), pp. $466 a$ y $467 a$.

${ }_{212}$ Ibidem, fudnamento jurídico $3-($ nota 203), p. 468a. 
namente agotada», convertida en 1965 en cosa juzgada, sin que existan después de la Constitución actos derivados de ella. Pero el argumento que aporta, para considerar "manifiestamente inaceptable» la perpetuación indefinida de la lesión del derecho del autor a través del no menos indefinido almacenamiento-destrucción de su obra, no se apoya en consideraciones sobre la creación artística; remite, más bien, a cálculos sobre el número de supuestos a los que, «de aceptarse la tesis de la demanda, se abriria el recurso de amparo". Sólo esta equiparación de la indefensión aquí planteada con cualquier otra - remita o no con fundamento a una situación realmente actual - posibilita la argumentación «ad absurdum» en contra de una presunta «retroactividad de grado máximo" ${ }^{213}$.

Uno de los ejemplos aludidos para justificar la exclusión resulta especialmente elocuente, ya que el Tribunal no considera amparable cualquier atentado «a la libre circulación de personas» ${ }^{214}$ realizado «con anterioridad a la Constitución». Es lógico que si alguien fuera encerrado en un almacén hace más de veinte años y, después de la Constitución, siguiera viendo impedida su libre circulación, mereceria amparo. El problema es, pues, si no se sigue hoy impidiendo en un remoto almacén de la Costa del Sol la libre comunicación artística de uno de nuestros más prestigiosos escultores.

Quizá por ello el Tribunal —si bien meramente a efectos discursivos- se anima a plantear la posibilidad de entender «el almacenamiento de las piezas desmontadas» como un hecho «realmente presente, con plena actualidad", lo cual parece darnos opción a recuperar la dimensión comunicativa de la creación artística. La respuesta a esta mínima dosis de riesgo que el Tribunal se concede no deja de resultar sorprendente. La vulneración "se habría producido el 28 de diciembre de 1978" y el recurso ha de considerarse en consecuencia extemporáneo ${ }^{215}$. Bromas de santoral aparte, la perplejidad es inevitable. O el almacenamiento no implica lesión "actual» apreciable después de diciembre de 1965 o, si la implica, lo hará indefinidamente, lo mismo el 28 o el 29 de diciembre de 1978, que el 18 de

213 Ibidem - (nota 203), p. 468ab. Es inevitable evocar aquí una anterior sentencia - la $7 / 83$ de 14 de febrero- que contó con un voto particular del magistrado Diez PICAzo; éste argumentaba, en relación a los derechos fundamentales en juego, que cmientras la lesión subsista, la prescripción no puede comenzar a contarse», contra el parecer mayoritario expresado por TOMAS VALIENTE, que admitía la prescripción de la acción, aunque por fortuna - casual o no- el plazo al que se acoge con no poco artificio permitió en aquella circunstancia otorgar el amparo — «BJC» 1983(23) pp. 237 y ss. Dada la querencia huidiza de la sentencia que venimos comentando no es fácil calibrar el alcance del silencio que el magistrado entonces discrepante ha guardado en esta ocasión.

214 Ibidem fundamento jurídico tercero - (nota 20), p. 468a.

215 Por transcurso del plazo de veinte dias a contar desde el 15 de julio de 1980 , según señaló el propio Tribunal —ibidem fundamento jurídico 4 (nota 203), p. 468b. “Confundir el plazo para ir al amparo constitucional con el plazo para ejercitar la acción civil de que ese amparo es subsidiario resulta un error grueso" dictamina E. GARCIA DE ENTERRIA - Pablo Serrano... (nota 37 ), p. 32 b. 
marzo de 1987 en que se está firmando tan Ilamativa afirmación. La lesión permaneceria; lo único que abre la vigencia constitucional es el sobrevenido comienzo - que no final- de su relevancia antijurídica.

\section{Un pintor toma el relevo}

La sentencia del Tribunal Constitucional pone un final feliz al tenaz esfuerzo del escultor Pablo Serrano por perfilar la protección de los derechos de los autores; pero, en los mismos dias en que parece esfumarse en el Congreso de los Diputados la esperanza de un eco legislativo que haga fecunda su brega, el pintor Antonio Sistiaga se ve empujado a tomar el relevo ${ }^{216}$. El restaurante que albergaba su monumental óleo de más de diecisiete metros se convierte en local para oficinas. Los nuevos ocupantes, demasiado ajetreados quizá para ser sensibles a la comunicación artística, deciden descuartizar la obra, enmarcando - a modo de lápida conmemorativa - el trozo de ella que, casualmente, exhibía la firma del autor. La pintura destinada a evocar "Las cuatro estaciones» se veía traumáticamente reducida a escueto parte meteorológico, situado - para mayor incomodo de su autor-en la proximidad de los servicios.

Nos encontramos ante una dimensión diversa de la lesión a la creatividad artística. Desde una perspectiva en dos tiempos, nadie ha impedido a Sistiaga pintar libremente un cuadro donde no se pone el sol. Es el resultado lo que se ha visto descuartizado; pero esto sólo podría afectar a derechos subjetivos que tengan fundamento en una ley ordinaria. Desde otra perspectiva, Sistiaga abrió una comunicación artística que ahora "se perpetúa», modificada radicalmente por los «autores» de la fechoria, que afectan así radicalmente a su libertad para plantear los términos de esa relación con los destinatarios de su creatividad artística. Ante ellos Sistiaga aparece ahora como «autor» de un parte meteorológico; de ahi que con todo derecho - fundamental - exija se prohiba toda exhibición (comunicativa) de algo distinto a lo que creó.

La demanda se presenta en solicitud de la protección jurisdiccional abierta por la ley 62/78, por entender incluidos los derechos del autor en el artículo 20.1.b) de la Constitución. A ello opondrán los demandados la inadecuación de dicho procedimiento, de acuerdo con la sentencia del Tri-

:218 La demanda se presenta ante el Juzgado de 1." Instancia $n .^{\circ} 9$ de Madrid el 16 de febrero de 1987, cuatro dias después de que el debate de totalidad del proyecto dé ocasión a exponer en el Congreso los problemas planteados por el caso Serrano. El 18 de marzo se firmará la sentencia del Tribunal Constitucional (publicada el 14 de abril). El 9 de abril firmó la Ponencia su Informe sobre las enmiendas al proyecto. El 4 de mayo emite la Secretaría General del Congreso su Informe negativo sobre el carácter orgánico del proyecto; los dias 12 y 13 se debate éste en Comisión, llegando el 21 al Pleno su vertiente penal ya desglosada en proyecto paralelo; nueve dias después se dicta sentencia sobre el caso Sistiaga. 
bunal Supremo de 9 de diciembre de 1985. Queda, pues, replanteado el viejo debate, suscribiendo el Minsterio Fiscal postura desestimatoria, por entender - como en su dia el Tribunal Supremo- que no se trataba de "proteger un derecho fundamental de la persona, sino el derecho moral de autor, nacido con la creación de la obra" ${ }^{217}$.

Nos encontramos ante un ilustrativo caso práctico de la cuestión debatida. Su núcleo se perfila con nitidez. Si se entiende la libre creación cómo una "facultad esencial de la personalidad», a la que serian ajenos unos derechos del autor entendidos como «derecho material sobre la obra creada», habria que concluir la «inadecuación de procedimiento»; si, por el contrario, los derechos del autor se consideran «consustanciales a su derecho a la creación artística, es claro que la via procesal elegida es correcta» ${ }^{218}$. Ante "la indefinición y ambigüedad existente en nuestro ordenamiento jurídico, que impide pronunciarse con certeza acerca de la naturaleza de los derechos" del autor, el juez decide acudir a unos peculiares antecedentes legislativos que se están gestando en esos mismos días: un proyecto de ley que por desgracia presenta también, a su juicio, «ambigüedades e indefiniciones». La Exposición de motivos no contribuye a disiparlas y, aunque la carencia de carácter orgánico del proyecto debe entenderse como pista negativa, la consulta elevada a la Mesa del Congreso para pronunciarse al respecto -pendiente aún, en su opinión de respuesta- deja la solución abierta. La conclusión, proyecto en mano, es que «el Legislador no se ha definido acerca de si el derecho fundamental a la producción y creación literaria, artística, científica y técnica es distinto del derecho de autor» o si éste le es «connatural» ${ }^{219}$.

Ante la indefinición del proyecto, resurge el hado fatal que parece condenar a refugiarse en opinones minoritarias a cualquier fundamentación de la constitucionalidad de tales derechos. Ayer fue un voto particular, hoy nos vemos remitidos a una enmienda - la 194 de la Agrupación del PDP al articulo 123-que suscita el carácter fundamental de los citados derechos. Lleno de optimismo - debido sin duda a su parco conocimiento de la cotidianeidad parlamentaria- el juez apunta la posibilidad de que a lo largo del debate «el legislador declarase que determinadas facultades del derecho de autor integran su derecho fundamental a la producción y creación literaria»; ante esta eventualidad, denegar la protección solicitada implicaría el «riesgo» ${ }^{220}$ de debilitar la efectiva tutela de sus derechos.

\footnotetext{
217 Sentencia de 30 de mayo de 1987. Antecedente de hecho sexto y Fundamento de derecho primero - (nota 113), pp. 5 a y $7 \mathrm{~b}$.

${ }_{218}$ Ibidem fundamento de derecho sexto -(nota 113), p. 12. Se reproduce el debate de la sentencia de 9 de diciembre de 1985 entre la mayoria del Tribunal y un voto particular que aqui se calífica de «muy razonado" - fundamento de derecho segundo in fine -(nota 113), pp. $12 b, 8 b$ y $12 a$. $8 b$ y $12 a$

219 Ibidem fundamentos de derecho sexto, tercero in fine y quinto -(nota 113), pp. 12b,

${ }_{220}$ Ibidem fundamentos de derecho quinto y sexto - (nota 113), pp. 11b y 13a.
} 
El juez desconoce el enigmático pronunciamiento emitido dos meses antes por el Tribunal Constitucional. Tras formular la obligada cábala al respecto, lo deja - sin duda inintencionadamente - en evidencia por contraste con su propia actitud. El dictamen puede resumirse en dos palabras: el Tribunal Constitucional "elude definirse»; "no asume» el planteamiento favorable a la constitucionalidad de los derechos del autor, que pone en boca del demandante, «sin que, obviamente, tampoco lo rechace». Y ahora viene el contraste. Buscando la interpretación más favorable al artículo 24,1 de la Constitución -que su propio Tribunal habría dejado abandonado en un pliegue de aquella sentencia - y de acuerdo con el artículo 11,3 de la Ley Orgánica del Poder Judicial que lo desarrolla, prefiere «entrar a resolver sobre las pretensiones que se formulan, que desestimarlas por motivos formales» ${ }^{221}$. Al fin un juez, llevado por su afán de hacer real y efectiva la protección que la Constitución proporciona a los derechos fundamentales, decide llegar al fondo.

\section{Horizonte incierto}

El conjunto de problemas básicos acumulados emplazaba a nuestros legisladores ante una responsabilidad ${ }^{222}$ que no podían soslayar. La vieja ley centenaria había abordado, a su modo, con más decisión el carácter fundamental de los derechos del autor; si los disfrazó de «propiedad» fue precisamente para garantizarles el máximo rango, aunque su monismo patrimonialista se verá pronto superado. La Constitución ofrecía una espléndida oportunidad para, repitiendo el ejemplo portugués, asumir planteamientos hoy internacionalmente reconocidos. Su debate fue más expresivo que su letra, dentro del ambiente de apresurado desaliño de un laborioso consenso. La inhibición de la nueva ley a la hora de abordarlos marca una perspectiva tendencialmente negativa, si tal silencio se entiende como exclusión ${ }^{223}$. Si los jueces se venian quejando de falta de apoyo legal para poder satisfacer pretensiones plausibles, no parece tras la nueva ley la probabilidad de que «la jurisprudencia del Tribunal Supremo, en reiteradas

${ }^{221}$ Ibidem fundamentos de derecho tercero y sexto - (nota 113), pp. 8a y 12b. En consecuencia, declara en su fallo "vulnerado el derecho moral del demandante», prohibe «la restauración de dicha obra pictórica durante la vida del sr. Sistiaga", prohibe por igual plazo que "en cualquie forma", incluso en el propio domicilio del propietario, se exhiba" el cuadro o sus restos y - «al no haber existido daño moral alguno» - desestima la petición de indemnización. Es fácil recordar que la única alusión a los derechos morales en el artículo 125 de la nueva ley es la relativa a indemnización por daño moral, por lo que poca eficacia hubiera mostrado en tan llamativo caso. El pronunciamiento encuentra eco en los últimos escarceos del debate $-P-69$ (nota 161), p. 4.170a.

222 Resaltada en el propio debate _-P-30 (nota 8), p. 1.710a.

${ }^{223}$ Al respecto $C-128$ (nota 9 ), p. $4.811 \mathrm{~b}$. 
sentencias, acogiese la doctrina sostenida por el voto particular» ${ }^{224}$ que discrepó de su último pronunciamiento prelegal.

La negación de rango orgánico a la nueva ley no deja de tener su fuerza, por la vía de una argumentación «a contrario», según se insiste desde las sedes más variadas ${ }^{225}$. ¿Qué alcance concreto debe darse a tal actitud? ¿Habria que entender que la Mesa del Congreso hizo suyo el razonamiento del Informe de su Secretaría General? En tal caso, se habría resuelto la cuestión estableciendo la conexión con el artículo 33, como fundamento de las diversas formas de «propiedad", incluida la «intelectual»; no falta resquicio en el debate para apoyar esta hipótesis ${ }^{226}$. Pero, aun dándola por buena, cabría siempre preguntar dónde se fundamentan unos derechos del autor que sólo desde el paleomonismo patrimonialista cabe encerrar integramente en tales esquemas. El dualismo que el proyecto decía suscribir, invita a la búsqueda de un nuevo fundamento para los derechos personales, que no estaria sino en el artículo 20.

Aun admitiendo la tesis del doble fundamento, sigue en pie la piedra de escándalo de la falta de carácter orgánico de los artículos relativos a los derechos «morales». La única vía de salida sería acogerse al «desarrollo indirecto" a que se alude en el debate ${ }^{227}$. Si entendemos por indirecto remoto, cabria admitir que el artículo 20 acoge el núcleo básico de los derechos «morales» del autor y deja abierta para su protección la vía del artículo 53,2, representada aún por la ley 62/78. La nueva ley se limitaría a recoger aspectos coyunturales de esos derechos, lo que explicaría su deficiente protección de los básicos; por considerarlos cubiertos por los cauces antedichos, evocados en el artículo 123 y su «sin perjuicio de otras acciones que le correspondan». Restan, sin embargo, dos fuentes de duda. La redacción del artículo 14 de la nueva ley contempla de modo más básico

${ }^{224}$ Sentencia del 30 de mayo de 1987, fundamento de derecho sexto - (nota 113), p. 13 a.

${ }^{225}$ En la doctrina, N. PÉrez de CAStro deriva de ello, bien a su pesar, consecuencias contrarias al carácter fundamental de los derechos del autor, incluso en la version restrictiva que suscribe El derecho de propiedad... (nota 24), p. 225. En el Fundamento de derecho quinto de la sentencia antes citada se apunta también que, én contra del propio parecer - de no rectificarse tal planteamiento durante el debate del proyecto- "se debe entender que no constituye ya desarrollo del derecho fundamental" - (nota 113), p. 10b. La mayoria parlamentaria trasladará reiteradamente a la Mesa del Congreso, por ella dominada, la responsabilidad -C-131 (nota 59), p. 4.955a y P-69 (nota 161), p. 4.169b- mientras la oposición dramatiza sobre el particular invocando a PECES BARBA - P-30, p. 1.706b y P-69 (nota 161), p. 4.170a.

${ }_{226}$ Se plantea primero como «reductio ad absurdum», antes de anunciar que «la inhibición se va a entender como una toma de postura»-C-131 (nota 59), pp. $4.953 \mathrm{~b}$ y $4.954 \mathrm{~b}$. Ante la presión argumental, el portavoz de la mayoría acaba concediendo tal consecuencia, aunque con convicción aparentemente escasa -ibidem pp. 4.956 b y $4.956 a$.

227 C-128 (nota 9), pp. 4.811a y 4.812a: "puede haber recurso de amparo siempre y cuando lo que se viole no sean cuestiones sobre el desarrollo de los derechos de autor o de la propiedad intelectual» sino la producción artistica o intelectual «in fieri». 
que coyuntural el núcleo de los derechos «morales» ${ }^{228}$; por otra parte, si admitimos a los derechos del autor un fundamento en el artículo 20, los cánones hermenéuticos del artículo 10,2 de la Constitución obligan a tener en cuenta la alusión de los documentos de Naciones Unidas a «intereses morales y materiales", dificultando la restricción de tal fundamento a uno sólo de los aspectos en juego.

La peripecia del pintor Sistiaga puede acabar resultando tan poco fructífera como la del escultor Serrano. Recurrida en casación la sentencia del Juzgado, el Tribunal Supremo habrá de examinar una fundamentación marcadamente coyuntural, cuyos puntos de apoyo se han venido abajo: el dictamen sobre el carácter orgánico, que ya se habia producido cuando se celebra la vista pública ${ }^{229}$, resulta negativo y la enmienda 194 también habría resultado rechazada antes de esa fecha. Tendria, pues, que aportar fundamentos diversos para iniciar esa serie de sentencias capaces de consolidar una doctrina que margine la sentencia de 9 de diciembre de 1985, para enlazar con su voto particular.

Sigue abierta la posibilidad de que otros casos similares lleven al planteamiento de un recurso de amparo, presentado en tiempo y forma, que obligaria al Tribunal Constitucional a abordar derechamente la cuestión, al no poder excusar su inhibición en «extemporaneidad» alguna ${ }^{230}$. En tal supuesto, sería deseable un pronunciamiento lo más explícito y comprehensivo que tal vía permita, para proyectar al fin algo de claridad sobre un problema que parece, hasta el momento, escogido como caso práctico para un concurso de indefinición y ambigüedad.

${ }^{228}$ La sentencia de 30 de mayo de 1987 señala, por ejemplo, cómo el artículo 14, 4. de la nueva ley habria de revestir, en tal caso, carácter orgánico - (nota 113), p. 11a.

${ }^{229}$ La vista pública tiene lugar el 25 de mayo de 1987 y la sentencia se firma el 30 del mismo mes, mientras que el dia 9 -BOCG Serie A, n. ${ }^{\circ} 14-9$ se dio publicidad al Dictamen de la Mesa del Congreso que el día 5 había calificado el proyecto como de ley ordinaria. También la enmienda aludida se había debatido y rechazado el dia 13 - C-131 (nota 59), pp. 4.953 y ss.

.230 Tal eventualidad se contempla en el debate, en alusión a «la última batalla del famoso caso Pablo Serrano, que está todavia por disputar" - C-131 (nota 59), p. 4.954ab. 